ROGÉRIO LAURIA MARÇAL TUCCI

\title{
PRORROGAÇÃO COMPULSÓRIA DOS CONTRATOS DE LONGA DURAÇÃO
}

\begin{abstract}
Dissertação apresentada à Banca Examinadora do Programa de Pós-Graduação em Direito, da Faculdade de Direito da Universidade de São Paulo, como exigência parcial para obtenção do título de Mestre em Direito, na área de concentração Direito Civil, sob a orientação do Professor Associado Dr. José Fernando Simão.
\end{abstract}

UNIVERSIDADE DE SÃO PAULO

FACULDADE DE DIREITO

SÃO PAULO

2015 


\section{Ficha catalográfica:}

Tucci, Rogério Lauria Marçal

Prorrogação compulsória dos contratos de longa duração / Rogério Lauria Marçal Tucci ; orientador José Fernando Simão -- São Paulo, 2015.

173

Dissertação (Mestrado - Programa de Pós-Graduação em Direito Civil) - Faculdade de Direito, Universidade de São Paulo, 2015.

1. Direito Civil. 2. Contratos. 3. Resilição. 4. Denúncia. 5. Abuso do direito. I. Simão, José Fernando, orient. II. Título. 
Banca examinadora: 


\section{RESUMO}

O tema desenvolvido guarda pertinência com a denúncia unilateral do contrato, a qual só deve produzir efeitos depois de transcorrido prazo compatível com eventuais investimentos consideráveis realizados pela contraparte, a teor do art. 473, par. ún., do Código Civil. Sendo assim, a pesquisa foi iniciada com premissas teóricas atinentes à liberdade contratual e suas vicissitudes em distintos momentos históricos. Esclarecido que a liberdade contratual deve ser sopesada com a intervenção Estatal para otimizar o desenvolvimento econômico e o bem-estar social, o trabalho demonstra, inicialmente, a coerência da mencionada norma em meio ao paradigma contemporâneo dominante. Em seguida, foram apresentadas reflexões para explicar a finalidade da inserção do dispositivo legal no ordenamento positivo. Com intuito de vedar o abuso de poder econômico, a norma foi introduzida especificamente para coibir o exercício abusivo do direito de resilição. Sendo este o escopo da norma, a primeira parte do trabalho ofereceu subsídios para justificar porque cabe ao juiz impor a prorrogação contratual, quando o denunciante não respeitar prazos compatíveis com os investimentos empreendidos pela outra parte. Já quanto à segunda parte, foram lançadas elucubrações sobre os distintos aspectos das relações contratuais duradouras. Nesse ponto, foram apontadas importantes contribuições doutrinárias a respeito da influência do aspecto temporal sobre as relações contínuas e, ainda, perspectivas da análise econômica do direito, além da abordagem relacional do contrato. Restando elucidado que a prorrogação do contrato pode (e deve) ser imposta pelo intérprete, na última e terceira parte deste trabalho, é proposta uma interpretação sistemática e axiológica da norma do art. 473, par. ún., do Código Civil.

palavras chave: contrato de longa duração - denúncia abusiva - prorrogação compulsória

Rogério Lauria Marçal Tucci. Prorrogação compulsória dos contratos de longa duração. Mestrado. Faculdade de Direito, Universidade de São Paulo, São Paulo, 5 de janeiro de 2015. 


\begin{abstract}
The subject developed concerns the unilateral termination of the contract, which shall only take effect after certain length compatible with sizeable investments made by the counterparty, as set forth in Article 473, sole paragraph, of the Civil Code. Therefore, the research began with theoretical premises regarding the contractual freedom and its variations in different historical moments. Once clarified that the contractual freedom must be counterbalanced by governmental intervention in order to optimize economic development and social well-being, the study initially demonstrates the consistency of the aforesaid rule in the midst of the currently reigning paradigm. In addition, some reflections were presented to explain the purpose of the insertion of the provision in the written body of laws. Seeking to prevent the abuse of economic power, the ruling was created specifically to diminish abusive use of the right to terminate. Given the scope of the provision, the first part of the paper sustained why should the judge extent the length of the notice when the terminating party fails to comply with a compatible term taken into account the investments carried out by the other party. As for the second part, there are musings about different aspects of long-term contracts. Important contributions from legal doctrine were pointed out concerning the influence of time on long-term relationships, and furthermore on perspectives of the economic analysis of Law, besides the relational approach to the contract. As it becomes plain that the extension of a contract may be, or rather ought to be, imposed by the judge, on the third and last part of the dissertation, it is proposed a systematic and axiological interpretation of the ruling set forth by Article 473, sole paragraph, of the Civil Code.
\end{abstract}

Key-words: long-term contract - abusive termination - compulsory extension

Rogério Lauria Marçal Tucci. Compulsory Extension of Long-term Contracts. Master. Faculty of Law, University of São Paulo, São Paulo, January 5th, 2015. 


\section{SUMÁRIO}

Objeto do trabalho e noções introdutórias . .8

\section{PARTE I - PREMISSAS TEÓRICAS: PRORROGAÇÃO CONTRATUAL COMO

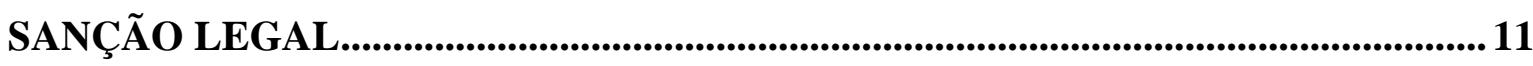

Capítulo 1 - Teoria geral do contrato - do paradigma clássico à modernidade ...................... 11

Capítulo 2 - Ilicitude da resilição unilateral: boa-fé objetiva e abuso de direito ................... 27

Capítulo 3 - Fundamento dogmático do art. 473, par. ún., do Código Civil........................... 36

Considerações conclusivas da parte I: a prorrogação como sanção legal................................43

\section{PARTE II - CONTRATOS DE LONGA DURAÇÃO: CARACTERÍSTICAS

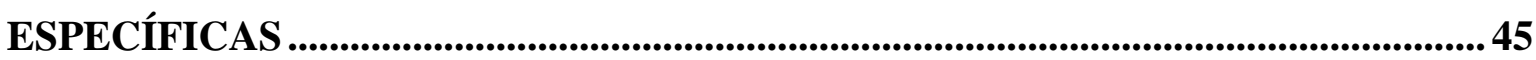

Capítulo 1 - Contratos de longa duração e sua extinção ............................................................ 45

Capítulo 2 - Reflexões sobre a influência do tempo no regime dos contratos........................53

Capítulo 3 - Implicações do paradigma contratual moderno e das novas teorias contratuais sobre as relações de longa duração .........................................................................59

Seção I - Análise econômica do direito ..............................................................................59

Seção II - Análise econômica do direito no âmbito do contrato ................................................61

a) o "paradoxo da indenização" e os incentivos ao adimplemento........................................64

b) economia dos custos de transação ...................................................................................................... 71

c) teoria dos contratos incompletos ..................................................................................... 81

Seção III - Abordagem relacional do contrato ..........................................................................8 87

Considerações conclusivas da parte II: a noção de resilição unilateral abusiva em contratos

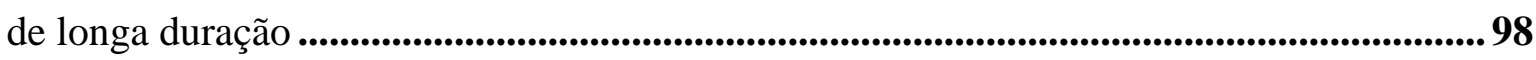




\section{PARTE III - PRORROGAÇÃO COMPULSÓRIA DOS CONTRATOS DE LONGA}

DURAÇÃO: INTERPRETAÇÃO DO ART. 473, PAR. ÚN., DO CÓDIGO CIVIL 100

Capítulo 1 - A "natureza do contrato" 100

Seção I - Aplicação da norma segundo os grandes grupos contratuais 100

Seção II - Alteração do comportamento das partes durante a relação contratual ....

Seção III - Obrigação de renovação ínsita às relações de longa duração. 122

Seção IV - Custos de transação obstantes da renovação expressa do contrato 128

Seção V - Ineficiência da multa contratual e o aviso prévio 131

Capítulo 2 - Os "investimentos consideráveis" 136

Seção I - Interesse contratual positivo e interesse contratual negativo 138

Seção II - Simetria dos investimentos com as declarações negociais 147

Seção III - Investimentos realizados para contingência de externalidades 150

Capítulo 3 - O "prazo compatível” 153

Capítulo 4 - Contrato compulsoriamente prorrogado 157

CONSIDERAÇÕES CONCLUSIVAS 162

Referências bibliográficas 166 


\section{OBJETO DO TRABALHO E NOÇÕES INTRODUTÓRIAS}

A presente dissertação tem como objetivo o estudo aprofundado das razões e fundamentos que justificam a prorrogação dos efeitos da denúncia unilateral dos contratos de longa duração, nas hipóteses em que são verificados os chamados "investimentos consideráveis”, segundo o disposto no art. 473, par. ún., do Código Civil.

Para tanto, será necessária a apresentação de reflexões sobre os contratos de longa duração; a noção de abusividade do direito de resilição unilateral; a natureza e o vulto dos “investimentos consideráveis"; e, por fim, a relação entre o investimento efetivado e o prazo de prorrogação.

O trabalho desenvolvido poderá servir tanto às partes negociantes, quando da formação do contrato ao estipular cláusulas relativas à possibilidade de resilição unilateral contratual, quanto ao juiz, se instaurado o litígio, para auxiliá-lo a definir o tempo de prorrogação mais adequado, segundo as vicissitudes circunstanciais de um ato ilícito levado à sua cognição.

Pelo viés negocial, o presente estudo prestar-se-á como subsídio para celebração de cláusulas contratuais sobre a resilição unilateral ou, mais especificamente, acerca do período entre a denúncia contatual e o momento de cessação dos efeitos do contrato, como, por exemplo, nos casos de relações contínuas por prazo indeterminado.

Além disto, também em relação aos contratos de longa duração com prazo estipulado, a interpretação sistemática da norma do art. 473, par. ún., do Código Civil pode servir como fundamento para cláusulas que dizem respeito ao tempo de aviso prévio ${ }^{1}$, ou também para compatibilização de uma cláusula penal.

Já em sede contenciosa, a problemática inicial submetida ao intérprete pode ser abreviada na seguinte indagação: por que prolongar contratos em um sistema garantidor da reparação civil integral em caso de ilícito contratual?

A resposta a esta indagação é precisamente o desiderato da primeira das três principais partes deste trabalho. Esclareça-se, desde já, que esta dissertação almeja explicar

\footnotetext{
${ }^{1}$ A expressão "aviso prévio" no Brasil é, via de regra, utilizada nas relações trabalhistas. Nesta dissertação, todavia, a exemplo do que se observa em Portugal, a expressão "aviso prévio" designa o período entre o momento da denúncia contratual e a data em que o contrato estará efetivamente resilido.
} 
porque a prorrogação compulsória deve ser considerada pelo intérprete como uma sanção legal para evitar a ruptura abusiva do contrato.

Ademais, se a possibilidade de o Judiciário impor a prorrogação contratual for afastada, a interpretação da norma diria respeito unicamente a uma obrigação ex vi legis consubstanciada na compatibilização da denúncia unilateral do contrato e os investimentos realizados pelas partes.

Eventual demanda atinente à resilição unilateral estaria resguardada exclusivamente pela responsabilidade civil indenitária (se evidenciado o ilícito, é claro), a exemplo, aliás, de alguns arestos proferidos pelo Superior Tribunal de Justiça².

Ao mesmo tempo, portanto, que as ponderações aqui oferecidas colaboram para uma sistematização da propagação dos efeitos de denúncia unilateral, há o objetivo de fornecer fundamento para justificar porque a prorrogação dos contratos deve ser caracterizada como sanção legal legítima.

Já a segunda parte do trabalho será desenvolvida para apresentar peculiaridades específicas sobre a noção de abuso de direito nos casos de relação contratual de longa duração. $\mathrm{O}$ abuso de direito da denúncia unilateral guarda pertinência com relevantes aspectos das relações contratuais duradouras, mormente com a contribuição de modernas abordagens sobre a teoria contratual.

${ }^{2}$ É o que se denota do acórdão da 4 a Turma, proferido no julgamento do Recurso Especial n. 534.105-MT, de relatoria do Ministro CÉSAR ASFOR ROCHA: "CIVIL E PROCESSO CIVIL. CONCESSÃO COMERCIAL. LEI $N^{\circ}$ 6.729/79. RESCISÃO DE CONTRATO. LIMINAR PARA CONTINUIDADE DA CONCESSÃO. AUSENACIA DE PRESSUPOSTO. É princípio básico do direito contratual de relações continuativas que nenhum vínculo é eterno, não podendo nem mesmo o Poder Judiciário impor a sua continuidade quando uma das partes já manifestou a sua vontade de nela não mais prosseguir, sendo certo que, eventualmente caracterizado o abuso da rescisão, por isso responderá quem o tiver praticado, mas tudo será resolvido no plano indenizatório. Ausência do fumus boni juris, pressuposto indispensável para concessão de liminar. Recurso conhecido e provido". Nesse mesmo sentido, no julgamento do Recurso Especial n. 200.856-SE, da $3^{\mathrm{a}}$ Turma e relatado pelo Ministro WALDEMAR ZVEITER, lê-se que: "PROCESSO CIVIL. AÇÃO CAUTELAR. MEDIDA LIMINAR. INTERVENÇÃO JUDICIAL EM CONTRATO. Medida liminar, garantindo a continuidade de contrato já denunciado por uma das partes, ao fundamento de que a resilição deixou de observar as formalidades nele previstas para esse efeito. Infração contratual que - acaso existente - se resolve em indenização por perdas e danos, não justificando a manutenção do contrato contra a vontade de uma das partes. Recurso especial conhecido e provido". E, ainda, no Agravo Regimental no Agravo de Instrumento n. 988.736-SP, relatado pelo Ministro ALDIR PASSARINHO JR., sendo oportuna a seguinte transcrição: "É princípio do direito contratual de relações continuativas que nenhum vínculo é eterno. Se uma das partes manifestou sua vontade de rescindir o contrato, não pode o Poder Judiciário impor a sua continuidade.". 
Compreender o desvio da finalidade econômico social do direito de resilir é algo significativamente particular no contexto dos contratos de longa duração.

Quando perfilhadas as considerações sobre a prorrogação compulsória como sanção legal a evitar a resilição abusiva, a terceira e última parte visa a propor uma interpretação sistemática do art. 473, par. ún., do Código Civil a fim de desvendar os elementos instituídos no dispositivo legal como a "natureza do contrato", os "investimentos consideráveis" e o "prazo compatível” de prorrogação.

Cumpre salientar que não há na doutrina brasileira pesquisa mais aprofundada sobre a natureza jurídica dos chamados "investimentos consideráveis" capazes de fundamentar a extensão do termo contratual, tampouco acerca de quais critérios devem ser levados em consideração para a fixação do "prazo compatível".

Finalmente, também serão traçadas diferenças no entendimento da temática à luz dos grandes grupos contratuais: contratos tradicionais, contratos por adesão e contratos de consumo e, outrossim, segundo a classificação em contratos de lucro e existenciais.

Antes das conclusões gerais do estudo, impõe-se o estudo da relação contratual, porventura, compulsoriamente prorrogada para averiguar se tal fenômeno pode alterar dogmas contratuais, principalmente no que toca ao adimplemento.

Estas, em suma, as considerações introdutórias da presente dissertação. 


\section{PARTE I - PREMISSAS TEÓRICAS: PRORROGAÇÃO CONTRATUAL COMO SANÇÃO LEGAL}

\section{CAPÍTULO 1 - TEORIA GERAL DO CONTRATO - DO PARADIGMA CLÁSSICO À MODERNIDADE}

As trocas livres e voluntárias de bens e serviços revelam um importante, se não o mais relevante, instrumento de eficiência econômica de uma sociedade. Dois motivos são naturais e intuitivos. Primeiramente, porque é por meio das trocas que a comunidade prospera na medida em que seus consumidores podem satisfazer seus interesses. No mais, em uma sociedade em que há escassez de certos recursos, por força das trocas, é possível a alocação destes recursos simetricamente às escolhas dos consumidores ${ }^{3}$.

Tome-se uma digressão sobre uma sociedade que desconheça por completo todo e qualquer contrato celebrado por seus cidadãos, sendo a alocação de recursos realizada a esmo. Inevitavelmente, não haverá recursos para satisfação deste ou daquele interesse consumerista, o que também impedirá a possibilidade de lucro daqueles que ali ou aqui alocariam certo recurso.

No mais, pela eficácia obrigatória dos contratos, a alocação de recursos mediante as trocas pode ser realizada da maneira mais eficiente. Por exemplo, um fazendeiro pretende vender uma cabeça de gado que lhe custou $\mathrm{R} \$ 300,00$. Existem dois compradores interessados, o primeiro oferece $\mathrm{R} \$ 500,00$ à vista; o segundo oferece $\mathrm{R} \$$ 1.000,00, mas para pagamento em trinta dias. Não fosse a possibilidade de execução de um contrato, a escolha tenderia para a alocação de recursos mais imediata e não pela mais eficiente ${ }^{4}$.

Observa-se, portanto, que o fim precípuo das trocas (dos contratos) é duplo: satisfazer o interesse dos cidadãos e possibilitar a alocação de recursos forma adequada e suficiente.

Ocorre que simples trocas não são suficientes para a consecução de tais objetivos, uma vez que contratos instantâneos guardam papel cada vez menos acentuado

\footnotetext{
${ }^{3}$ P. S. ATIYAH, An Introduction to the Law of Contract, $5^{\mathrm{a}}$ ed., Oxford, Clarendon Press, 1995, p. 4-5.

${ }^{4}$ Cf. exemplo de R. A. Posner, Economic Analysis of Law, $5^{\mathrm{a}}$ ed., Nova York, Aspen Law \& Business, 1998, p. 102.
} 
no contexto social moderno. É necessário, destarte, o planejamento consensual para futuras trocas. Neste sentido, a confiança assume papel essencial no campo contratual, pois se uma parte não confiar no cumprimento da obrigação da outra, o sistema não mais se sustenta ${ }^{5}$.

Poder-se-ia afirmar que a confiança é desnecessária na medida em que são cominadas em lei sanções para quem descumpre a obrigação assumida, inclusive sendo possível a execução forçada específica. A confiança restaria como algo despiciendo e estranho à satisfação do interesse de certo credor. Este raciocínio, embora lógico, é equivocado. É imperioso lembrar que a execução do contrato como previsto e devidamente planejado é algo da mais genuína importância para a prosperidade social ${ }^{6}$.

Os séculos XVIII e XIX foram marcados pela grande proliferação dos contratos, principalmente com a ascensão da burguesia e declínio do Absolutismo. Os princípios contratuais que norteavam as relações privadas, tidos como tradicionais ou clássicos, são, sem dúvida, essenciais para a compreensão da moderna disciplina dos direitos contratuais ${ }^{7}$. Reputa-se necessária uma noção da evolução principiológica no período imediatamente anterior, quando o jusnaturalismo e a filosofia do laissez-faire serviram como base de todo um sistema cujo principal protagonista era a autonomia da vontade ${ }^{8}$.

Para o intérprete do século XVIII, o maior símbolo de autonomia da vontade era a ampla propriedade privada, outrora duramente conquistada. Se a propriedade do homem era ampla e inalienável, nada mais racional do que a total autonomia para dela dispor. Não obstante, à época, doutrinas paternalistas ainda exerciam forte influência e

\footnotetext{
${ }^{5}$ P. S. ATIYAH, An Introduction ... cit., p. 5.

${ }^{6}$ Lembrando-se da afirmação de C. V. Couto E SiLVA: "A obrigação é um processo, vale dizer, dirige-se ao adimplemento, para satisfazer o interesse do credor." (A obrigação como processo, $1^{a}$ (re)edição, São Paulo, FGV, 2006, p. 167).

${ }^{7}$ Cf. R. P. MACEDO JR., Contratos relacionais e defesa do consumidor, $2^{\mathrm{a}}$ ed., São Paulo, Ed. RT, 2007, p. 46: "Entender e conceber uma nova teoria contratual que ajude a explicar o direito contratual do passado e permita reconstruir o direito de maneira a transformá-lo é o desafio cada vez mais urgente e é também uma das características mais evidentes do debate atual europeu ocidental e norte-americano sobre teoria contratual. Contudo, se todo direito contratual associa-se de maneira intima a uma determinada ordem de produção e de mercado, é necessário, antes de mais nada, pensar a ordem de mercado na qual vai se formando o novo direito contratual. É preciso identificar quais são as mudanças ocorridas nesta ordem de mercado que vão afetar o regime das relações contratuais".
}

${ }^{8}$ P. S. ATIYAH, An Introduction ... cit., p. 7. 
obstavam a proteção para as classes menos favorecidas, em uma sociedade ainda caracterizada por estamentos ${ }^{9}$.

Como é sabido, a influência paternalista é completamente vencida pela filosofia do laissez-faire. O Estado adota a política de menor intervenção possível no domínio privado ${ }^{10}$.

Desde a passagem do século XVIII para o XIX, a exaltação da liberdade individual é pressuposto cultural para a fundação do modelo socioeconômico observado na maior parte do mundo ocidental. O modelo do antigo regime é paulatinamente substituído.

No tocante à disciplina dos contratos, o intérprete só precisava se ater à resolução das consequências advindas da violação (o que inseria consequências práticas ao modelo econômico-social jamais vistas ${ }^{11}$ ). De resto, os efeitos das disposições contratuais eram completamente estranhos ao Estado.

Vale a ressalva, contudo, de que é equivocado concluir que os oitocentistas menos se importavam com justiça do que o cidadão moderno. Aos olhos de cada revolucionário, o liberalismo era a expressão máxima da justiça. A massa, longe do ideal paternalista, era perfeitamente capaz de proteger seus próprios interesses "quer no mercado ou nos palanques ${ }^{, 12}$.

Pois bem, pela ótica liberal, era possível escolher tanto a pessoa com que se contratava quanto o teor das disposições, sem maior atenção ao poder de barganha de cada

\footnotetext{
${ }^{9}$ P. S. ATIYAH, An Introduction...cit., p. 8.

${ }^{10}$ Cf. P.S. ATIYAH, An Introduction... cit., p. 8: "In general the law was not concerned with the fairness or justice of the outcome, and paternalistic ideas came to be thought of as old-fashioned. The judges were not even greatly concerned with the possibility that a contract might not be in the public interest. So the function of contract law was merely to assist one of the contracting parties when the other broke the rules of the game and defaulted in the performance of his contractual obligations. The judge was just a sort of umpire whose job it was to respond to the appeal 'How's that?' when something went wrong.". Em tradução livre: "Em geral, a lei não estava preocupada com a justiça do resultado e ideias paternalistas eram descartadas por serem reputadas antigas. Os Juízes sequer se preocupavam com a possibilidade de um contrato não coadunar-se com o interesse público. Portanto a função do direito contratual era meramente assistir uma das partes contratantes quando a outra quebrava as regras do jogo e inadimplia suas obrigações contratuais. O Juiz era simplesmente um tipo de árbitro cujo trabalho era responder ao apelo 'Como assim?' quando algo desse errado".

${ }^{11}$ Cf. V. RopPO, Il contratto, Milão, Giuffrè, 2001, p. 37.

${ }^{12}$ Em tradução livre de P. S. ATIYAH, An Introduction... cit., p. 9: "whether in the market place or at the hustings".
} 
parte. Bem é verdade que o liberalismo jamais atingiu aqueles indistintamente vulneráveis como os menores, dementes, ébrios, etc. De resto, fosse qualquer conflito, a premissa era a de que ambas as partes estavam em pé de igualdade, pois haviam celebrado aquele pacto em pleno gozo da liberdade.

É neste contexto que ficou conhecida a célebre expressão cunhada por HENRY S. MAINE “do status ao contrato”, símbolo da mudança social do antigo regime à promoção da burguesia ${ }^{13}$.

Ocorre que, ainda no século XIX, a presunção de igualdade do poder de barganha revelou-se uma premissa enganosa. Muito não demorou a se perceber que, por exemplo, o empregado estava submetido ao poder do empregador ou que o consumidor era refém do vendedor, o qual se dobrava à vontade do fornecedor, e assim por diante, sendo a ferramenta de exploração precisamente o contrato ${ }^{14}$.

Desde a ascensão do Estado Liberal, o contrato se proliferava como instrumento de autoafirmação da classe burguesa, que lhe garantia o acesso à propriedade $\mathrm{e}$ à obtenção de mão-de-obra, mas, em decorrência do aumento progressivo de trocas e negócios jurídicos já sensivelmente mais complexos, o modelo liberal rapidamente se revelou inadequado.

Se, por um lado, o liberalismo libertava o indivíduo dos vínculos feudais e do Antigo Regime, garantindo a igualdade formal e a livre iniciativa, de outro, criava um sistema defensor dos interesses particulares da classe burguesa, justificado pela bandeira da autonomia individual. Ao permitir a liberdade irrestrita e garantir a execução dos contratos em qualquer hipótese, o Estado Liberal tornou o contrato um instrumento de controle manejado pela burguesia.

Pode-se dizer que o período da plena liberdade contratual é melhor situado entre 1770 e 1870 . No último quarto do século XIX, inicia-se um gradual e longo declínio da primazia da autonomia da vontade. Três fatores podem ser identificados como as influências capitais na destruição do paradigma contratual clássico: a proliferação dos contratos de massa, geralmente, por adesão; a evolução do conceito de obrigação

\footnotetext{
${ }^{13} \mathrm{~V}$., a respeito, V. RopPO, Il contratto... cit., p. 37.

${ }^{14}$ P. S. AtIYAH, An Introduction...cit., p. 14.
} 
afastando-o da intenção das partes (o que no Brasil é costumeiramente tratado como perspectiva dinâmica da obrigação ${ }^{15}$ ); e, por fim, a promoção da tutela protetiva do consumidor.

Os contratos por adesão nascem em um contexto de revolução industrial e aumento estrondoso das relações de consumo. A vontade do contratante passa a ser exclusivamente a opção de celebrar o contrato ou não. Seja pela velocidade com que muitas das relações quotidianas passam a ser resolvidas, seja pelo crescente desconhecimento que o cidadão passa a ter sobre aquele ou este serviço, os contratos por adesão crescem de uma forma notória. Paralelamente a este crescimento, há a noção de que os contratos por adesão são necessários à sociedade moderna, pois permitem a economia de tempo, conflitos e custos de transação ${ }^{16}$.

Outro aspecto decisivo na alteração do velho paradigma, na esteira da necessidade de proteção aos menos favorecidos, foi o afastamento da ideia de que o objeto obrigacional poderia ser definido exclusivamente pela vontade das partes exarada no contrato. ATIYAH lembra a demanda em que a mudança interpretativa ficou clara no Reino Unido pelo aresto promulgado no julgamento do caso Davis Contractors v. Farehan UDC pela Casa dos Lordes no qual, em suma, foi decidido que mais importante do que a declaração aposta na cláusula do contrato era a intenção que razoavelmente podia se esperar das partes, guardadas as circunstâncias do negócio ${ }^{17}$.

A proteção ao consumidor como um dos principais interesses sociais e, por isto, um dos destacados objetivos do Estado é o último fator decisivo para a superação do paradigma contratual clássico. Sobre o tema, já asseverava MiguEl REALE: “Aliás, o cuidado no sentido de preservar a liberdade contratual é tão grande que a orientação prevalecente não é no sentido de controle do contrato, mas sim no de fortalecer a parte fraca para que ela mesma possa exercer o direito de contratar" ${ }^{, 18}$.

\footnotetext{
${ }^{15}$ V., por todos, C. V. do CouTO E SILVA, A obrigação... cit., principalmente, p. 63-97.

${ }^{16}$ P. S. ATIYAH, An Introduction ...cit., p. 17-18.

${ }^{17}$ An Introduction ... cit., p. 21.

${ }^{18}$ M. REALE, Resilição dos contratos por tempo indeterminado, in Questões de Direito Privado, São Paulo, Saraiva, 1997, p. 37.
} 
Ao tutelar com maior veemência o interesse dos consumidores, naturalmente os contratos de consumo são regulados de forma distinta, seja proibindo certas disposições, seja criando novas obrigações àquele que se vê em uma relação de consumo. A limitação à liberdade incide, portanto, de duas formas: impedindo o fornecedor de certo comportamento e, ainda, impondo o dever de determinada conduta.

Sobre o diploma consumerista, lembra ClÁUdiA LIMA MARQUES que, para a proteção do direito de escolha do consumidor e de sua autonomia racional, reconhece-se, entre outros, "um direito mais forte de informação"19 consubstanciado em vários dispositivos, além de um direito de reflexão permitindo-se o arrependimento imotivado (para os contratos celebrados fora do estabelecimento comercial).

Alguns outros eventos também podem ser tidos como determinantes quando se pensa no declínio da liberdade de escolha, ou liberdade contratual. ATIYAH discorre sobre três aspectos ulteriores deste fenômeno. A complexidade contratual demandando maior ingerência do intérprete na hora do julgamento, restando a atividade de simplesmente executar o acordado insuficiente para a satisfação do interesse dos jurisdicionados; um crescente ceticismo com as benesses do ideal liberal, o que para o autor tem seu início principalmente na década de 1870, quando os monopólios já assumiam o papel de protagonistas no mercado; e, o principal motivo, uma mudança dos próprios valores políticos, especialmente pelo reconhecimento "do problema das externalidades", a exemplo da poluição, sujeira, aglomeração de pessoas e doenças, enfim, custos adicionais da Revolução Industrial impostos a terceiros. Neste sentido, pelas externalidades, o interesse social podia obstar a troca ${ }^{20}$.

Ainda, muito mais simples do que a noção de externalidade, a liberdade extrema de escolha é um dos principais fatores que começavam a ocasionar um fenômeno até então não conhecido pelo homem, a desigualdade massificada injusta.

Pela primeira vez o cidadão percebia uma quantidade de pessoas em necessidade e reputava tal situação injusta. Na segunda metade do século XIX, nada justificava (nobreza, linhagem) a vantagem de um em detrimento do prejuízo de tantos

${ }^{19}$ C. L. MARQUES, Contratos no Código de Defesa do Consumidor - o novo regime das relações contratuais, $6^{\mathrm{a}}$ ed., São Paulo, Ed. RT, 2011, p. 271. V., no mesmo sentido, R. P. MACEDO JÚNIOR, Contratos... cit., p. 46.

${ }^{20}$ Cf. P. S. ATIYAH, An Introduction ... cit., p. 19-20. 
outros $^{21}$. Há a percepção de que sem o auxílio da lei, a exploração pelas partes mais poderosas seria irreprimível. A liberdade de escolha passava a ser a forma de instrumentalização da vontade dos influentes.

Só neste cenário é que a proibição desta ou daquela cláusula ou a necessidade de fazer constar certa previsão começam a integrar, ainda que modo tímido, o conteúdo das leis ${ }^{22}$.

Com efeito, o século XX foi marcado pela crescente intervenção estatal no domínio dos contratos. O paradigma neoclássico, portanto, necessita lidar com novas formas importantes para a eficiência econômica das trocas como os contratos por adesão, a genérica obrigação de informar, mecanismos de reequilíbrio para os contratos de longa duração e, ademais, o ainda crescente aumento do intervencionismo estatal ${ }^{23}$.

Ocorre que no atual momento, há quem diga que a intervenção estatal limitadora da liberdade contratual já deve ser repensada, visto que produz indesejáveis efeitos para a sociedade de consumo.

21 P. S. ATIYAH, An Introduction... cit., p. 20: "The weak and the poor, the vulnerable and the exploited, were felt to be in need of protection by the law. If left to make their own contracts, it came to be increasingly thought, they would inevitably be worsted by rich and powerful contracting parties on the other side. So the law was called in aid in a multitude of ways to interfere in contracts, prohibiting some kinds of contracts, some kinds of contractual terms, or insisting that other contracts should confer rights on one or other party which were not actually contained in the contract.". Em tradução livre: "Os fracos e os pobres, os vulneráveis e os explorados, foram identificados em necessidade de proteção da Lei. Se cogitada a possibilidade de realizarem seus próprios contratos, começa-se a pensar que inevitavelmente seriam sobrepujados por partes contratantes ricas e poderosas do outro lado. Portanto, a Lei veio a socorrê-los em múltiplas maneiras para interferir nos contratos, proibindo alguns tipos de contratos, alguns tipos de cláusulas contratuais, ou insistindo que outros contratos devessem conferir direitos a uma ou outra parte, o que não tinha sido, de fato, contido no contrato".

${ }^{22}$ Também é lembrado por P. S. ATIYAH, dissertando sobre o declínio da liberdade de escolha, que a partir do início do século XX, além do controle de cláusulas, são criadas leis com hipóteses em que o cidadão é obrigado a contratar, algo completamente contraditório se pensado pelo paradigma clássico em que celebrar um contrato nada mais era do que o resultado da liberdade de escolha, verbis: "Other changes also began to take place with the law of contract had grapple with. (...) For instance, in the 1950s a tenant of business premises was first given, subject to certain conditions, a statutory right to a new lease on the expiry of his old one. The landlord was (and indeed remains today) legally obliged to grant the new lease. To the traditional contract lawyer an obligation to enter into a contract seems very like a contradiction in terms, for a contract has traditionally been seen as the outcome of a free choice.”. (An Introduction ... cit., p. 22). Em tradução livre: "Outras mudanças também começaram a ocorrer e desafiar o direito contratual. ( ... ) Por exemplo, na década de 1950, a um inquilino de locação comercial, foi dado, pela primeira vez, sujeito a determinadas condições, o direito legal a uma nova locação quando do vencimento da antiga. O senhorio era (e, na verdade, permanece até hoje) legalmente obrigado a conceder o novo contrato. Para o advogado tradicional, a obrigação de celebrar um contrato parece muito com uma contradição em termos, pois um contrato tradicionalmente tem sido visto como o resultado de uma escolha livre".

${ }^{23}$ Cf. R. P. MACEDO JR., Contratos... cit., p. 46. 
AтIYAH, em meados da década de 1990, já advertia que na Inglaterra, em cuja experiência jurídica as normas de direito contratual são eminentemente criadas pelo sistema do common law, não se dá a devida atenção para uma nova mudança do paradigma dada a alteração no cenário mundial ocidental, ocasionada pela ascensão do neoliberalismo desde a década de $1980^{24}$.

Segundo as lições do mesmo autor, o paulatino declínio da liberdade contratual desde o fim do século XIX deve ser objeto de nova avaliação. Em uma metáfora: o pêndulo que afastava a liberdade contratual do paradigma pode ter alterado seu curso, e, atualmente, tende na direção da maior liberdade contratual segundo a ótica neoliberalista ${ }^{25}$.

$\mathrm{Na}$ busca dos fundamentos das alterações que vêm ocorrendo no campo contratual, é afirmado que a primeira razão é nitidamente política. A liberdade de escolha passa a ser bem-vinda na medida em que há necessidade de maior competitividade entre agentes. Mais sucesso para aqueles que desempenham seu papel com sucesso e menos ajuda aos que sucumbem.

As privatizações de grandes empresas, públicas, a exemplo do que ocorreu no Brasil da década de 1990, são lembradas como alterações macroeconômicas exatamente para a maior liberdade de escolha. Trocas que até então eram de competência pública e, por isto, de maior regulamentação, foram deslocadas para a iniciativa privada.

Quanto aos consumidores, dois aspectos são significativos: o primeiro que hoje ele está em melhor situação do que aquele cidadão vulnerável que o paternalismo do paradigma anterior almejava defender; já o segundo diz respeito à sólida economia com grande leque para suas escolhas. Neste sentido, a maior competição, além de mais justa, pode atender mais satisfatoriamente aos interesses do consumidor.

A par da motivação política, também é possível justificar a maior liberdade de escolha já que, modernamente, normas jurídicas são também amplamente estudadas pelo

\footnotetext{
${ }^{24}$ An Introduction ... cit., p. 27.

${ }^{25}$ V., no mesmo sentido, G. ALPA, I principi generali, Milão, Giuffrè, 1993, p. 327-331.
} 
seu efeito econômico. Neste sentido, a liberdade de escolha é primordial para a eficiência econômica da sociedade ${ }^{26}$.

Pode-se citar o exemplo de um proprietário de uma lanchonete que pagava aos seus funcionários menos do que o salário mínimo imposto por lei. Notificado pelas autoridades, o proprietário não pôde adequar sua folha salarial, preferindo o fechamento do estabelecimento. Os funcionários, que aceitavam as condições impostas, restaram desempregados. A fonte de renda para adequar o salário não mais subsistia e os consumidores perderam sua oportunidade de escolha.

ATTYAH ainda lembra que para obstar a liberdade ampla de escolha, a doutrina frequentemente aponta, como principal justificativa, o risco de disposições contratuais injustas em decorrência do desequilíbrio do poder de barganha. Neste contexto, atenta que, em um mercado genuinamente competitivo e funcionando bem, as distinções entre o poder de barganha não necessariamente implicarão prejuízos injustos, principalmente porque haverá mais opções de escolha ao consumidor ${ }^{27}$.

Sem dúvida, não se podem olvidar as ferramentas de regulação econômica, mas, somente quando e se houver um desvio da "saúde" econômica circunstancial ${ }^{28}$, no caso de monopólios, ou, ainda, quando se tratar de bens tangíveis essenciais, como, por exemplo, energia elétrica ou gás.

Ante esta explanação, conclui o mencionado autor que desde a década de 1980, o governo britânico tenta, ao menos no longo prazo, permitir novamente a liberdade contratual mais flexível em certos campos como, v. g., salário mínimo e controle de

\footnotetext{
26 Cf. P.S. AтIYAH, An introduction... cit., p. 29: "Subsidizing inefficient industries (for example) means that excessive resources are devoted to the production of things which consumers just do not want to buy at the real social cost at which they are produced. So also, laws such as used to exist for restricting the availability of consumer credit (minimum deposits, for instance) and exchange control laws are no longer acceptable to the government because they distort the free market. They have been repealed, therefore, and the area of freedom of contract has been correspondingly enlarged.". Em tradução livre: "Subsidiar indústrias ineficientes (por exemplo) significa que os recursos excessivos são dedicados à produção de coisas que os consumidores simplesmente não querem comprar ao real custo social em que são produzidas. Assim também, as Leis, como costumavam existir para restringir a disponibilidade de crédito ao consumo (depósitos mínimos, por exemplo) e as Leis de controle de câmbio já não são aceitáveis para o governo porque elas distorcem o mercado livre. Elas foram revogadas, portanto, e a área da liberdade de contrato foi proporcionalmente ampliada.".

${ }^{27}$ P.S. ATIYAH, An Introduction ... cit., p. 30.

${ }^{28}$ O que MACEDO JR. denomina falhas de mercado (Contratos relacionais... cit., p. 54-58).
} 
aluguéis. Quanto aos trabalhadores ou locatários em necessidade, é melhor ajudá-los de maneira direta e não de modo a impedir que a contratação ocorra conforme a competitividade circunstancial demandar ${ }^{29}$.

Sob outra perspectiva, ainda em defesa de uma maior liberdade contratual, ATTYAH se refere à massificação dos contratos por adesão, nos quais não há possibilidade de uma das partes definir as cláusulas que direcionarão os efeitos do negócio jurídico. Existem duas questões que devem ser analisadas de modo distinto: a "justiça procedimental" e a "justiça substancial". Quanto aos procedimentos, há a necessidade de intervenção para que seja mantido certo equilíbrio estrutural. A par disto, a substância da relação, o resultado produzido pelas previsões apostas, não deve ser vinculado a maior controle, baseada na crença de que, em prol de eficiência econômica, esta substância é regulada (justificada) estritamente pelo preço $^{30}$.

Assim sendo, é necessário lembrar que a escolha quanto à maior ou menor liberdade contratual depende de uma multiplicidade de critérios. Mesmo em ordenamentos que compartilham idênticos valores essenciais, observam-se variações significativas ${ }^{31}$.

Limitar a liberdade contratual não é tarefa simples. Raramente, a imposição de limites será taxativa, por meio de uma clara e objetiva norma preceptiva como nos casos em que há fixação de preço ou concessão de certa faculdade como a de redibir a coisa se evidenciado certo vício. A norma limitadora vai além da vedação de certa conduta. A tutela recai, na verdade, sobre o todo o conteúdo da relação negocial, de modo circunstancial,

\footnotetext{
${ }^{29}$ P. S. ATIYAH, An Introduction ... cit., p. 31.

${ }^{30}$ P. S. AtIYAH, An introduction... cit., p. 32. Vale a ressalva, como lembrado por J. S. RIBEIRO, de que as normas de maior ou menor limitação à liberdade de cada cidadão devem ser tomadas em respeito a fatores históricos e circunstanciais: "Vimos que o ordenamento jurídico retira poderes de autonormação aos privados quando não quer correr o risco de eles se traduzirem em actos negociais com um conteúdo lesivo de interesses que lhe incumbe tutelar. Quando assim é, o princípio da autodeterminação cede perante um outro princípio ou policy com ele conflituante. A extensão de um tal falta de prevalência depende, naturalmente, de decisões de política legislativa, condicionadas por factores históricos e por razões circunstanciais, por opções de base a nível de constituição político-econômica e pelos mutáveis objetivos que, dentro dela, os poderes públicos queiram estrutural ou conjunturalmente atingir" ( $O$ problema do contrato: as cláusulas contratuais gerais e o princípio da liberdade contratual, Coimbra, Almedina, 1999, p. 234).
}

${ }^{31}$ Cf. J. S. RIBEIRO, O problema... cit., p. 234. 
caso a caso. Se a execução de uma parte vai além ou fica aquém de certo standard típico e objetivo, invocado daquela norma, aí sim, haverá a inadmissibilidade da conduta ${ }^{32}$.

A liberdade contratual não é, ademais, extrínseca ao sistema jurídico. Tanto a autonomia de cada cidadão quanto os eventuais limites a esta autonomia derivam de uma fonte comum, qual seja o próprio sistema jurídico. Regular a liberdade contratual nada mais é do que optar (de modo sistemático) por uma forma de organização das relações sociais de trocas e cooperação ${ }^{33}$.

Já quanto às trocas, naturalmente, elas podem produzir uma variedade de efeitos, desejáveis ou não. Alguns deles podem ser atingidos (ou evitados) com a concessão de maior liberdade. De modo análogo, outras vezes, a imposição de limites é que produz (ou impede) determinado efeito.

Também sobre o novo paradigma contratual, VINCENZO ROPPO ${ }^{34}$ enfatiza que atualmente há uma preponderância de pressões de mercado (econômicas) no lugar em que, no passado, era ocupado por finalidade exclusivamente política. Não se quer dizer que a economia de mercado dita completamente o ritmo do paradigma jurídico. Subsiste, por certo, a persecução dos objetivos políticos.

O principal exemplo da moderna ponderação entre economia e política no campo jurídico advém da crescente influência das Diretivas da Comunidade Europeia. A matéria-prima nas décadas de 70 e 80 era forjada ainda sobre um regime de sensíveis diferenças entre microssistemas.

A partir do fim do século XX, no entanto, há "um salto de qualidade” na legislação. As chamadas "leis de última geração" são criadas no âmbito de um cenário de supranacionalidade crescente e pressões convergentes para a maior uniformização de contratos com o intuito claro e específico de facilitar as relações entre os dois grandes protagonistas da nova ordem: o empresário e o consumidor ${ }^{35}$.

\footnotetext{
${ }^{32}$ J. S. RIBEIRO, O problema... cit., p. 235.

${ }^{33}$ V., a respeito, J. S. RIBEIRO, O problema... cit., p. 240-242.

${ }^{34}$ Il contratto del duemila, $3^{\mathrm{a}}$ ed., Turim, G. Giappichelli, 2011, p. 6-7.

35 V. R. VAnZella, O contrato, de Enzo a Vincenzo, in Revista Direito GV, v. 1, n. 2, São Paulo, jundez/2005, p. 223.
} 
Neste sentido, uma das críticas de ATIYAH diz respeito às modernas legislações europeias relativas à concessão de crédito ao consumidor demasiadamente protetivas e paternalistas, implicando altos custos para os fornecedores (repassados aos consumidores). Outro efeito indesejável de tais leis é a proteção a consumidores oportunistas e irresponsáveis ensejando custos aos demais cidadãos honestos ${ }^{36}$.

Observe-se, por oportuno, que no Brasil esta discussão está atualmente em destaque, pois em que pese o fato de o Código de Defesa do Consumidor ser um diploma intrinsecamente principiológico ${ }^{37}$, e, por isto, apto a solucionar uma variedade de conflitos, o Poder Legislativo houve por bem instituir, em 2 de dezembro de 2010, uma comissão de juristas $^{38}$ para atualizar e aperfeiçoar o Código de Defesa do Consumidor. Dentre os principais temas a serem focados encontra-se o denominado superendividamento do consumidor $^{39}$.

Sobre a uniformização de normas supranacionais, VINCENZO ROPPO também demonstra certo receio ${ }^{40}$. A despeito da maior qualidade da legislação supranacional, a influência dos objetivos políticos pode gerar consequências prejudiciais, pois " $a$ ênfase

\footnotetext{
${ }^{36}$ P.S. ATIYAH, An Introduction... cit., p. 33.

${ }^{37}$ V., a respeito, S. P. MARÇAL e R. J. CURY, O comércio eletrônico e o Código de Defesa do Consumidor, in Revista do Advogado - AASP (direito e internet), ano 32, n. 115, São Paulo, abril/2012, p. 141.
}

${ }^{38}$ A Comissão de Juristas foi presidida pelo Ministro HERMAN BENJAMIN, e integrada por CLÁUDIA LIMA MARQues, relatora dos trabalhos, AdA Pellegrini Grinover, Kazuo Watanabe, LeOnardo Roscoe Bessa e Roberto Augusto CAstellanos PFEIFFER.

39 Desta iniciativa, além do Projeto de Lei do Senado n. 282/2012 sobre o superendividamento, foram elaborados projetos de lei acerca do comércio eletrônico (PLS n. 281/2012) e das ações coletivas (PLS n. 283/2012), todos publicados no Diário do Senado Federal de 3 de agosto de 2012.

Sobre o Projeto de Lei do Senado n. 282/2012, foram propostas algumas dezenas de normas que impõem ao fornecedor dever de informar detalhadamente o consumidor sobre a operação pretendida, inclusive com esclarecimento quanto ao custo efetivo total e os elementos que o compõe. Proibição ao fornecedor da utilização de expressões consideradas agressivas como "sem juros", "taxa zero", "gratuito". Preservação do chamado "mínimo existencial", não podendo o débito superar $30 \%$ da renda do consumidor quando este previamente aprovar o modo de pagamento. Por fim, ainda há a previsão de um procedimento judicial para a conciliação e renegociação de dívidas do consumidor superendividado.

V., por todos, C. L. Marques e R. L. CaVallazi (coords.), Direitos do consumidor endividado, São Paulo, Ed. RT, 2006.

${ }^{40}$ Il contratto del... cit., principalmente p. 41-64. 
agora se dá, entretanto, nas consequências que o desarranjo do Estado-nação provoca nas técnicas contratuais tradicionais ${ }^{, 41}$.

A obra mais recente de VinCENZO RoPPO é, destarte, fundamental para reconhecer que o paradigma moderno padece de certas falhas na medida em que a internalização das escolhas políticas insertas nas Diretivas da Comunidade Europeia é, por vezes, efetivada de forma genérica e atabalhoada, deixando de lado a necessária assimilação cultural e a experiência jurídica de determinado país para adequar-se à ordem supranacional.

Ressalte-se, por outro lado, que a análise mais recente de ATTYAH demonstrando certa apreensão com a crescente intervenção estatal que, porventura, pode implicar, nos dias atuais, desnecessária proteção ao crédito do consumidor, pode ser repensada, pois, em última análise, a crise do sistema financeiro norte-americano de 2008 está umbilicalmente atrelada à falta de regulamentação dos derivativos financeiros, ou seja, o crédito ao consumidor pode estar desnecessariamente protegido ao mesmo tempo em que a larga concessão de crédito ao investidor acarretou a maior crise financeira mundial das últimas décadas ${ }^{42}$.

Sobre este ponto, duas ressalvas são de rigor. A primeira, é que as ponderações, positivas e negativas, sobre as Diretivas da Comunidade Europeia podem e devem ser incorporadas à realidade brasileira, pois, entre nós, o estudo delas- é, cada vez, mais notório e frequente, sendo conhecidas de todos os estudiosos do Direito Privado.

A segunda ressalva diz respeito exclusivamente ao presente trabalho, pois o estudo da prorrogação compulsória qualificada como sanção adequada em casos de abuso de direito não encontra obstáculos na legislação supranacional europeia. Pelo contrário, o art. 57 do Code de Contrats Européen contempla expressa previsão de que nas contratações por prazo indeterminado, o aviso prévio deve respeitar a natureza do contrato, os bons costumes ou a boa-fé: "Si dans les contrats à exécution continue ou périodique les parties n'ont pas fixé de terme final, chacune d'entre elles peut mettre terme au contrat à

\footnotetext{
${ }^{41}$ R. VANZELLA, $O$ contrato... cit., p. 223.

${ }^{42}$ V., por todos, I. MACNEIL, O novo contrato social (prefácio à edição brasileira), trad. The New Social Contract: An Inquiry into Modern Contractual Relations, New Haven, Yale University, 1980, trad. port. Alvamar de Campos Andrade Lampranelli, Rio de Janeiro, Elsevier, 2009, p. I-XXXVI.
} 
travers une communication adressée à l'autre partie en donnant um préavis qui soit conforme à la nature du contrat ou à la coutume, ou à la bonne foi ${ }^{, 43}$.

Outro exemplo emblemático das significativas mudanças do paradigma contratual no século XX é a evolução da doutrina de VINCENZO RoPPO ${ }^{44}$.

Segundo as lições desse autor, a despeito do modo acelerado pelo qual os Estados buscam a internalização do direito supranacional, a verdadeira crise do paradigma contratual está consubstanciada na realidade de que a nova ordem globalizada, cada vez mais, exige um contrato cuja flexibilidade sobreponha-se aos valores da certeza e estabilidade, preconizados pelo corolário principiológico pacta sunt servanda, de modo a privilegiar a garantia da melhor alocação de recursos.

No âmbito de uma sociedade globalizada, a flexibilidade contratual passível de gerar maior eficiência econômica adquire papel mais relevante do que a segurança jurídica advinda da estabilidade contratual ${ }^{45}$.

Tecidas estas considerações, é possível concluir que a liberdade contratual e a intervenção estatal no domínio dos contratos são valores que no Estado de Direito sempre buscaram adaptação entre si, em prol de uma justa eficiência do sistema econômico. Houve

${ }^{43}$ Em tradução livre: "Se em contratos de execução contínua ou periódica, as partes não fixaram termo final, qualquer uma dentre elas pode por fim ao contrato através de uma comunicação endereçada à outra parte dando um aviso prévio conforme a natureza do contrato, ou aos costumes, ou à boa-fé”.

${ }^{44}$ R. VANZELLA, inclusive, lembra-se o fato de que, na década de 1970, o autor apresentava-se à comunidade acadêmica como ENZO e, mais recentemente, como VINCENZO, o que seria atribuído às profundas modificações realizadas em sua obra sobre direito dos contratos: "O Roppo da década de 70 do século XX vai sendo, dessarte, superado pelo Roppo do século XXI, o que se deflagra alegoricamente pela mudança de seu prenome, ao menos no seio de suas obras, para "Vincenzo". Com isso, seu livro Il contratto daqueles anos 70 é substituído por outro homônimo, mas muitíssimo alterado tanto no plano de exposição e na extensão dos temas abordados. Feito tomo do Trattato di diritto privato cuidado por G. Iudica-P. Zatti, o novo Il contratto é acrescido pelo pequeniníssimo volume do Il contratto del duemila, publicado pouco depois cujos três ensaios servem como sua introdução. $O$ que fica de Enzo é a mesma preocupação com o substrato socioeconômico em relação às normas jurídicas postas, seus mútuos influxos, o mesmo modelo de compreensão do instituto jurídico contratual lastreado no devir histórico, com sérias reservas à linha da continuidade acrítica, tão comum a alguns civilistas. Mas o enfoque das transformações dos objetivos políticos do direito dos contratos deixa de ocupar o primeiro plano de sua análise para ceder lugar ao estudo imediato de questões dogmáticas advindas de um modo diferente de regulação jurídica, que redefine o direito dos contratos e o próprio instituto contratual” (R. VANZELLA, O contrato... cit., p. 222-223).

${ }^{45}$ Cf. V. RopPO, Il contratto del... cit., p. 4: "Ma quale figura del contratto? Il contratto dell'economia e della società globalizzate è un contratto in cui l'esigenza della flessibilità fa premio sui valori della certezza e della stabilità". Em tradução livre: "Mas qual figura do contrato? O contrato da economia e sociedade globalizadas é um contrato no qual a exigência da flexibilidade supera os valores da certeza e estabilidade". V. também R. VANZELLA, $O$ contrato... cit., p. 223. 
momentos de harmonia, mas também de choques frontais, ocasiões em que estiveram em jogo ideologias políticas e a dogmática jurídica.

A prorrogação compulsória dos contratos também deve ser analisada no cenário desta perspectiva: não se pode a priori refutar a disposição legal por violação à liberdade contratual, mesmo porque esta nunca foi absoluta. Pelo contrário, é preciso compreender a lógica do parágrafo único do art. 473 do Código Civil para interpretá-lo de modo sistemático no ordenamento, ou seja, se a norma pode gerar eficiência econômica e, ainda, diminuir injustiça por meio de barreiras à exploração da parte contratual mais fraca, não há o que fundamente a preocupação inicial de alguns estudiosos, insinuando, sem maiores elucidações, que a prorrogação compulsória não poderia ser recepcionada por inaceitável contradição à liberdade contratual.

No mesmo sentido, JACQUES AZÉMA, dissertando sobre o que denominou "declínio do direito de resilição unilateral", observa que, a despeito de o contrato por prazo indeterminado ser conceitualmente vínculo no qual é permitida a denúncia unilateral, modernamente existem limites ao direito de resilição. Em decorrência da vedação geral ao abuso de direito ou de violação a deveres instituídos pela cláusula geral de boa-fé, a resilição unilateral pode ser repudiada pelo sistema, ainda que em relações por prazo indeterminado ${ }^{46}$.

Destarte, se a resilição unilateral está sujeita a limites, a prorrogação compulsória do contrato pode ser considerada uma reação do sistema tal qual a responsabilização por perdas e danos impingidos à contraparte, contenção que se coaduna perfeitamente ao paradigma moderno que prestigia normas contratuais de modo a permitir a busca mais eficiente de alocação de recursos.

A questão que se coloca é a seguinte: quando a melhor alocação de recursos para uma parte estiver consubstanciada no inadimplemento ou ruptura do contrato, pode a parte ser liberada do vínculo contratual, desde que proceda ao ressarcimento à contraparte? Pode uma parte denunciar um contrato duradouro ao arrepio da boa-fé e dos bons costumes, desde que seja condenada ao pagamento de indenização pelos prejuízos causados em decorrência de sua conduta abusiva?

${ }^{46}$ La durée des contrats successifs, Paris, L.G.D.J., 1969, p. 257. 
Certamente não. A melhor alocação de recursos é um fim que só encontra guarida quando sopesado à obrigatoriedade inerente aos contratos e não apenas por diretrizes políticas similares ao antigo Estado paternalista, mas sim pelas forças do próprio mercado que demandam a circulação de riquezas com certa flexibilidade, mas limitada por uma desejada estabilidade, na medida em que o sistema possui expectativa de que os contratos ainda sejam compatíveis à confiança neles depositada.

Por estas razões, o presente estudo se direciona, em imediata sequencia, à demonstrar como os limites à resilição unilateral, contemplados em nossa legislação, podem ser interpretados, a fim de que seja efetivada a prorrogação compulsória do contrato, caracterizada como sanção legal existente paralelamente à responsabilidade civil indenitária em caso de abuso do direito do denunciante ${ }^{47}$.

São, contudo, indispensáveis algumas explicações preambulares a esclarecer quando a denúncia unilateral deverá ser considerada abusiva.

Para tanto, o próximo Capítulo aspira exatamente à articulação de algumas importantes ideias que já foram expostas sobre o abuso de direito, visando a justificar como a resilição unilateral pode revestir-se de ilicitude.

${ }^{47}$ V., nesse sentido, J. AZEMA, La durée... cit., p. 174-175; e A. L. LABORDERIE, La pérennité contractuelle, Paris, L.G.D.J., 2005, p. 501-502. 


\section{CAPÍTULO 2 - ILICITUDE DA RESILIÇÃO UNILATERAL: BOA-FÉ OBJETIVA E ABUSO DE DIREITO}

No ordenamento jurídico brasileiro, a ilicitude decorre de dois tipos de conduta. Aquela quando, a teor do art. 186 do Código Civil, o agente culposamente viola direito e causa danos a outrem, cometendo, assim, ilícito aquiliano; ou, ainda, quando o titular de um direito excede o respectivo fim econômico ou social, extrapolando os limites impostos pela boa-fé ou pelos bons costumes, ou seja, abusa de seu direito (art. 187 do Código Civil).

Na seara contratual, ademais, há ainda a responsabilidade por perdas e danos quando não cumprida a prestação (art. 389 do Código Civil).

Sobre a figura do abuso de direito, vale dizer, que seu reconhecimento não está adstrito a qualquer base científica, $i$. e., sua conceituação como instituto jurídico autônomo derivou de uma necessidade sistemática de coibir condutas antijurídicas de forma mais clara.

As primeiras menções à figura do abuso de direito são de procedência francesa não porque o Código Napoleônico recolheu tal categoria, mas porque o instituto primeiro surgiu em arestos dos tribunais franceses com o objetivo de justificar a ilicitude de certas condutas, as quais não desafiavam a concepção lógico-formal da norma, mas afastavam-se de sua perspectiva axiológica-material.

O exercício abusivo de um direito qualifica-se, por excelência, como a conduta lícita quanto à forma, mas distante de seu escopo material ${ }^{48}$.

Forte nesta constatação, não se pode concluir que a recepção da categoria "abuso de direito" no ordenamento cria ulteriores formas de ilicitude. O ato ilícito por exercício abusivo de um direito, sem embargo do art. 187 do Código Civil, poderia muito

\footnotetext{
${ }^{48}$ V., por todos, F. A. CUNHA DE SÁ, Abuso do direito, Coimbra, Almedina, 1973 (reimpressão de 1997), p. 634: "se concluiu estar perante um comportamento que é materialmente estranho ao exercício do direito subjectivo ou da diversa prerrogativa jurídica individual: só que enquanto a ilicitude é, desde logo, directa e frontal violação dos limites formais do direito ou da prerrogativa em causa, já o acto abusivo finge a aparência estrutural desse mesmo direito ou prerrogativa, assim encobrindo a violação dos limites formais da sua intenção normativa. Por isso, quer a ilicitude quer o abuso do direito são em si mesmos, substancialmente, actuação sem direito, em carência do direito, mau grado ali se tratar da ultrapassagem dos limites lógico-formais de uma determinada prerrogativa individual e aqui do excesso ou desrespeito dos respectivos limites axiológicos materiais".
} 
bem ser inferido de um ilícito aquiliano clássico, a exemplo do art. $186^{49}$. Também por isso não são admissíveis consequências distintas entre os dois tipos de ato ilícito. Daí, a coerência do Código Civil brasileiro ao explicitar as consequências da conduta ilícita em único dispositivo (art. 927), a despeito de os atos serem qualificados tanto no art. 186 quanto no art. 187.

De mais a mais, é por isso que EDUARDO JORDÃo conclui que o conceito de abuso de direito adequa-se à sistemática do Direito Privado com dupla finalidade: simplificar a interpretação jurídica e estabelecer limites claros emergentes do ordenamento $^{50}$.

Nem mesmo os exemplos encontrados nas fontes romanas, como a aemulatio, a exceptio doli e nas relações entre vizinhos, são suficientes para reconhecer, ainda que de forma embrionária, a concepção moderna do instituto. As antigas definições estavam atreladas ao ânimo (emulativo) de quem exercia o direito subjetivo.

O abuso de direito é modernamente idealizado independentemente do elemento volitivo, ou tampouco de aferição de culpa. Não se deve admitir a imperiosidade da prova de culpa, sob pena de amainar sensivelmente a importância do instituto, apesar do entendimento de CUNHA DE SÁ, que defende a necessidade de culpa do agente por inobservância do "dever de não abusar" lecionar que só se admite o abuso de direito quando o agente divorciar-se da "conduta que legalmente teria de observar" ${ }^{\prime 52}$.

À exceção dessa minoritária corrente doutrinária, é considerável a maioria que defende a objetivação do abuso de direito na linha do enunciado n. 37 da Primeira Jornada do Centro de Estudos Judiciários do Conselho da Justiça Federal: "Art. 187: A

49 Tanto é assim que, ainda hoje, os direitos italiano e suíço não adotam o abuso de direito como cláusula geral e aberta. (v., a respeito, A. M. R. Menezes Cordeiro, Da boa fé no Direito Civil, v. 2, Coimbra, Almedina, 1984, p. 685-707).

${ }^{50}$ Repensando a teoria do abuso de direito, Salvador, Juspodivm, 2006, p. 138.

${ }^{51}$ Abuso... cit., p. 637-646. Segundo as lições de CUNHA DE SÁ, o abuso de direito só poderia ser concebido quando evidenciada a inobservância do dever de não abusar. A dificuldade, nos limites desta pesquisa, para adotar a posição de CUNHA DE SÁ é identificar a culpa quando atrelada ao a um dever negativo. A culpa do agente pois ele "não deveria abusar" é, ao que parece, muito similar ao reconhecimento da conduta abusiva por parâmetros estritamente objetivos, prescindíveis do aferimento de culpa.

52 Comentários ao novo Código Civil, v. 3, t. 2, coord. Sálvio de Figueiredo Teixeira, Rio de Janeiro, Forense, 2007, p. 128. 
responsabilidade civil decorrente do abuso de direito independe de culpa e fundamenta-se somente no critério objetivo-finalístico".

A principal dificuldade em adotar-se a posição pela qual é exigida a culpa como requisito do ato abusivo é prescrever o dever inobservado, pois o raciocínio de CunHA de SÁ ou Humberto TheOdoro JR. implica uma conclusão paradoxal: há abuso, pois o agente não deveria abusar.

Mais adequada é a conclusão de que, quando o agente excede os limites do direito, assume o risco de responder por eventuais danos causados a outrem, sendo necessário, é claro, prova do nexo de causalidade.

Ademais, abuso de direito e boa-fé são categorias jurídicas independentes e não conflitantes, mas com pontos de aproximação ${ }^{53}$. A boa-fé exerce, dentre outras funções, a base para os limites de exercício de um direito. Já a figura do abuso do direito é uma vedação geral do sistema, cujos limites são definidos, de modo não exclusivo, pela boa$\mathrm{fé}^{54}$.

Feitas estas ilações, depreende-se que a resilição unilateral, a ensejar a sanção do art. 473, par. ún., do Código Civil, deve ser enquadrada como ato abusivo e, portanto, ilícito.

Observe-se, contudo, que se, por exemplo, certo contratante proceder à denúncia unilateral de uma relação na qual era proibida a extinção do vínculo de tal modo,

\footnotetext{
${ }^{53}$ V., por todos, A. M. R. Menezes CoRdeiro, Da boa fé... cit., principalmente p. 707-718 e 1.294: “ $A$ concretização jurisprudencial portuguesa do "abuso do direito" manifesta uma recepção progressiva da boa fé, enquanto factor de inadmissibilidade de certos exercícios, estando, ainda, algo incipiente. 84. Com factores materiais de disfuncionalidade no exercício de posições jurídicas surgem, através da boa-fé, vectores básicos do sistema como a protecção da confiança e a relevância da materialidade subjacente”.

54 V., a respeito, A. SCHREIBER, A proibição de comportamento contraditório, $3^{\mathrm{a}}$ ed., Rio de Janeiro, Renovar, 2012, p. 119: "Conclui-se, ao menos à luz do direito positivo brasileiro, que boa-fé objetiva e abuso do direito são conceitos autônomos, figuras distintas, mas não mutuamente excludentes, círculos secantes que se combinam naquele campo dos comportamentos tornados inadmissiveis (abusivos) por violação ao critério da boa-fé. Entre nós, portanto, é possível falar em abuso de direito por violação à boafé, sem que aí se esgotem todas as espécies de abuso, ou todas as funções da boa-fé”. No mesmo sentido, T. NEGREIROS, Teoria do contrato - novos paradigmas, Rio de Janeiro, Renovar, 2002, p. 140-141: "Prosseguindo na análise do princípio, passamos agora a analisar a função por última referida: a boa-fé objetiva como limite ou óbice ao exercício de direito subjetivos. A boa-fé está diretamente relacionada à teoria do abuso de direito nesta sua função de limitar ou mesmo impedir o exercício de direitos que emergem da relação contratual. (...) Diante da ordenação contratual, o princípio da boa-fé e a teoria do abuso de direito complementam-se (...)”.
} 
estará agindo, segundo o art. 389 do Código Civil, em evidente inadimplemento contratual. Não há exercício abusivo de direito, mas violação do direito da contraparte.

Ainda que o vínculo contratual seja forçadamente mantido em caso de inadimplemento contratual por denúncia proibida, não se estará diante da hipótese de prorrogação dos efeitos da denúncia, mas de execução específica do contrato, se o lesado decidir por bem utilizar a faculdade que lhe é atribuída pelo art. 475 do Código Civil.

Restando claro que a prorrogação dos efeitos de denúncia unilateral está adstrita ao abuso de direito, este trabalho deve concentrar-se nos limites que porventura caracterizam o exercício irregular do direito de resilir.

Logo, reputa-se necessário enfatizar que os três princípios cardeais do regime contratual: a autonomia privada, a força obrigatória dos contratos e a relatividade obrigacional, embora ainda prestigiados pelo sistema, adquiriram novos contornos com o surgimento dos princípios da boa-fé objetiva, do equilíbrio econômico e da função social dos contratos.

O princípio da boa-fé funciona como limitador da liberdade contratual. Verdadeiro critério de controle, se não o principal, da atuação dos contratantes. Modernamente, contudo, a atuação do princípio é promovida de forma mais abrangente. Além de exercer papel regulador, a boa-fé também funciona como meio de integração do conteúdo da obrigação. Cria deveres acessórios e de conduta. O campo funcional do princípio também passou a fundamentar a vedação ao abuso de direito ${ }^{55}$.

Estas funções, acima relembradas, demonstram que atualmente o princípio da boa-fé serve ao sistema com a dúplice função, impedindo determinadas condutas e exigindo outras.

O princípio da boa-fé desenrola, portanto, fonte criadora de condutas e, ao mesmo tempo, reguladora (impeditiva) de outras. Há, deste modo, uma alteração metodológica e normativa. "Em vez de actuar no interior de uma relação já constituída, modelando integrativa e restritivamente os procedimentos que as partes devem adoptar, na fase de execução, a boa-fé incide diretamente, neste campo, sobre as estipulações que

${ }^{55}$ J. S. RIBEIRO, O problema... cit., p. 542. 
se propõem determinar o conteúdo contratual "56. Exemplo desta mudança metodológica é o próprio art. 51 do Código de Defesa do Consumidor.

A evolução funcional da boa-fé não deve ser vista "como um desenvolvimento lógico e linear (...) a menos que se considere a boa-fé uma panaceia universal" compreensão deste fenômeno, é importante reconhecer que o critério do paradigma anterior (os bons costumes) era de certa estreiteza e rigidez ${ }^{58}$. Entendeu-se, assim, ante a insuficiência dos bons-costumes como critério de restrição ao conteúdo obrigacional, buscar um fundamento normativo para limitar à liberdade quanto a este conteúdo para uma composição desejada (justa) de interesses, inferidos logicamente do sistema ${ }^{59}$.

A boa-fé objetiva, portanto, é hoje a principal fonte reguladora dos direitos subjetivos. Os bons costumes, por sua vez, a despeito de ainda exercerem ampla influência sob o exercício de direitos, dificilmente são interpretados de forma divorciada da boa-fé.

Fosse a boa-fé objetiva critério único de vedação a condutas antijurídicas, não seria necessário dispor de outras normas que não a do art. 187 do Código Civil, ou seja, a boa-fé como limitadora do exercício de direito é relevada apenas uma de suas roupagens, a qual, nesta pesquisa, será primordial.

Ademais, este estudo deverá analisar de forma sistemática o que vem a ser a finalidade econômico-social do direito de resilição, ganhando contornos mais importantes quando proposta uma interpretação acerca do significado da expressão "investimentos consideráveis", para fim de protraimento do momento de eficácia da denúncia unilateral.

A título de introdução, esclareça-se que, em se tratando de resilição unilateral do contrato, não existe a fortiori uma definição legal de resilição unilateral abusiva. É

${ }^{56}$ J. S. RIBEIRO, O problema... cit., p. 550.

${ }^{57}$ J. S. RIBEIRO, O problema ... cit., p. 550.

${ }^{58}$ J. S. RIBEIRO, O problema... cit., p. 551: "Pouco abrangente, em demasia, quanto à previsão, sobretudo quanto conexionado ainda com o merecimento de um forte juízo de censura, esse critério mostrava-se excessivo e até contraproducente, quanto à estipulação, pois cominava, em princípio, a nulidade total, sem admitir correç̧ões flexiveis ao conteúdo do contrato".

${ }^{59}$ J. S. RiBEIRO, O problema... cit., p. 553. Segundo o autor, o entendimento é sintetizado em um famoso aresto do BGH de 1964: "Quem põe em vigor condições gerais dos contratos reivindica para si um exclusivo, no que respeita à conformação do conteúdo, a liberdade contratual. Está por isso obrigado, segundo a interesses de seus futuros parceiros contratuais. Se fizer apenas os seus próprios interesses, abusa da liberdade contratual. Nessa medida, a liberdade contratual é limitada pelo § 242 do BGB”. 
possível, contudo, apreender uma noção específica com o socorro à doutrina e à jurisprudência, como bem lembra JACQUES AZÉMA ${ }^{60}$.

Neste contexto, assevera esta doutrina que em França foram levadas em consideração duas teorias. A primeira, que guarda respeito exclusivamente ao eventual prejuízo que a contraparte pode incorrer com a resilição unilateral; e, a segunda, pela qual se condiciona a antijuridicidade a um comportamento objetivamente condenável ${ }^{61}$.

Como já adiantado, forte na vedação geral ao abuso de direito, a solução hodiernamente inclina-se para uma percepção mista pela qual só haverá responsabilidade pela resilição unilateral quando esta decorrer de conduta que objetivamente extrapole os limites do direito subjetivo (resilição) e cause danos à contraparte.

Finalmente, observe-se também que a disciplina imposta pelo art. 473, par. ún., do Código Civil, não deve ser considerada como absoluta novidade no ordenamento positivo brasileiro. Desde há muito, certos contratos de longa duração estiveram atrelados à impossibilidade de sua respectiva extinção neste ou naquele momento. A novel norma, contudo, estipula critério geral de prorrogação do vínculo quando a denúncia, embora possível, é efetivada em momento reprovável segundo circunstâncias específicas.

Sob a égide do Código Civil de 1916, não havia norma genérica para a conservação dos contratos em decorrência de verificação de investimentos consideráveis, mas o ordenamento posto já apresentava diversas hipóteses em que era previsto em lei prazo mínimo de vigência.

De modo semelhante à antiga codificação, não há, por exemplo, no ordenamento positivo espanhol norma genérica, mas tão somente disposições aplicáveis a contratos específicos. Não obstante, é pacífico que a denúncia unilateral não predispõe

${ }^{60}$ La durée...cit., p. 261.

${ }^{61}$ La durée...cit., p. 261. 
direito potestativo ilimitado, inclusive com a previsão de prorrogação de seus efeitos, ante a cláusula geral da boa-fé ${ }^{62}$.

Mesmo nos casos em que é permitida a resilição unilateral, o momento de eficácia da denúncia deve levar em conta as circunstâncias do caso (e não só os investimentos consideráveis) atendo-se ao momento de eficácia da denúncia à razoabilidade, segundo lição de AтIYAH: "O período de aviso da denúncia, se não expressamente acordado, variará conforme as circunstâncias do caso, mas deve sempre ser razoável e, em certos contratos, como contratos de trabalho ou locações, acaba sendo mais ou menos fixado em decorrência da forma de pagamento"63.

A tradição do common law sobre contratos de execução continuada baseava-se na noção de que a qualquer momento as partes poderiam facilmente se desvincular da relação, restando protegido um pequeno período de pré-aviso, o que também chamou a atenção de JACQUES AZÉMA, ao tratar, principalmente, do já mencionado declínio do direito de resilição unilateral do contrato de prazo indeterminado ${ }^{64}$.

Esta concepção, todavia, não é atualmente observada, especialmente na época da "maré baixa" do princípio da liberdade de contratar: "Estes direitos estatutários foram criados durante o período em que o princípio da liberdade contratual estava em maré baixa, e pode ser questionado por alguns se deve ser perpetuado em todas as circunstâncias. A necessidade destes nasce, em parte, porque o mercado, neste particular,

${ }^{62}$ Cf. L. DíEz-PicAzo e A. Gullón, Sistema de derecho civil, v. 2, $9^{\text {a }}$ Ed., Madrid, Tecnos, 2001, p. 247: "También cuando se trata de relaciones obligatorias duraderas que carecen de plazo contractual de duración y que se encuentran fundadas em la recíproca confianza que las partes merecen. (...) El esercicio de esa facultad se realiza mediante uma declaración de voluntad que há de ser recepticia. Debe ser hecha de buena fe (art. 7.1. Del Título Preliminar), lo que seguramente impondrá la existência de um plazo de preaviso (no disistir por sorpresa) y la necessidad de prolongar la realización por el tiempo necesario para que la outra parte tome suas medidas.”. V., também, a respeito, J. AzÉMA, La durée... cit., p. 174-181.

${ }^{63}$ An Introduction... cit., p. 395: "The length of the notice, if not expressly agreed upon, will vary according to the circumstances of the case, but it must always be 'reasonable' and in certain contracts, like contracts of employment and leases, it has come to be more or less standardized by reference to the method of payment".

${ }^{64}$ La durée... cit., p. 257-260. 
é frequentemente imperfeito, de modo que simplesmente não é possível para uma parte conseguir o que pretende em outro lugar se o contrato for levado a término" ${ }^{65}$.

Quem também se debruça sobre o tema é PAUlo HenRIQUES ${ }^{66}$, que afasta qualquer ofensa a direitos quando determinado um período compulsório de pré-aviso, a despeito de o Código Civil português não trazer disposição análoga ao art. 473, par. ún.

Destaque-se que este autor, discorrendo sobre os pressupostos da manutenção do contrato (pré-aviso), assere que o denunciante possui totais condições ("perfeitamente cognoscíveis") de avaliar as circunstâncias negociais adstritas ao denunciado e consequentemente os potenciais efeitos danosos de uma denúncia imatura. Neste sentido, pode-se argumentar que a manutenção do vínculo contratual prestigia a boa-fé, já que o denunciante conhece (ou ao menos deve conhecer) as peculiaridades envolvidas, conforme o standard de conduta de determinado negócio.

Destas premissas, é possível traçar um paralelo com a teoria da confiança (art. 113 do Código Civil), amplamente estudada entre nós. A noção de que a prorrogação do vínculo não fere direitos do denunciante exatamente porque ele sabe ou deve saber das consequências de seus atos está em evidente prestígio à confiança e, em última análise, à boa-fé, em detrimento da liberdade de contratar.

Saliente-se que o dispositivo em tela não é contemplado em inúmeras legislações estrangeiras, lembrando-se, contudo, o já mencionado art. 57 do Code Européen des Contrats.

65 "These statutory rights were created during the period when the principle of freedom of contract was at a low ebb, and it may be questioned by some whether they should be perpetuated in all circumstances. The need for them arises partly because the market in these matters is often very imperfect, so that it simply is not possible for one party to get what he needs elsewhere if his contract is terminated." (P. S. ATIYAH, An Introduction... cit., p. 396).

${ }^{66}$ Em pesquisa sobre a liberdade de desvinculação nos contratos por tempo indeterminado e os eventuais danos causados pela extinção do contrato, conclui o seguinte: "O período de pré-aviso deve possibilitar à parte destinatária da declaração da denúncia o empreendimento das diligências destinadas a preparar o período subseqüente à extinção da relação contratual. O tempo necessário ao desempenho dessas diligências depende da área de actividade, da maior ou menor flexibilidade da organização da parte denunciada, da influência da relação contratual no volume dos negócios - a qual assume maior importância quanto existe, de iure ou de facto, uma relação de exclusividade - e da própria conjuntura do mercado. Estas circunstâncias, indicadas a título meramente exemplificativo, são perfeitamente cognocíveis e avaliáveis pelo denunciante. Por isso não vislumbramos qualquer fonte de insegurança ou de imprevisibilidade nestes critérios. Mas importa acentuar que a quantificação do período de pré-aviso depende também da antiguidade da relação contratual" (A desvinculação unilateral ad nutum nos contratos civis de sociedade e de mandato, Coimbra, Coimbra Ed., 2001, p. 235 e ss.). 
Pois bem, conclui-se a final que o art. 473, par. ún., do Código Civil estipula norma em total consonância com a vedação geral ao abuso de direito, de modo análogo ao que a doutrina já havia há tempos ensaiado. Não bastam disposições específicas sobre determinados contratos de longa duração. É antes necessária a recepção de uma disciplina que, de modo geral, tutele todo e qualquer contrato de longa duração.

Feitos estes esclarecimentos, passa-se a discorrer sobre importantes fontes doutrinárias que serviram de fundamento dogmático para a inserção do art. 473, par. ún., no Código Civil vigente. 


\section{CAPÍTULO 3 - FUNDAMENTO DOGMÁTICO DO ART. 473, PAR. ÚN., DO CÓDIGO CIVIL}

Saliente-se que, na literatura brasileira, sobressaem alguns importantes trabalhos doutrinários que realçam as razões que justificaram, a inserção do art. 473, par. ún., no Diploma de 2002. Na verdade, dois estudos abordam especificamente esta referida regra legal. O primeiro de Miguel REALE ${ }^{67}$, autor da respectiva; e, o segundo, de TÉRCIO SAMPAIO FERRAZ JR. ${ }^{68}$.

Mais do que a chamada liberdade do trabalho em geral, prevista no art. $5^{\circ}$, XIII, a Constituição Federal também estatui, em seu art. 170, a liberdade de empresa. Esta diretriz abrange algumas faculdades, quais sejam: “a) a de livre escolha da atividade econômica a ser exercida, podendo esta ter o mais variado espectro; b) a de livre estruturação ou sistematização mais compatível com a natureza da atividade preferida (...); c) a da livre escolha de terceiros como seus colaboradores, no amplo das relações disciplinadas pelo direito Civil, o direito Comercial, o direito Econômico, etc. ${ }^{~} 69$.

A própria liberdade de contratar, prevista neste art. 170, também decorre da livre iniciativa frente à limitação ao abuso do poder econômico, a teor do art. $173, \S 4^{\circ}$, da Constituição Federal $^{70}$.

FERRAZ JR. observa também que dos nove princípios da ordem econômica, cujo elenco é previsto no citado art. 170 da Constituição Federal, só o segundo ("propriedade privada") e o quarto ("livre concorrência") apontam para uma plena e

${ }^{67}$ Resilição... cit., p. 33-46.

${ }^{68}$ Resilição unilateral de relações comerciais de prazo indeterminado e lei de defesa da concorrência, in Caderno de Direito Tributário e finanças públicas, n. 4, São Paulo, Ed. RT, jul-set/1993, p. 270-279.

${ }^{69}$ M. ReALE, Resilição... cit., p. 35.

${ }^{70}$ T. S. FERRAZ JR., Resilição... cit., p. 271. 
radical liberdade da vontade. Todos os demais buscam dar a "justa medida” ao exercício da atividade econômica ${ }^{71}$.

Sobre esta "justa medida”, Miguel ReAle pontua que, ao mesmo tempo, o Estatuto Político declara a livre iniciativa e a livre concorrência como princípios da ordem econômica, bem como confere ao Estado papel de agente econômico e, em caso de segurança nacional ou se necessário certo estímulo à economia, "poderes para atuar diretamente no mundo empresarial ${ }^{, 72}$.

Ainda neste sentido, mormente no tocante ao setor privado, não se pode olvidar a norma prevista no art. 174 da Constituição Federal, pelo qual são claramente consignadas as funções do Estado de "fiscalização, incentivo e planejamento, sendo este determinante para o setor público e indicativo para o setor privado”.

Assim sendo, Miguel ReALE arremata: “À vista desse quadro, reduz-se a puro sofisma a afirmação de que o Brasil prevalece, hoje em dia, como regra geral, a intervenção estatal na ordem econômica..."73. Via de regra, portanto, impera a não intervenção estatal na vida econômica. Há, contudo, abertura para exceções, desde que mediante lei, em consonância com o ordenamento constitucional ${ }^{74}$.

De tudo, tem-se a premissa pela qual, no plano das atividades econômicas, ou no domínio específico dos contratos - "as quais, tudo somado, são corolários legítimos da livre iniciativa" - em princípio, não há intervenção estatal. Como acima mencionado, existirão, entretanto, casos de intervenção por imperativos legais de ordem pública exatamente para prestigiar, por exemplo, a proteção do meio ambiente, a defesa do consumidor ou a vedação ao abuso de pode econômico.

\footnotetext{
${ }^{71}$ T. S. FERRAZ JR., Resilição... cit., p. 274 e, ainda: "Nesse contexto é que se insere a legislação de Direito Econômico, cujo objetivo é cuidar para que o desenvolvimento econômico ou técnico do sistema mercadológico não seja comprometido por comportamentos dos agentes que possam levar a distorções, como o impedimento do afluxo de recursos a certos setores ou o bloqueio da possibilidade de expansão de concorrentes ou a mera afirmação da prepotência econômica que, sem maiores justificações, seja manifestação de um poderio arbitrário".

${ }^{72}$ M. REALE, Resilição... cit., p. 35.

${ }^{73}$ M. REALE, Resilição... cit., p. 36.

${ }^{74}$ M. REALE, Resilição... cit., p. 36.
} 
Precisamente com este intuito: vedar o abuso de poder econômico, é possível compreender a norma estipulada no art. 473, par. ún., do Código Civil.

Nem se diga, por isto, que o dispositivo estaria deslocado no Código Civil, devendo permanecer adstrito ao campo de defesa da livre concorrência. FERRAZ JR. bem esclarece que, ao contrário de uma visão antiga, a Constituição Federal vigente está antes preocupada com a repercussão de todos os atos no mercado, do que com um ato individual, consciente e intencional, a ferir a ordem econômica e a livre concorrência, como se o agente deliberadamente agisse com este escopo. "Este é o novo sentido da linguagem de finalidade em seu contexto contemporâneo ",75.

Os conflitos ocorridos podem e devem ser tratados por distintas legislações, não havendo razão para a inserção neste ou naquele ramo do direito. Uma relação jurídica pode ser tutelada por normas e princípios de diferentes áreas e, assim, um ato jurídico pode ser caracterizado como concorrência desleal, ilícito civil ou infração administrativa ${ }^{76}$.

Desse modo, se é certo que o escopo da norma é a vedação ao abuso de poder econômico, revela-se necessário interpretar o significado de tal fundamento. Neste sentido, Miguel Reale, buscando afastar qualquer indesejada vagueza do conceito, mormente "para que o legislador ordinário e os intérpretes da lei (juizes e administradores) não se perdessem em generalidades teleológicas" "77, lembra que todas as Constituições brasileiras desde a de 1946, no tocante à ordem econômica, explicitam os três fins que podem e devem ser considerados abusivos, quais sejam: a) domínio de mercado; b) eliminação da concorrência; c) aumento arbitrário dos lucros (atualmente, art. 173, § $4^{\circ}$ ).

Por fim, já é possível concluir que, mais do que buscar a vedação ao abuso do poder econômico, a norma estatuída no art. 473, par. ún., do Código Civil, visa coibir o aumento arbitrário dos lucros, segundo precisa observação do próprio MiGUEL REALE:

"Saliento, desde logo, que esse dispositivo, bem como o da "resolução por onerosidade excessiva" (Arts. 478 e segs. do Projeto), conforme resulta da "comunicação", supramencionada à $V$ Conferência Nacional da Ordem dos Advogados, foram por mim configurados como

\footnotetext{
${ }^{75}$ T. S. FERRAZ JR., Resilição... cit., p. 274-275.

${ }^{76}$ T. S. FERRAZ JR., Resilição... cit., p. 274.

${ }^{77}$ Resilição... cit., p. 39.
} 
hipóteses conexas de abuso de poder econômico, por tratar-se de atos que implicam, por parte de seus autores, o propósito de auferir vantagens ilícitas em prejuízo de outrem, o que equiparei à proibição constitucional de valer-se alguém da livre iniciativa a fim de lograr "aumento arbitrário de lucros.

Equiparei, em suma, no referido estudo, por analogia, 'vantagens ilícitas' com 'lucros ilícitos', mas não sem advertir que abuso de poder econômico e abuso de direito são 'conceitos jurídicos distintos', muito embora no plano efetivo da praxis muitas vezes se combinem para atentar contra situações subjetivas merecedoras de amparo."$^{78}$

Pois bem, se a prorrogação contratual compulsória é ferramenta à disposição do intérprete para coibir o abuso de poder econômico, obstando o aumento arbitrário dos lucros, por que é necessário justificá-la diretamente da Constituição Federal, se a norma ordinária veda, por óbvio, o abuso de direito e o enriquecimento sem causa?

Miguel ReAle, no estudo apontado, escreve que, embora "abuso de direito" e "abuso de poder econômico" sejam conceitos diferentes, na hipótese de uma empresa impingir prejuízo à outra ("com o deliberado objetivo de alcançar vantagens arbitrárias ",79), haveria uma situação de coexistência de abuso de direito e abuso de poder econômico.

Em sentido distinto, FERRAZ JR, defende a existência de dois tipos de resilição abusiva do contrato: ruptura por abuso de direito e aquela por abuso do poder econômico. $\mathrm{Na}$ primeira modalidade, a autonomia da vontade deve ser preservada (permitindo-se a extinção do vínculo), reputando-se hipótese de ilícito civil passível de reparação. Quanto ao abuso do poder econômico, deve ser prorrogada a relação para respeitar o interesse maior do mercado.

Permite-se, assim, concluir que a indenização por perdas e dano pode até satisfazer o contratante lesado (nem sempre será o caso) e a manutenção compulsória do

\footnotetext{
${ }^{78}$ M. REALE, Resilição... cit., p. 45.

${ }^{79}$ M. REALE, Resilição... cit., p. 45.
} 
vínculo, por sua vez, atenderá a um interesse maior de mercado ${ }^{80}$, desde que esta também seja a vontade do contratante lesado. Não seria, assim, justificável tutelar o interesse maior de mercado em detrimento do interesse de um ou outro contratante.

Com efeito, Ferraz JR. aponta a norma do art. $3^{\circ}$, IX, da Lei n. 8.158/1991 (atual art. 36, $\S 3^{\circ}$, XII da Lei n. $11.529 / 2011^{81}$ ), semelhante àquela do art. 473, par. ún., do Código Civil, como uma opção ao intérprete de intervir nas relações mercantis privadas em nome de um interesse maior no mercado concorrencial. Em suma, o abuso de poder econômico, mais abrangente do que abuso de direito, estaria configurado quando o custo de investimento de certa relação contratual influencia não só o interesse das partes, mas também o interesse da sociedade como um todo ${ }^{82}$.

Tome-se, por exemplo, um contrato de fornecimento de tomates para o processamento de molho concentrado, com alta demanda, alto nível de exigência quanto à qualidade e padrão da mercadoria vendida. A compradora procede a uma denúncia unilateral abrupta e inesperada de forma a ser reputada em flagrante exercício abusivo do direito de resilir e, assim sendo, a conduta é passível de sanção legal.

Pela perspectiva de FERRAZ JR., só seria justificável cogitar a prorrogação compulsória caso o comportamento da denunciante implicasse consequências que afetassem profundamente o mercado no qual está inserida tal relação de fornecimento.

Haveria, portanto, abuso de poder econômico se, em decorrência da inesperada resilição unilateral, a fornecedora de tomates sofresse prejuízos de tamanha monta de forma a alterar vertiginosamente sua posição no mercado, implicando consequências prejudiciais, por exemplo, às fazendas que cultivavam o tomate em decorrência da diminuição na venda, e, em efeito cadeia, a vendedora de defensivos agrícolas também sofresse com a inesperada quebra, sem falar em impactos diretos a trabalhadores na região. Enfim, é precisamente pelo poder econômico de certo agente que o exercício abusivo de

\footnotetext{
${ }^{80}$ T. S. FERRAZ JR., Resilição... cit., p. 277.

81 "§ $3^{\text {o }}$ As seguintes condutas, além de outras, na medida em que configurem hipótese prevista no caput deste artigo e seus incisos, caracterizam infração da ordem econômica:

XII - dificultar ou romper a continuidade ou desenvolvimento de relações comerciais de prazo indeterminado em razão de recusa da outra parte em submeter-se a cláusulas e condições comerciais injustificáveis ou anticoncorrenciais".

${ }^{82}$ T. S. FERRAZ JR., Resilição... cit., p. 278.
} 
qualquer direito e, neste caso, do direito de resilir pode e deve ser evitado com a prorrogação do contrato de forma a atenuar as consequências gravosas causadas não só à parte contratante, mas também à sociedade como um todo.

Por outro lado, se, por qualquer motivo, a denúncia unilateral, ainda que abusiva, implique consequências unicamente gravosas ao outro contratante, não há que se falar em abuso de poder econômico, mas tão somente em abuso de direito. Neste caso, a sanção legal deveria ser a reparação civil, pois, em última análise, o ordenamento só precisa tutelar o interesse do outro contratante, o que pode muito bem ser feito mediante indenização pecuniária.

Já, segundo as lições acima analisadas de Miguel ReALE, no que toca à finalidade do art. 473, par. ún., do Código Civil, não existem diferenças, se não conceituais, quanto à vedação ao abuso de direito ou do poder econômico, ou seja, quando certo contratante abusa de seu poder econômico e intenta deixar certa relação contratual de longa duração, só o faz abusando de seu direito de resilição.

A noção de poder econômico no sentir de MiguEL REALE não depende da evidência de consequências diretas a outros agentes do mercado, eis que o acometimento de prejuízos ao outro contratante é suficiente para caracterizar não só o abuso de direito, mas o abuso de poder econômico que justifica a imperiosidade de que a denúncia unilateral seja compatível com a natureza e vulto dos investimentos realizados pela contraparte, ainda que por imposição judicial.

Já quanto às ponderações de FERRAZ JR., a comparação entre o abuso de poder econômico e o abuso de direito é mais assertiva na medida em que a prorrogação compulsória só merece ser alvitrada quando o contratante abusa de seu poder econômico em detrimento do interesse maior da sociedade. Prorroga-se o contrato, não exatamente pelo direito da contraparte, mas pelo interesse da sociedade.

Para os fins deste estudo, adota-se a posição de Miguel REALE, principalmente porque, quanto à relação interna entre contratantes, seria tarefa deveras complicada traçar distinções entre os efeitos do abuso de direito ou de poder econômico. 
Conclui-se, pois, não haver consequências distintas a depender da natureza do abuso que lastreia a denúncia, pois o abuso do direito de resilir é, por excelência, caso de abuso de poder econômico.

Em sentido similar, oportuno é aduzir à conclusão de ANNE-SoPHIE LABORDERIE, ao afirmar que os limites à resilição unilateral decorrem da ordem pública e perseguem dupla finalidade: tutela o interesse do particular e outrossim o interesse geral em consideração ao equilíbrio econômico ínsito à sociedade ${ }^{83}$.

É antes a natureza do próprio contrato e o momento da intentada resilição que fornecem indícios para auxiliar o intérprete a impor a sanção mais adequada, a teor, inclusive, do que, em sequencia, será demonstrado neste trabalho.

${ }^{83}$ La pérennité... cit., p. $481, \S 865$. 


\section{CONSIDERAÇÕES CONCLUSIVAS DA PARTE I: A PRORROGAÇÃO COMO SANÇÃO LEGAL}

Pelas premissas teóricas até aqui traçadas, procurou-se demonstrar as razões e fundamentos pelos quais a prorrogação dos contratos de longa duração deve ser considerada uma sanção passível, ope iudex, de ser imposta, não devendo a resilição unilateral ilícita ser unicamente sancionada pela tutela indenizatória derivada da responsabilidade civil.

Das premissas expostas sobre a liberdade contratual, restaram explicitados os motivos pelos quais a norma do art. 473, par. ún., do Código Civil, não pode ser unicamente interpretada como regra que impõe aos contratantes o dever de postergar os efeitos da denúncia unilateral compatível com os investimentos da contraparte, sob pena de obrigação de indenizar.

Em seguida, demonstrou-se que há tempos a experiência jurídica brasileira como algumas estrangeiras vislumbram, sem dificuldades, inafastáveis limites ao direito de resilição unilateral. No Brasil, o conceito de abuso de direito a gerar ato ilícito, nos termos do art. 187 do Código Civil, é o que se adequa à eventual denúncia antijurídica. A resilição unilateral, quando abusiva, assim o será por exercício irregular de um direito.

Nas hipóteses em que um contratante proceda à denúncia do contrato em violação objetiva ao disposto no contrato, não há se falar em prorrogação do contrato, mas em execução específica do avençado, a teor do art. 475 do Código Civil, e não pela norma prevista no art. 473, par. ún.

Das lições de Miguel Reale, ademais, sobre a mens legis da norma posta, restou claro que a finalidade do dispositivo, per se, é a de coibir o abuso de poder econômico consubstanciado na conduta abusiva no exercício da denúncia unilateral ${ }^{84}$.

Cumpre esclarecer que, em seguida, na Parte II do presente estudo tratar-se-á das relações contratuais duradouras, para explanar vicissitudes peculiares dos contratos de longa duração, que permitem extrair uma gama de variantes capazes de incitar nova abordagem sobre a noção de abusividade no exercício da resilição unilateral.

\footnotetext{
${ }^{84}$ V., no mesmo sentido C. M. S. PEREIRA, Instituições de Direito Civil, v. 3, $12^{\mathrm{a}}$ ed., Rio de Janeiro, Forense, 2007, p. 152.
} 
Como se verá, tais proposições não inovam o paradigma dogmático dominante, mas revelam maior pragmatismo na medida em que fornecem reflexões mais concretas. 


\section{PARTE II - CONTRATOS DE LONGA DURAÇÃO: CARACTERÍSTICAS ESPECÍFICAS}

\section{CAPÍtUlO 1 - CONTRATOS DE LONGA DURAÇÃo E SUA EXTINÇÃO}

A resilição, ato de vontade de terminar um contrato $^{85}$, é gênero que admite várias espécies $^{86}$. Dentre as formas principais admitidas pela dogmática jurídica, estão a revogação, renúncia e a denúncia.

A revogação é a "retirada da voz por parte do autor do negócio jurídico"87. Revoga-se a manifestação de vontade. A expressão é carregada de certa conotação. Não se fala em revogação abusiva ou revogação ilícita. A revogação é usualmente forjada somente nas situações em que há revogabilidade ${ }^{88}$.

A despeito de ser efetivada frequentemente nos negócios gratuitos, a característica principal dos negócios que admitem revogação, é a confiança, a exemplo do mandato ${ }^{89}$.

A eficácia será ex tunc ou ex nunc, dependendo do contrato, uma vez que: "quem revoga poderes outorgados que já foram em parte exercidos somente revoga ex nunc ${ }^{, 90}$.

Quanto à renúncia, ela opera-se mediante vontade única do titular de certo direito. É “ato unilateral de disposição do titular de um direito, desfazendo, ex nunc, a

\footnotetext{
${ }^{85}$ Na definição de F. C. PONTES DE MIRANDA: "Resolver é solver, como dissolver; resilir é sair. Solve-se, resolve-se, sim, na resilição, mas saindo-se, saltando-se: o que restaria para a eficácia do contrato deixa de irradiar-se, porque o figurante saltou fora, e resolveu-se, ex nunc, o contrato (= descontituiu-se o seu futuro eficacial)." (Tratado de Direito Privado, t. 25, $2^{\text {a }}$ ed., Rio de Janeiro, Borsoi, 1959, p. 305-306).

${ }^{86}$ Cf. R. R. Aguiar JR., Comentários ao novo Código Civil, v. 6, t. 2, coord. Sálvio de Figueiredo Teixeira, Rio de Janeiro, Forense, 2011, p. 264 e, no mesmo sentido, A. J. GoMIDE, Direito de arrependimento nos contratos (dissertação-UL), Lisboa, 2009, p. 31.

${ }^{87}$ R. R. AgUiar JR., Comentários... cit., p. 264.

${ }^{88}$ Cf. R. R. Aguiar JR., Comentários... cit., p. 265; e F. C. PONTES DE MiRAndA, Tratado... t. 25 cit., p. 270: "Não há indenizabilidade, porque quem revoga só o faz porque pode revogar. A revogação do irrevogável é sem qualquer eficácia”.

${ }^{89}$ Cf. R. R. Aguiar JR., Comentários... cit., p. 265.

${ }^{90}$ F. C. PONTES DE MiRAndA, Tratado... t. 25 cit., p. 279.
} 
relação negocial"91. O renunciante dispõe sobre o direito de que é titular" ${ }^{92}$ O "sócio, que se retira, renuncia"93. O mandatário é outro também que pode renunciar a seus poderes, ainda que responda por perdas e danos (art. 688 do Código Civil). Na qualidade de ato unilateral de disposição, os efeitos da renúncia só atingem o futuro (ex nunc).

Observe-se que a renúncia não ocorre estritamente no âmbito contratual, mas também em casos de renúncia à herança (art. 1804 e 1812), à servidão (art. 1388, I) ou à prescrição (art. 191).

Já a denúncia é definida por PONTES DE MIRANDA, em trecho que vale ser transcrito:

"Nas relações jurídicas duradouras, é preciso que possa ter ponto final o que se concebeu em reticência. Porque relação jurídica duradoura a que não se pudesse pôr termo seria contrária às necessidades da livre atividade dos homens. Não bastaria subordiná-la a eventual resolução por inadimplemento ou ao distrato. Daí a figura da denúncia, com que se des-nuncia, pois resulta de se haver atribuído a algum dos figurantes o direito formativo extintivo, que é o de denunciar. De ordinário, os figurantes previam e prevêem êsse direito formativo extintivo, igual ou diferentemente. Todavia, a lei atendeu a que há muitas espécies em que se impunha a regra jurídica - cogente, dispositiva ou interpretativa sôbre o direito formativo extintivo e estatuiu sôbre os pressupostos dêsse direito." 94

Desse modo, a denúncia é a resilição unilateral típica das relações contratuais duradouras. Como salientado por AgUiAR JR., o art. 473 caput do Código Civil quando aponta a denúncia como ferramenta de efetivação da resilição, na verdade, está direcionado para qualquer tipo de resilição, seja operada por revogação, renúncia ou denúncia ${ }^{95}$.

\footnotetext{
${ }^{91}$ R. R. Aguiar JR., Comentários... cit., p. 282.

92 Cf. F. C. PONTES DE MiRAndA, Tratado... t. 25, cit., p. 302: “Mas, enquanto a denúncia só afasta que efeitos futuros se produzam, sem dispor, a renúncia é ato dispositivo. Quem denuncia não dispõe; dispõe quem renuncia”.

${ }^{93}$ F. C. PONTES DE MIRANDA, Tratado... t. 25, cit., p. 296.

${ }^{94}$ Tratado... t. 25, cit., p. 295-296.

${ }^{95}$ Cf. R. R. Aguiar JR., Comentários... cit., p. 285.
} 
Apesar desse pormenor, é possível reconhecer que o art. 473, par. ún., do Código Civil, impõe regra exclusivamente direcionada às hipóteses de denúncia. Por este motivo, sem embargo do mencionado equívoco no legislador no caput, há precisão técnica na redação do parágrafo único.

Seguidamente, pode-se afirmar sem hesitação que a prorrogação compulsória só possui espaço em relações duradouras. Ainda, a lógica de tutela de investimentos realizados pelas partes apenas se coaduna com os negócios jurídicos em que o tempo é elemento essencial e não acidental. Assim, nos contratos de execução diferida, ainda que exista longo tempo entre a assunção da obrigação e o adimplemento, a norma citada não incide, como se verá mais adiante.

Lida-se, portanto, exclusivamente com os ditos contratos de trato sucessivo ou de execução continuada.

Novamente, quanto às distinções conceituais, AGUIAR JR. ${ }^{96}$, a exemplo de outros autores e da posição adotada nesse estudo, tem a resilição unilateral como gênero que engloba várias espécies. Em sentido oposto, PONTES DE MIRANDA ${ }^{97}$ admite nuances específicas para cada tipo de "extinção das dívidas por atitudes desconstitutivas dos figurantes".

A presente pesquisa não exige uma investigação aprofundada sobre os conceitos ponteanos acerca da temática focada, valendo a ressalva de que entre o conceito de resilição e denúncia, ambos centrais neste estudo - e tratados como sinônimos, já que representam gênero e espécie -, a distinção de PONTES DE MIRANDA é deveras sutil.

Ambas produzem efeitos ex nunc, mas, pela denúncia, apenas determina-se a não continuidade dos efeitos do negócio jurídico. Já a resilição desfaz a eficácia do negócio jurídico: “Tem-se o negócio jurídico como concluído mas extinto no momento em que se resile. Não se confunde com a denúncia, porque essa não desconstitui: determina, apenas, que não continue ",98.

\footnotetext{
${ }^{96}$ Comentários... cit., p. 264.

${ }^{97}$ Tratado... t. 25, cit., principalmente, p. 269-349.

${ }^{98}$ F. C. PONTES DE MIRANDA, Tratado... t. 25, cit., p. 308.
} 
Adotando-se, sem ressalva, a classificação ponteana, ainda assim, o art. 473, par. ún., do Código Civil, encontra-se com seu rigor técnico inequivocamente mantido, pois só a denúncia (que determina que o negócio não continue) pode ser prorrogada para que sua eficácia seja iniciada em momento posterior. A mesma lógica não se alinharia ao conceito de resilição, visto que este corresponderia ao ato de desconstituir o negócio jurídico de eficácia.

Ressalte-se, por oportuno, que a natureza jurídica da denúncia é a de negócio jurídico, uma vez que seus efeitos podem ser convencionados pelas partes, inclusive o aviso prévio da denúncia não deixa de ser estipulação sobre sua eficácia. No mais, é negócio jurídico unilateral, pois só depende da manifestação de vontade do denunciante.

Não se pode confundir, ademais, a denúncia com a notificação, esta ato jurídico stricto sensu ${ }^{99}$. Certamente, a denúncia só se aperfeiçoa com a ciência da contraparte, mas não por sua aceitação.

Definida a natureza da ruptura contratual (denúncia) sobre a qual incide a norma do art. 473, par. ún., do Código Civil, é certo que a doutrina discorre amplamente sobre quais relações contratuais podem ser descontinuadas. Seguramente, aquelas por prazo indeterminado; nas contratações por prazo determinado desde que previsto em lei, $v$. g., a locação; ou quando o direito de resilição unilateral houver sido convencionado pelas partes.

Sobre as hipóteses em que a lei expressamente permite a resilição unilateral, pode-se citar o art. 688 do Código Civil, que estipula a faculdade de renúncia unilateral do mandato, ou o art. 720 e seu parágrafo único, sobre norma virtualmente idêntica àquela analisada, mas na esfera dos contratos de agência e distribuição.

Na legislação extravagante, a Lei de locação predial urbana (n. 8.245/1991) é a que mais prevê hipóteses de denúncia unilateral, como se infere dos arts. $6^{\circ}$ (locação por

\footnotetext{
${ }^{99}$ V., a respeito, F. C. PONTES DE MiRAnda, Tratado... t. 25, cit., p. 304. E, mais especificamente, v. F. C. Pontes De Miranda, Tratado de Direito Privado, t. 1, 2a ed., Rio de Janeiro, Borsoi, 1954, p. 84: “Alguns atos humanos são exteriorizações (inclusive comunicações) de fatos psíquicos sem o intuito da criação de negócio jurídico; e.g. exteriorizações de conhecimento, de sentimento, de vontade. É ex lege que lhes decorrem a juridicidade e a eficácia: a lei os faz jurídicos e lhes atribui efeitos, quer os tenha querido ou não, as pessoas que os praticaram. Esse fato de poderem ter sido queridos os efeitos não os faz declarações de vontade, nem manifestações de vontade negociais; mas é bastante para que se submetam a certas regras que são, também, para as declarações de vontade e as manifestações de vontade criadoras de negócios jurídicos".
} 
prazo indeterminado), $7^{\circ}$ (extinção de usufruto ou de fideicomisso), $8^{\circ}$ (alienação do imóvel), 46, § $2^{\circ}$ (locação residencial), 50, par. ún. (locação para temporada), e 57 (locação não residencial).

Outro exemplo é encontrado na chamada Lei Ferrari (n. 6.729/1979) que trata da concessão comercial entre produtores e distribuidores de veículos automotores de via terrestre. $\mathrm{O}$ art. 21 deste diploma regra não só o direito à renúncia unilateral, mas também a contratação por prazo mínimo de cinco anos.

Sem prejuízo de análise detalhada destes casos, destaque-se que, em sua monografia específica, JACQUES AZÉMA ${ }^{100}$ demonstrou significativa inquietude ao constatar que o ordenamento atual insinua uma separação completa entre relações duradouras por prazo determinado ou indeterminado. Com efeito, sua obra trouxe pontos de encontro entre os contratos por prazo indeterminado e aqueles com termo definido.

A pedra de toque para JACQUES AZÉMA, ao propor que as relações por prazo determinado ou indeterminado podem ser estudadas de forma idêntica, está consubstanciada na intervenção estatal no domínio dos contratos e na evolução da teoria do abuso de direito, ou seja, a ruptura contratual abusiva é repelida e impedida pelo sistema ${ }^{101}$.

Não mais se busca aspectos subjetivos que levam o contratante à resilição unilateral. Procura-se evitar o abuso do direito de resilir em momento inoportuno a fim de evitar a frustração do interesse contratual da outra parte.

\footnotetext{
${ }^{100}$ La durée... cit., p. 189-276. V., também, , P. D. R. ARAUjo, Prorrogação... cit., p. 133-141.

${ }^{101}$ V. P. D. R. ARAUJo, Prorrogação compulsória de contratos a prazo - pressupostos para sua ocorrência (tese-USP), São Paulo, 2011, p. 133: "Essa aproximação entre os dois tipos contratuais é o último tema do qual o autor se ocupa em sua obra. Ele afirma serem dois os pontos merecedores de análise nesse aspecto. $O$ primeiro é a ineficácia relativa dos termos contratuais, haja vista o esforço doutrinário e jurisprudencial para relativizar a regra de que não é possível sair do contrato antes do término do prazo. O segundo se refere à doutrina do abuso de direito de resilir os contratos por tempo indeterminado, tema de importância capital na opinião do autor. A escolha de determinado prazo contratual pode ser desastrosa. De um lado, o prazo pode ser mais longo que o necessário e a liberdade contratual das partes ficará severamente comprometida. De outro, o prazo pode ser muito curto, o que compromete a própria utilidade daquele contrato. É por conta disso que a legislação e a jurisprudência francesas têm criado situações que permitem a ruptura do contrato antes do prazo e, em outros casos, obrigam as partes a permanecer unidas para além do prazo contratual”.
} 
Desse modo, dois seriam os casos em que contratos por prazo determinado possuem regime similar. Quando o contrato prever a possibilidade de saída antecipada ou quando o contrato for tacitamente prolongado $^{102}$.

Quanto ao caso de existir cláusula permitindo a resilição antecipada em contrato com termo, JACQUES AZÉMA explica que a jurisprudência francesa estipula uma transformação do contrato por tempo determinando quando exercida a denúncia unilateral para resilir ${ }^{103}$.

A solução encontrada nos pretórios franceses está deveras arraigada à tradição fixa de que se há possibilidade de resilição unilateral, logo o contrato é por tempo indeterminado ${ }^{104}$.

Tal tradição remonta ao Code Civil em seu art. 1.780, o qual, dentre outras disposições, estipulava: “O aluguel de serviços, sem determinação da duração, pode sempre cessar pela vontade de uma das partes contratantes $" 105$.

JACQUES AZÉMA, contudo, discordava do que chamou de "metamorfose" e preferia reputar o contrato com duração definida de natureza híbrida entre ambos os regimes.

Mais recentemente, PAULO ARAÚJO discordou desta conclusão ao propor que um contrato com prazo determinado e possibilidade de resilição unilateral estabeleceria um vínculo por prazo indeterminado, mas com tempo máximo de duração: “O contrato há de ser qualificado como contrato por tempo indeterminado (pois não há prazo mínimo garantido), com estipulação de tempo máximo de duração" ${ }^{106}$.

102 J. AZÉMA, La durée... cit., p. 224-225.

${ }^{103}$ La durée... cit., p. 192: "la jurisprucende à souvent décidé que la clause transformait le contrat en um contrat à durée indetermininée". Em tradução livre: "A jurisprudência frequentemente decidiu que a cláusula transformava o contrato em um contrato por prazo indeterminado".

${ }^{104}$ V., também a respeito, A. L. LABORDERIE, La pérennité...cit., p. 476, § 858.

${ }^{105}$ Em tradução livre de: "Le louage de service, fait sans détermination de durée, peut toujours cesser par la volonté d'une des parties contractantes.".

${ }^{106}$ Prorrogação... cit., p. 134, nt. 218. 
Permite-se, neste momento, discordar desta posição em que o direito de resilição é tratado como um elemento essencial do negócio a ponto de sua previsão implicar a mudança da natureza temporal do vínculo contratual.

Consoante o art. 473 do Código Civil, a resilição unilateral é permitida "nos casos em que a lei expressa ou implicitamente o permita”. Destarte, nesta pesquisa, ao invés de definir como se caracterizam os contratos que tenham previsto a resilição unilateral, admite-se a possibilidade da cláusula de resilição unilateral tanto em relações com prazo determinado ou não.

É por esta razão, inclusive, que se admite a possibilidade de estipular resilição unilateral em contratos por adesão. O direito de resilir não deve ser reputado "resultante da natureza do negócio" (a teor do art. 424 do Código Civil), pois não é essencial a nenhum tipo de contrato. Pelo contrário, pode ser admitido em qualquer relação de longa duração, como se verá detalhadamente na terceira parte desta dissertação.

Já sob outro aspecto, JACQUES AZÉMA, além de afirmar que em inúmeras passagens que o direito de resilir é um elemento essencial do negócio por tempo indeterminado, aduz ainda que eventual cláusula de resilição unilateral em contratos com termo, só será eficaz se for bilateral.

Também não se concorda com tal conclusão. É preciso antes considerar a distribuição de riscos entre as partes, culminando com o fato de que, em dado momento, a resilição de uma parte pode irromper flagrantemente abusiva, mas a da outra parte pode estar revestida de completa licitude.

Dificilmente, é verdade, uma relação contratual poderá estipular a priori um direito absoluto e perene de resilição unilateral somente para uma das partes, mas dada a formação constante e dinâmica do vínculo contratual, haverá momentos em que o direito só poderá ser exercido de forma regular por uma parte.

Assim sendo, a conclusão delineia-se no sentido de que a resilição unilateral é gênero de extinção do vínculo contratual em decorrência da vontade de um contratante. Algumas espécies são admitidas, mas nas relações de longa duração, a resilição é exercida por meio de denúncia comunicada à contraparte. 
Verificou-se outrossim que, longe de uma tradição pela qual a resilição unilateral decorria do direito atinente somente às relações duradouras sem prazo, modernamente, a resilição unilateral é também costumeiramente convencionada em contratos por prazo determinado.

Normalmente, em contratos por prazo determinado, a resilição unilateral implica a cominação de multa compensatória. A simples existência de uma contraprestação em caso de denúncia contratual não afasta, entretanto, a possibilidade de o contrato dever ser compulsoriamente prorrogado, como se verá na parte final deste trabalho.

Sendo assim, ainda é preciso cuidar da influência do tempo no programa contratual para, em seguida, ater-se às novas teorias contratuais. 


\section{CAPÍTULO 2 - REFLEXÕES SOBRE A INFLUÊNCIA DO TEMPO NO REGIME DOS CONTRATOS}

Para os fins deste estudo, é fundamental compreender como o aspecto temporal dos negócios jurídicos exerce influência muito maior do que pode parecer, sobretudo nos contratos duradouros.

Como se verá, mais do que uma marcação linear, modernamente, o tempo contratual é interpretado como importante fator para analisar as condutas de cada contratante.

Por meio da seguinte análise da influência temporal nos contratos de longa duração, pretende-se elucidar as bases conceituais para justificar porque algumas condutas, aparentemente em perfeita consonância com o espírito da lei e do contrato, podem ter conotação abusiva.

Oportuna é a lembrança de que a contratação por longos períodos passou a ocorrer em muito maior escala ante a crescente complexidade contratual derivada, em última análise, da Revolução Industrial. Dentre tantas outras figuras jurídicas, a percepção sobre a influência do tempo nos contratos também foi alvo de significativa transformação.

Sobre uma concepção ainda voluntarista do contrato, PAULO ARAÚJO explica que a relação entre o tempo e o contrato guardava pertinência somente com os momentos de formação e execução do contrato ${ }^{107}$. A grande influência do tempo dizia respeito exclusivamente à individualização do momento de ocorrência do ato. Assim, era revelada a legislação aplicável, o dies a quo do termo ou do prazo prescricional, etc.

Neste contexto, alterações circunstanciais supervenientes pouco importavam. Prevaleciam as decisões tomadas no momento da formação do contrato. Ato contínuo, o momento de adimplemento do contrato era decorrência lógica da obrigação antes assumida, ou, nas palavras de PAULO ARAúJO: “Como a execução do contrato nada mais é do que o prolongamento no tempo da previsão estática concebida na formação contratual,

${ }^{107}$ Prorrogação... cit., p. 59. 
nada do que foi pactuado anteriormente poderá ser alterado posteriormente. Daí porque ser o contrato originalmente imutável e intangível, pois o tempo não volta". ${ }^{108}$

A ideia central, desenvolvida a partir do pensamento aristotélico, concentravase na sensação de que, em um determinado momento, certo cidadão (livre) havia consentido com uma restrição de sua liberdade (obrigação). O tempo, com efeito, passava a ser indicativo do momento em que liberalidade deveria ser, de fato, cumprida ${ }^{109}$.

Com a ascensão do liberalismo, nada mais natural do que a ratificação e revalorização de tal compreensão. Ora, como visto, se cada cidadão era livre para dispor de seus bens como desejasse, naturalmente as obrigações livremente assumidas deveriam ser honradas, sem embargo do intervalo de tempo entre a formação e execução do contrato.

Diante deste paradigma, o que distinguia o vínculo obrigacional dos demais era a lei. Se os elementos formadores do vínculo estivessem previstos em lei, ou dela pudessem ser deduzidos, a relação seria jurídica obrigacional e, como visto, imutável e inflexível $^{110}$. A força obrigatória dos contratos, consubstanciada no princípio pacta sunt servanda, emanava como axioma imutável.

A exemplo do que foi detalhado na primeira parte desta dissertação, após o sucesso do liberalismo, em um momento de crescente complexidade nas relações civis, o contrato rapidamente passa a ser a "principal forma de organização"111 da sociedade. A concepção voluntarista já não mais se sustentava. A intangibilidade e a imutalidade, outrora importantes dentro da lógica clássica, já não se coadunavam com os novos desafios da sociedade moderna ${ }^{112}$.

Não demorou muito, com o início de um crescente movimento de intervenção estatal no domínio dos contratos, a influência do aspecto temporal tornou-se algo muito mais expressiva e influente.

\footnotetext{
${ }^{108}$ Prorrogação... cit., p. 61.

${ }^{109}$ P. D. R. de ARAújo, Prorrogação... cit., p. 62.

${ }^{110}$ Cf. C. V. do Couto E Silva, A obrigação... cit., p. 167.

${ }^{111}$ V., a respeito, C. FRIED, Contract as Promise - A Theory of Contractual Obligation, Cambridge, Harvard Press, 1981, p. 2 e ss.

${ }^{112}$ P. D. R. de ARAúJo, Prorrogação... cit., p. 64.
} 
Ressalve-se que o influxo do tempo nas relações negociais não evoluiu de modo isolado, mas sim em conjunto com o movimento pelo qual a relação obrigacional, como um todo, passou a ser apreendida de forma distinta. De um conceito estático, evoluiu-se para a denominada perspectiva dinâmica da obrigação.

Clóvis Do Couto SILva, declaradamente inspirado no alvitre de KARL LARENZ, entendeu que, sob uma visão moderna, a obrigação não podia mais ser estudada internamente quanto a sua estrutura, mas sim por sua função dinâmica ${ }^{113}$, ou seja, sua função perene no tempo/espaço.

Neste período, a alteração das circunstâncias, no decorrer do tempo, passou a ser, de uma vez por todas, objeto de maior atenção e estudo ${ }^{114}$. Diversas teorias são alçadas à condição de protagonistas nas relações contratuais prolongadas, como a da cláusula rebus sic stantibus e as demais dela decorrentes, a teoria da base objetiva do negócio jurídico, da pressuposição, da imprevisão, da onerosidade excessiva, etc. ${ }^{115}$

Ressalve-se, quanto a este aspecto, que o presente trabalho, sobre a possibilidade de prorrogação dos contratos, não se relaciona com a alteração das circunstâncias. Caso ocorram mudanças supervenientes à formação do contrato, o ordenamento prescreve outros mecanismos, muitos deles culminando com o direito à revisão ou resolução contratual.

A prorrogação compulsória do contrato, por sua vez, preconizada no art. 473, par. ún., do Código Civil efetiva-se com a consignação de prazo para atrasar os efeitos da denúncia da resilição unilateral contratual e, neste contexto, encontra-se o objeto ora

${ }^{113}$ Cf. A obrigação... cit., p. 167.

${ }^{114}$ Bem é verdade que a alteração das circunstâncias ganhou alguns apontamentos, não muito contundentes, já na tradição cultural greco-romana e, em maior ou menor grau de relevância, esteve presente nos estudos de glosadores, pós-glosadores, mormente nas Glosas de Acúrsio e nos Comentários de Bártolo, e ainda no direito comum europeu, desenrolando, contudo, papel de muito maior importância com o advento das grandes codificações do século XIX. V., a respeito, I. GALVÃo TELLES, Manual dos contratos em geral, $4^{\mathrm{a}}$ ed., Coimbra, Coimbra Ed., 2010, p. 37 e ss.

115 V., a respeito, P. D. R. de ARAúJO, Prorrogação... cit., p. 69: “Assim, em um período de aproximadamente cinquenta anos (entre 1890 e 1940), o pensamento jurídico evoluiu e com ele o conceito de tempo contratual. Abandonou-se a ideia de tempo único, linear e fixo, tido como um ponto na linha da história representando o momento da fusão entre oferta e aceitação das regras contratuais pelo surgimento de novas circunstâncias, pelo comportamento das partes após a celebração do contrato e, em certos casos, pelo surgimento de uma nova regra legal que afetasse os pactos já celebrados. Obviamente que essa revolução na teoria contratual teve seu maior impacto nos contratos que regiam relações jurídicas que se prolongavam no tempo, pois são essas as relações que mais estão sujeitas às surpresas do futuro". 
estudado e como será adiante explicitado, a alteração das circunstâncias, em regra, obstará a possibilidade de prorrogação compulsória do contrato.

PAUlO ARAÚJO ${ }^{116}$, ademais, debruçou-se sobre os contratos de longa duração, iniciando suas reflexões pela classificação de JUNQUEIRA DE AZEVEDO ${ }^{117}$.

Se o contrato não pode ser adimplido imediatamente, ou seja, se não é instantâneo, a satisfação do interesse do credor será realizada em um momento futuro, já estabelecido. O tempo é, portanto, um indicador do modo pelo qual a prestação deve ser cumprida. Existem três fenômenos distintos.

Fala-se em "execução diferida" quando a prestação requer inevitável período de tempo para ser cumprida, $v . g$., contrato de empreitada. O segundo caso é o da relação de trato sucessivo, quando o interesse do credor é satisfeito se a mesma prestação é repetida várias vezes, como em uma relação de fornecimento. Por último, verificam-se as hipóteses em que a execução é continuada, como, por exemplo, um contrato de depósito. Para satisfação do interesse, a prestação deve durar certo período de tempo.

Somente os últimos dois fenômenos (contrato de trato sucessivo e de execução continuada) são tecnicamente relações contratuais duradouras. Nestas ocasiões, o fator temporal é desejado. Faz parte do objeto do negócio jurídico ${ }^{118}$. Nas relações de execução diferida, todavia, o tempo é meramente um obstáculo para concreção do fim almejado. É suportado por uma ou todas as partes ${ }^{119}$.

\footnotetext{
${ }^{116}$ Prorrogação... cit., principalmente, p. 54-76.

${ }^{117}$ Natureza jurídica do contrato de consórcio (sinalagma direto). Onerosidade excessiva em contrato de consórcio. Resolução parcial do contrato, in Novos estudos e pareceres de Direito Privado, São Paulo, Saraiva, 2009, p. 356-357.

118 Cf. A. JUNQUEIRA DE AZEVEDO, Natureza jurídica... cit., 357: "Nas duas últimas hipóteses, o tempo corresponde ao "interesse na satisfação continuada de uma necessidade duradoura"; ele faz parte da causa final do contrato".

119 V., em sentido análogo, G. OPPO, I contratti di durata, in Rivista di diritto comerciale e del diritto generale delle obbligazioni, v. 41, Milão, F. Villardi, 1943, p. 154.
} 
Como lembra GiORgIO OPPO, não é a extensão do termo que qualifica a relação duradoura (o "contratto di durata"). É a execução da obrigação compatível aos interesses contratuais que estabelece o vínculo contratual duradouro, peculiar e digno de estudo ${ }^{120}$.

Existem, portanto, casos em que o termo acordado pelas partes é meramente elemento acidental do conteúdo do negócio. Em outras oportunidades, será formatado como elemento essencial do negócio, necessário à caracterização da relação contratual ${ }^{121}$.

A despeito de em ambos os negócios jurídicos o tempo ser considerado elemento essencial, a experiência prática aponta para certas diferenças entre os contratos em que a prestação é repetida diversas vezes (trato sucessivo) e aqueles em que uma prestação estende-se no tempo (execução continuada).

Em um contrato de trato sucessivo, o interesse das partes é percebido durante a execução do contrato. Por exemplo, em um contrato de distribuição, quando da realização da primeira entrega, já há satisfação parcial do interesse do credor ensejando parte do adimplemento.

Em uma relação de execução continuada, todavia, sem o decurso integral do período contratado, a obrigação pode estar absolutamente inadimplida. Considere-se um contrato de depósito de mobília por quinze dias. Se no penúltimo dia do termo contratual, o depositário denunciar o contrato e despejar os bens do depositante, estará caracterizado o integral inadimplemento da obrigação contratada.

Tais conclusões geram várias consequências, tanto na quantificação de perdas e danos em caso de reparação civil, quanto no cálculo de eventual multa contratual, que deve ser integralmente paga (impossível seria a redução equitativa como estabelece o art. 413 do Código Civil).

Some-se a isto, como bem ressalta ANNE-SOPHIE LABORDERIE ${ }^{122}$, que a doutrina francesa tem guardado distinta atenção à percepção de que o aspecto temporal, cada vez mais, influencia as relações jurídicas de modo cíclico, e não apenas linear. Em

\footnotetext{
${ }^{120}$ I contratti... cit., p. 154.

${ }^{121}$ Cf. I. Galvão Telles, Manual... cit., p. 279.

${ }^{122}$ La pérennité...cit.
} 
relações de trato sucessivo, nem sempre o conteúdo ou a periodicidade da prestação será uniforme.

Tome-se, por exemplo, qualquer relação contratual cujo programa obrigacional esteja condicionado à demanda do consumidor, $v . g$., a distribuição de água mineral engarrafada nos meses em que a temperatura se encontra mais elevada. Note-se que não se está cogitando do aumento do volume contratado durante o verão (pois a estação do ano é evento certo e periódico), mas o aumento do consumo, quando a temperatura de certa localidade está mais alta do que de constume.

Certamente, em uma relação como esta, o tempo exercerá influência de forma cíclica e não uniforme. O decurso da relação contratual estará permeado de momentos distintos de maior ou menor aproximação entre as partes.

Sendo assim, o intérprete, além de apreciar as premissas fáticas estabelecidas no art. 473, par. ún., do Código Civil: a "natureza do contrato” e a "natureza e vulto dos investimentos", também deverá ater-se ao momento da denúncia para eventualmente diagnosticar abusividade de direito.

Antes que se prossiga, alguns apontamentos sobre modernas teorias contatuais são necessários para um alargamento de premissas teóricas para, a final, apresentar conclusões sobre a resilição unilateral abusiva. 


\section{CAPÍTULO 3 - IMPLICAÇÕES DO PARADIGMA CONTRATUAL MODERNO E DAS NOVAS TEORIAS CONTRATUAIS SOBRE AS RELAÇÕES DE LONGA DURAÇÃO}

Tendo sido já estabelecidas as bases dogmáticas sobre a resilição unilateral abusiva, ínsita à vedação geral ao abuso de direito e também à latente influência do tempo nas relações contratuais duradouras, ainda que nem sempre observada de forma análoga, passa-se ao estudo de novas teorias contratuais.

Deve ser ressaltado, no entanto, que estas abordagens mais recentes não inovam a dogmática contemporânea advinda do paradigma contratual moderno, mas antes buscam fornecer ideias com o explícito escopo de auxiliar os estudiosos a interpretarem o ordenamento jurídico positivo.

Sendo assim, quando necessário, o intérprete buscando identificar a abusividade de certa conduta e, neste caso, da resilição unilateral, pode valer-se das seguintes reflexões.

\section{Seção I - Análise econômica do direito}

A denominada análise econômica do direito constitui temática que, cada vez mais, tem chamado a atenção de estudiosos. De procedência de trabalhos norte-americanos e britânicos, a perspectiva econômica busca proposições mais pragmáticas sem, contudo, criar tensão dialética com a dogmática.

Os primeiros estudos com esta abordagem, entre as décadas de 1920 e 1960, referiam-se, quase que exclusivamente ao direito concorrencial, mais especificamente sobre a regulação antitrust ${ }^{123}$.

A partir de então, a análise em apreço espraiou-se em direção a vários ramos do direito. No tocante ao direito contratual, esta realidade não é diferente.

${ }^{123}$ Cf. R. A. POSNER, Economic... cit., p. 25. Em igual sentido, G. CALABRESI, Inerpretazione giuridica e analisi economica (prefácio), coords. Guido Alpa, Francesco Pulitini et al., trad. it. Francesco Pulitini, Milão, Giuffrè, 1982, p. vii. A referência ao artigo de GUIDO CALABRESI está em língua italiana, pois, salvo engano, não há publicação do mesmo estudo em língua inglesa. 
Embora a análise econômica procure informar a sistemática de maior pragmatismo, não se deve olvidar de sua finalidade principal, qual seja a de emprestar maior eficiência econômica nas relações jurídicas, ou melhor, legitimar a tutela da maior eficiência ${ }^{124}$ nas relações jurídicas.

A seguinte indagação crítica é comumente formulada: a tutela da maior eficiência econômica é compatível com o escopo maior de um ordenamento jurídico, qual seja o de prover justiça distributiva aos jurisdicionados (suum cuique tribuere)?

GUIDO CALABRESI ${ }^{125}$, ao frisar que esta inquietação é corriqueira tanto em países de common law quanto de civil law, resume três principais respostas à interrogação (que também é lembrada por RICHARD POSNER: "The economic approach to law is criticized for ignoring 'justice,,,126).

A primeira resposta salienta que a abordagem econômica não é um "strumento critico o di riforma", mas pode ser utilizada para uma análise positiva de certas regras jurídicas. GUIDO CALABRESI, no entanto, afirma que até em uma avaliação minimalista como esta, a mera explicação de uma regra jurídica de nada vale se não sopesada com o denominado "escopo distributivo" das leis, o que nada mais é do que a necessidade de concessão de justiça distributiva.

Já a segunda resposta está atrelada à Escola de Chicago, como ficou notoriamente conhecida a teoria atribuída aos estudos e proposições de RONALD COASE e RICHARD POSNER, além de seus seguidores.

Para Guido CALABRESI, a Escola de Chicago teria embasado suas principais conjecturas na persecução da "eficiência na maximização da riqueza", permitindo toda e qualquer alteração possível para aumentar o lucro e diminuir o prejuízo. Tal proposição,

\footnotetext{
${ }^{124}$ Assim compreendida: "funcionar efetivamente com o menor desperdício de esforço" (I. MACNEIL, $O$ novo... cit., p. xviii).

${ }^{125}$ Cf. Interpretazione... cit., p. ix-xi.

${ }^{126}$ Cf. Economic... cit., p. 30. Em tradução livre: “A abordagem econômica do direito é criticada por ignorar a 'Justiça',.
} 
entretanto, por não declarar a relevância da justiça distributiva concretizaria um "sofisma" 127 .

Finalmente, a terceira resposta, segundo ainda GuIDO CALABRESI, é a ele atribuída e, em suma, reconhece que o escopo maior e primordial do ordenamento sempre será o de conceder justiça distributiva ${ }^{128}$. Todavia, a tutela da eficiência pode e deve ser almejada quando não afrontar o "escopo distributivo", ou seja, se possível, deve a lei ou a interpretação da lei perseguir maior eficiência econômica, mas sem afetar seu escopo principal e, sendo assim, em determinadas situações, a lei, ao alinhar-se com sua finalidade última, poderá revelar inevitável ineficiência econômica ${ }^{129}$.

Provavelmente, a terceira resposta é a que melhor adapta-se ao paradigma moderno. Buscar eficiência econômica nas relações jurídicas é, sem dúvida, uma abordagem que deve ser estudada, mas jamais afastando a lei da justiça.

Para os fins deste estudo, reputam-se suficientes estas ideias sobre a análise econômica do direito para explicitar que desde há muito os estudiosos procuram o necessário e adequado equilíbrio entre economia e direito. Em seguida, passa-se ao estudo de algumas noções sobre a análise econômica aplicada ao domínio dos contratos.

\section{Seção II - Análise econômica do direito no âmbito do contrato}

A respeito dos escopos reservados à análise econômica quando transportada ao campo do contratos, RICHARD POSNER, recordando, mais uma vez, que o objetivo desta abordagem é o de incrementar com maior praticidade a respectiva disciplina, propôs cinco finalidades particulares, quais sejam: (i) prevenir condutas oportunistas; (ii) intercalar cláusulas contratuais eficientes; (iii) prevenir erros evitáveis durante o processo de

\footnotetext{
${ }^{127}$ V. Interpretazione... cit., p. ix.
}

${ }^{128}$ Lembre-se, a respeito da igualdade substancial, a célebre lição de R. BARBOSA, Oração aos moços, São Paulo, Papagaio, 2003, p. 26 : “A regra da igualdade não consiste senão em quinhoar desigualmente aos desiguais, na medida em que se desigualam. Nesta desigualdade social, proporcionada à desigualdade natural, é que se acha a verdadeira lei da igualdade. O mais são desvarios da inveja, do orgulho, ou da loucura. Tratar com desigualdade a iguais, ou a desiguais com igualdade, seria desigualdade flagrante, $e$ não igualdade real”.

${ }^{129}$ Cf. Interpretazione... cit., p. ix: "Così una legge "efficiente” può senz'altro essere attaccata perchè un cambiamento è desiderabile dal punto di vista distributivo, anche se il cambiamento può rísolversi in una legge inefficiente”. Em tradução livre: “Assim, uma lei 'eficiente' pode certamente ser atacada por uma alteração desejada do ponto de vista distributivo, ainda que a alteração possa resultar em uma lei ineficiente". 
contratação; (iv) alocar risco para a parte em melhor condição de suportá-lo; e, ainda, (v) reduzir o custo de solução de conflitos ${ }^{130}$.

É forçoso ressaltar, desde já, que a teoria imersa em doutrinas de países do common law, expõe, por vezes, uma série de proposições que, em ordenamentos jurídicos como o brasileiro, usualmente, são verificadas em outros institutos jurídicos previstos na legislação.

Observe-se a primeira finalidade proposta por RICHARD POSNER ("prevenir condutas oportunistas"). Tal objetivo é ilustrado pelos seguintes exemplos: um pescador contratado para pescar certa quantidade de peixes, quando já se encontra em alto mar, alerta o contratante que só procederá ao cumprimento do contrato se o preço for incrementado; ou então um fornecedor de gelo que, por força de uma imprevista temporada de alto calor, deve arcar com sensível aumento dos seus custos de produção, e, por isso, interpela o comprador, esclarecendo que será necessário um aumento do preço.

Pela análise econômica, a conduta do pescador seria antijurídica na medida em que não haveria motivos a justificar a exigência de aumento do preço, ao passo que o comportamento do fornecedor de gelo seria embasado por fatos imprevistos. A distinção está no fato de que o pescador poderia adimplir o contrato da forma como acordado, ao passo que o fornecedor de gelo não mais poderia cumprir suas obrigações a contento. Logo, a pretensão do fornecedor em revisar o contrato seria abusiva ${ }^{131}$.

Tais constatações não são falaciosas, mas procuram encontrar ou justificar soluções jurídicas por fundamentos mais pragmáticos dispensando, contudo, a conceituação de institutos jurídicos desde há muito sedimentados pela cultura jurídica da Europa continental.

Quanto aos exemplos de RICHARD POSNER, não parece ser necessária ulterior interpretação se não pela noção de anulabilidade do negócio jurídico por dolo, no caso do pescador; e alteração das circunstâncias, no exemplo do fornecedor de gelo.

\footnotetext{
${ }^{130}$ V. Economic... cit., p. 108.

${ }^{131}$ V. Economic... cit., p. 110-111.
} 
Tenha-se presente que o estudo da análise econômica do direito, não muito frequente entre nós, deve ser considerado pela sua inequívoca importância.

Em monografia específica, FERNANDO ARAÚJo, valendo-se, declaradamente, da exposição de RoBert COOTER e THOMAs Ullen, sugere alguns objetivos da análise econômica na órbita dos contratos, a saber::

“1. Promover a cooperação através da conversão de jogos nãocooperativos em jogos cooperativos. 2. Promover a circulação e partilha da informação entre as partes num contrato. 3. Incentivar a vinculação óptima ao contrato. 4. Incentivar o nível óptimo de confiança. 5. Diminuir custos de transação através da multiplicação de normas supletivas. 6. Fomentar as interdependências duradouras e diminuir a necessidade de estipulações contratuais explícitas." ${ }^{132}$

Para efetivação destas finalidades, ainda segundo o autor, é indispensável a implementação das seguintes tarefas:

"1. A fixação do conteúdo substantivo das regras contratuais; 2. A determinação do grau de flexibilidade e supletividade dessas regras; 3. A regulação da margem de renegociação que permita contornar essas regras." 133

À toda evidência, os fins perseguidos pela análise econômica são muito mais relevantes quando a atenção é concentrada nos contratos de longa duração, relações em que a inexorabilidade do tempo (provavelmente) estimula as partes a flexibilizarem suas condutas buscando auferir a maior eficiência possível do contrato.

Ainda uma vez, vale a ressalva de que o tema ora estudado não se relaciona com o que comumente é concebido como alteração das circunstâncias. A despeito da sistemática da cláusula rebus sic stantibus e das teorias dela decorrentes, tais como a teoria da pressuposição, a frustração dos fins do contrato ou a base objetiva do negócio jurídico

\footnotetext{
${ }^{132}$ Uma análise económica dos contratos - Parte I: A abordagem económica, a responsabilidade e a tutela dos interesses contratuais, in Revista de Direito Público e Economia - RDPE, Belo Horizonte, ano 5, n. 18, 2007, p. 72. V., também, R. COOTER e T. UlLEN, Law and Economics, $5^{\mathrm{a}}$ ed., trad. port. Luis Marcos Sander e Francisco Araújo da Costa, Porto Alegre, Bookman, 2010, p. 208-247.

${ }^{133}$ Uma análise... cit., p. 72.
} 
ou de outras tantas, existem vicissitudes inerentes às relações contratuais duradouras que recorrentemente demandam flexibilização na atuação dos contratantes. Este fundamento nada mais significa do que reconhecer a maior incidência de riscos quando a relação se estende no tempo ${ }^{134}$.

De tudo, o mais importante é restar claro que esta flexibilização ou até uma renegociação contratual, não tem o condão de suprir um desequilíbrio instaurado pela alteração da circunstância, mas sim otimizar a alocação de recursos delineada pelo instrumento contratual.

Desse modo, para discorrer sobre as funções precípuas da análise econômica no domínio dos contratos, torna-se mais didática a divisão nos subsequentes itens: a) o "paradoxo da indenização" e os incentivos ao adimplemento; b) economia dos custos de transação; e, ainda, (c) teoria dos contratos incompletos.

\section{a) o "paradoxo da indenização" e os incentivos ao adimplemento}

A primeira premissa do "paradoxo da indenização", 135 , em suma, indica que as escolhas dos contratantes (objetivando o maior benefício possível), são influenciadas pela extensão da responsabilidade pelo descumprimento da obrigação.

Para o devedor, caso a indenização supere os custos que incorrerá para adimplir o contrato, haverá estímulo ao adimplemento. Para o credor, se a indenização for inferior ao benefício esperado, haverá tendência à cooperação, que será despicienda quando a reparação pecuniária superar o benefício almejado.

Há, portanto, um paradoxo na medida em que a maior ou menor indenização incentiva uma parte e desestimula a outra ${ }^{136}$.

\footnotetext{
${ }^{134}$ Cf. F. ARAÚJO, Uma análise... cit., p. 83: “O tempo que medeia a formação dos contratos, por um lado, $e$ a verificação do seu cabal cumprimento, ou incumprimento, por outro, faz aumentar proporcionalmente os riscos - seja as contingências internas e externas susceptíveis de perturbarem o relacionamento das partes, seja os riscos de degeneração oportunista da conduta devida por cada uma das partes à outra - e daí que a juridicidade do vínculo contratual, a exigibilidade judicial do comportamento devido, a susceptibilidade de indemnização por frustração do crédito, estejam correlacionados com a duração dos contratos e com a sedimentação, através deles, dos nexos de interdependência económica”.

${ }^{135}$ V., por todos, F. ARAúJo, Uma análise económica dos contratos Parte II: O "paradoxo da indenização", a tutela da confiança, a flexibilização da responsabilidade contratual, in Revista de Direito Público da Economia RDPE, Belo Horizonte, ano 5, n. 19, 2007, p. 67-73.
} 
Antes de pensar na boa-fé subjetiva das partes ou no interesse no cumprimento do contrato, volta-se a atenção para as opções da parte diante do contrato. Haverá consequências para o descumprimento? E, se mesmo com tais consequências, ainda assim, o descumprimento for mais lucrativo do que adimplir?

Imagine-se uma relação contratual de longa duração em que exista uma grande transferência de know how. Provavelmente, se convencionada a possibilidade de resilição, também estaria prevista uma multa por denúncia antecipada do contrato. Ese, em dado momento, a parte que recebeu o know how decidir pagar a multa, denunciar o contrato e extinguir a relação contratual, pois, desta forma, entende que seus lucros seriam maximizados, já que poderia passar a empreender este know how em outra operação? A resposta a tal pergunta encontra-se precisamente na compatibilização do período de aviso prévio e os investimentos da parte denunciada, ainda que seja necessária a prorrogação por determinação judicial, como será adiante considerado.

Segundo a doutrina de Robert COOTER e THOMAS UlLEN, somente quando o benefício com o cumprimento for menor do que o prejuízo com o descumprimento, haverá um ambiente cooperativo digno de celebração (ou manutenção) de um contrato: " $O$ compromisso é alcançado excluindo a oportunidade de apropriar-se. A oportunidade de apropriar-se é excluída pelo alto custo da responsabilidade civil em caso de quebra do contrato."

Daí o primeiro escopo precípuo da análise econômica no domínio dos contratos: "a primeira finalidade do direito contratual é possibilitar que as pessoas convertam jogos com soluções ineficientes em jogos com soluções eficientes"138.

Já no que toca à segunda finalidade, qual seja, a de promover a circulação e a partilha de informações entre as partes, é necessário lembrar que a análise econômica está sempre calcada na percepção de que as informações entre contratantes são assimétricas. $O$ vendedor de carro possui informações muito mais acuradas do que o consumidor. A

\footnotetext{
${ }^{136}$ Nas palavras de F. ARAúJo, Uma análise... cit.: p. 70: "O paradoxo da indemnização" consiste, em síntese, no facto de que, quanto mais elevada for a indemnização, maior é o incentivo de eficiência do devedor, menor o do credor, e que quanto mais baixa for a indemnização, menor é o incentivo de eficiência do devedor e maior o do credor. A eficiência do devedor e do credor, são, pois, incentivadas em sentidos opostos por um só regime indemnizatório”.

${ }^{137}$ Law and... cit., p. 211.

${ }^{138}$ R. COOTER e T. UlLEN, Law and.... cit., p. 211.
} 
solução, no entanto, não está simplesmente em obrigar o vendedor a fornecer toda e qualquer informação, até porque o consumidor certamente não assimilará todos os detalhes técnicos conhecidos pelo vendedor ${ }^{139}$.

Sendo assim, outra premissa da análise econômica pode ser resumida nos seguintes termos: "a presença de informações assimétricas pode impedir que aconteçam trocas que, de outra forma, seriam mutuamente benéficas." ${ }^{140}$ Por esta premissa justificase o objetivo de buscar partilha e circulação eficiente de informações.

Para exemplificar, pode-se aludir ao chamado dilema do prisioneiro, exemplo célebre e frequentemente citado em manuais de matemática, economia e, hodiernamente, direito:

Dois prisioneiros estão em distintas salas sem qualquer possibilidade de comunicação entre si. A ambos é proposto idêntico acordo pelo qual é facultado assumir certo crime ou delatar o outro indiciado. Um prisioneiro será apenado com pena máxima se assumir o crime, e ainda for acusado pelo outro, o qual será punido com pena média. Se ambos se acusarem, a pena será média para os dois. Se o crime for assumido por ambos, a sanção mínima será igualmente aplicada.

Sendo assim, a assunção do crime pode implicar pena máxima se o outro delatar, ou pena mínima se o outro assumir. A delação, por sua vez, levará à pena média, não importando a conduta do outro.

Partindo da premissa de que ambos são agentes racionais, nos limites das informações que dispunham (ou não dispunham), os dois indiciados acabam por escolher a delação, garantindo a pena média. Obviamente, se pudessem trocar informações (desde que em um ambiente de confiança - cooperativo), ambos assumiriam o crime, recebendo, por consequência, a pena mínima.

O que se depreende deste dilema é que a troca de informações em um ambiente de confiança e racionalidade (cooperação), tende a produzir resultado mais proveitoso possível (eficiente), qual seja, a pena mínima.

\footnotetext{
${ }^{139} \mathrm{~V}$., a respeito, F. L. TOKARS, Assimetria informacional, in $O$ que é análise econômica do direito, coords. Maria Clara Pereira Barreto e Vinicius Klein, Belo Horizonte, Fórum, 2011, p. 89-95.

${ }^{140}$ R. COOTER e T. UlLEN, Law and.... cit., p. 213.
} 
Esta solução é facilmente transportada para a disciplina contratual. Para a análise econômica, a concreção de suas finalidades, em prol da maior eficiência, pode ser promovida pelo direito, considerada a estratégia contratual adotada.

Mais uma vez, com base no ensinamento de FERnANDo ARAÚJo, ilustra-se a conclusão sobre o ponto:

"Vemos assim como o direito tem a virtualidade de promover as transacções eficientes, convertendo um jogo não-cooperativo num jogo cooperativo, por simples alteração do quadro de incentivos disponíveis para as partes"141

Resta explicar o que vem a ser uma "simples alteração do quadro de incentivos disponíveis para as partes". Para tanto, utiliza-se do seguinte exemplo: em uma dada relação contratual duradoura, um fornecedor incorre em certos custos para cumprir suas obrigações contratuais, recebendo, em contrapartida, preço maior do que os custos despendidos. Daí seu interesse na manutenção do vínculo.

O credor, por sua vez, recebe o fornecimento de mercadorias, mas arca com o pagamento do preço. Ocorre que o benefício com o fornecimento de mercadorias é maior do que o preço pago. Daí o seu interesse.

Ademais, no contrato há cláusula dispondo sobre multa compensatória em caso de resilição imotivada de quaisquer das partes. A quantia desta multa corresponde, todavia, precisamente ao benefício auferido pelo comprador (i. e., convencionou-se a possibilidade de indenização suplementar - art. 416, par. ún., do Código Civil). Desta forma, não há muita apreensão da parte do comprador quanto ao inadimplemento do fornecedor, ou seja, o contrato não estimula a cooperação do comprador e, consequentemente, a partilha de informações.

O dever de cooperação ou a troca de informações, pela análise econômica, decorre, portanto, do próprio estímulo proveniente do contrato. Se o agente racional atingirá o mesmo benefício em caso de adimplemento ou inadimplemento, não há motivos para o sistema reagir contra sua atuação não-cooperativa. $\mathrm{O}$ fornecedor, agente igualmente

${ }^{141}$ F. ARAÚJo, Uma análise... cit., p. 87. 
racional, desejou suportar a multa que, em última análise, para o comprador, substituía o próprio adimplemento.

A mesma realidade pode ser observada na ótica do fornecedor, se a multa por descumprimento contratual for convencionada em valor aquém do benefício que espera auferir do contrato, não há estímulo para o adimplemento.

Desse modo, o contrato quando bem equacionado, pode estimular os contratantes à cooperação e a consequente partilha de informações, implicando maior eficiência possível com a alocação de recursos.

Observe-se, a propósito, que tal análise econômica é perfeitamente compatível com a admissão do abuso de direito prescindível de culpa, pois se compreende a falta de cooperação do contratante por decorrência direta da falta de estímulo. Não há necessidade de aferir a inobservância de qualquer dever de cuidado, mas tão somente o descompasso entre o exercício do direito (p. ex.: troca de informações) e os limites ex vi do art. 187 do Código Civil.

Ainda, de modo ainda mais latente no que diz respeito aos contratos de longa duração, também se deve levar em consideração o que FERNANDO ARAÚJO denomina "redução progressiva da tutela indenizatória".

Nos contratos de longa duração, as cláusulas sobre o valor da indenização produzem um efeito indireto no interesse das partes no cumprimento do contrato. Conforme a seguinte explicação exemplificativa ${ }^{142}$, é válido trabalhar certas proposições, a saber:

- em um contrato de empreitada, é sabido que os custos do empreiteiro para execução da obra serão de R \$ 9.000,00; sabe-se também que estas despesas serão exigidas no decorrer da obra ( $\mathrm{R} \$ 2.000,00$ no início; $\mathrm{R}$ \$ 4.000,00 na parte intermediária; e R \$ 3.000,00 na conclusão dos trabalhos);

- para execução do trabalho, convencionou-se o preço de R\$ $11.000,00$ e determinou-se data específica para execução dos trabalhos.

${ }^{142}$ F. ARAúJo, Uma análise... cit., p. 103-105. 
Neste cenário, se a indenização para o descumprimento total do contrato for a totalidade do preço a ser pago $(\mathrm{R} \$ 11.000,00)$, o credor, ainda que deseje o cumprimento do contrato, estará garantido de prejuízo maior, na medida em que lhe será devido R\$ 22.000,00 (restituição do preço e reparação civil).

A indenização, por outro lado, pode ser condicionada à fase de execução em que o contrato se encontra. Por exemplo: caso o empreiteiro não cumpra nem a fase inicial do acordado, a indenização será $\mathrm{R}$ \$3.000,00 (maior do que o custo de execução - R \$ 2.000,00). Analogamente, nas outras fases, a indenização deverá sempre ser um pouco maior do que os custos de execução. Desse modo, há incentivo para que o devedor cumpra o contrato, mas a indenização não é interessante para o credor. Por exemplo: caso o contrato seja descumprido na fase final, a indenização seria não muito maior do que $\mathrm{R} \$$ $3.000,00$ (custos previstos para fase final).

Conclui-se, em vista do acima aduzido, que na segunda hipótese o credor tem maior interesse no cumprimento do contrato. Já na ótica do devedor, será ainda mais rentável executar o contrato (há incentivo econômico), todavia sua responsabilidade, no decorrer do tempo, é decrescente, circunstância que pode gerar consequência até no preço. Idealmente, atinge-se um preço menor (pois, o risco do devedor é menor) e uma maior cooperação (pois, a indenização não é tão lucrativa para o credor).

Ademais, em que pese a influência da potencial indenização na esfera jurídica do devedor, o incentivo à cooperação na ótica do credor já seria algo positivo. Nas palavras de FERNANDO ARAúJO:

"Enfatizámos já repetidamente o quanto o cumprimento eficiente pode depender da colaboração do credor, dos seus investimentos "em confiança", da sua partilha de informação com o devedor, do seu desempenho de alguns devedores acessórios, do cumprimento dos seus próprios deveres básicos no seio do contrato (se esse contrato for bilateral).

Podemos agora visualizar o modo como a responsabilidade decrescente do devedor (em função de despesas efectivamente incorridas por ele), fazendo o credor receber cada vez menos à medida que se 
aproxima o momento do vencimento, pode constituir um incentivo económico àquela colaboração - e um incentivo crescente."143

No exemplo acima reproduzido, é indubitável que o contrato analisado seria de execução diferida, hipótese em que a possibilidade do vínculo jurídico ser extinto por denúncia contratual é rara.

Em um contrato de empreitada, seria um tanto inusitado estipular a possibilidade de denúncia unilateral pelo empreiteiro, pois sua obrigação é uma só. Trabalhar para a construção da coisa.

Não obstante, o exemplo é proveitoso na medida em que fixa noções sobre os estímulos ao adimplemento e, por via reflexa, à cooperação, partilha de informações e aos investimentos em confiança.

Não se distanciando dos parâmetros éticos e sociais do ordenamento, pelos quais, a rigor, está lastreado o dever de respeitar um padrão esperado de conduta em consonância com a boa-fé e os bons costumes, as partes contratantes estão vinculadas às implicações econômicas de suas atitudes, ainda que, para maximizar eficiência, atravessem a fronteira da licitude.

Neste sentido, o dito paradoxo da indenização acrescenta parâmetros pragmáticos à análise do comportamento das partes.

Finalmente, é possível deduzir ulterior conclusão especificamente sobre a possibilidade de prorrogação compulsória. Se uma das funções do direito, ainda que sob viés econômico, é a de promover maior eficiência na alocação de recursos, a própria tutela de prorrogação compulsória incentiva a vinculação das partes ao contrato, ou seja, incentiva a execução direta das obrigações.

Com a maior disseminação dos significativos efeitos produzidos pela introdução do art. 473, par. ún., do Código Civil, impulsiona-se o contratante a emitir sua escolha não mais inserido no dilema adimplemento/reparação, mas sim na dicotomia adimplemento/prorrogação compulsória.

${ }^{143}$ F. ARAúJo, Uma análise... cit., p. 103. 
Ainda mais porque possivelmente será menos oneroso e, certamente, menos arriscado, manter-se vinculado à relação contratual por livre vontade e não por determinação judicial, hipótese em que, por exemplo, o juiz pode especificar a forma, modo e tempo da obrigação forçada, eliminando maiores chances de flexibilidade no cumprimento da obrigação. Seria este o paradoxo da prorrogação?

Apresentadas estas ideias sobre incentivos ao cumprimento eficiente do contrato, frise-se que a análise econômica do direito está em tudo atrelada à evidência dos chamados custos de transação, os quais são de suma importância para verificar “investimentos consideráveis" diante de uma hipótese de prorrogação judicial do contrato.

\section{b) economia dos custos de transação}

Sobre a análise dos custos de transação (transaction costs analysis), o estudo de RoNALD COASE, precursor da teoria da firma, é de suma importância para o surgimento do conceito e, mais tarde, da a teoria difundida por todo o mundo ocidental. Não por outro motivo, faz-se necessária uma análise introdutória sobre as ideias disseminadas pelo economista.

Em uma troca simples, os custos de transação são aferíveis no próprio momento da troca. Se um dos contratantes incorrer em custo desproporcional em relação ao proveito obtido, resta evidente a excessiva onerosidade, a qual é repudiada pelo sistema (se advinda de algo antijurídico).

Já nas relações contínuas, o problema encerra maior complexidade. Por ora, basta lembrar que, nesta espécie, os custos de transação não são aferíveis em momento estático.

Os custos de transação qualificam-se, portanto, como as despesas necessárias para manter e utilizar os direitos de propriedade, ou seja, para alocar recursos mediante trocas, como, por exemplo, custos com "redação de contratos, de monitoramento $e$ imposição de contratos, de acesso a informação, etc." ${ }^{\prime 144}$.

${ }^{144}$ Cf. V. KLeIN, Teorema de Coase, in $O$ que é análise econômica do direito, coords. Maria Clara Pereira Barreto e Vinicius Klein, Belo Horizonte, Fórum, 2011, p. 72. 
O exemplo inicial de RONALD COASE é o de uma fábrica de cigarros que provoca poluição nos bairros do entorno. As soluções ínsitas ao problema, segundo o paradigma comum, seriam: responsabilizar o fabricante por danos causados ou, alternativamente, incrementar os tributos à produção e, finalmente, para erradicar o problema, proibir a instalação de um parque fabril da indústria tabagista em uma região de bairros residenciais $^{145}$.

Desta forma, seria a poluição uma externalidade à finalidade econômica da indústria. Para coibi-la, adaptá-la, diminuí-la, ou, valendo-se da expressão comumente empregada na linguagem econômica, para a "internalização da externalidade", haverá certos custos.

O contrato, na qualidade de veículo que possibilita a alocação consensual de recursos entre duas ou mais partes, obviamente, não está avesso ao fenômeno das externalidades.

Ainda, como mencionado na introdução deste trabalho, as partes não desejam apenas qualquer alocação de recursos, mas sim aquela mais eficiente possível (desde que permitida ou não defesa em lei).

Naturalmente, pode ocorrer (e, de fato, ocorre a todo tempo) um choque entre a externalidade e a desejada eficiência do contrato em vigor. Não obstante, salvo nos casos das externalidades negativas radicais ${ }^{146}$ (danos graves à saúde, meio ambiente, etc.), há possibilidade de contornar a adversidade.

Em relações contratuais instantâneas, eventual externalidade pode ser facilmente resolvida no ato da celebração. Se, por exemplo, na compra e venda de um automóvel, a mercadoria deve ser transportada de um local distante até a concessionária por uma rodovia em péssimas condições, o risco de danos ao veículo do transporte é, usualmente, alocado à vendedora.

Certamente, a vendedora tomará cuidados especiais para que a mercadoria não seja danificada no transporte. Para tanto, incorrerá em certos custos.

\footnotetext{
${ }^{145}$ V., a respeito, The Problem of Social Costs, in The Journal of Law and Economics, v. 3, 1960, p. 1.

${ }^{146}$ F. ARAUJO, Teoria... cit., p. 514.
} 
Nas relações contínuas, por sua vez, as externalidades podem surgir a qualquer tempo e podem ser mais ou menos previsíveis, de modo que a única maneira de internalizar a externalidade é pelo consentimento ex ante ou ex post de parte a parte para eliminar ou, pelo menos, minimizar o problema.

Frise-se, também, que muitas vezes a internalização da externalidade é maior do que o benefício (o resultado da alocação eficiente) esperado. Poder-se-ia pensar que melhor alternativa não há do que a extinção da relação contratual.

É preciso ter presente, contudo, a função jurídica precípua do contrato: estipulação das obrigações necessárias para a alocação eficiente de recursos. Assim, frente a uma externalidade negativa, duas poderão ser as possíveis resoluções.

A externalidade pode não estar atrelada a qualquer das partes e, por isto, sem o consentimento ex post de ambas, ela subsistirá de modo a obstar a desejada eficiência. Ou a externalidade estará em conflito com a obrigação de uma parte e esta terá o dever jurídico de internalizá-la, sob pena de caracterizar o seu inadimplemento.

O consentimento mútuo entre as partes sobre o modo de internalizar uma externalidade muitas vezes depende de tratativas ex post, uma vez que, como lembra RICHARD POSNER, quanto mais improvável for aquilo que pode atrapalhar a eficiência do contrato, menor as chances de as partes previamente incorrerem em custos para estipular quais seriam as obrigações diante da nova circunstância ${ }^{147}$.

A externalidade pode ser resolvida se equilibrado o interesse da vítima com o interesse econômico do explorador da atividade, salvo nos casos de externalidade negativa radical, que sempre deve ser eliminada ${ }^{148}$.

Em um significativo exemplo de FERNANDO ARAÚJO uma funilaria cujos ruídos incomodam os vizinhos, o prestador do serviço pode indenizar a vítima pelo prejuízo sofrido; ambos podem cofinanciar a instalação de aparelhos antirruído ou cofinanciar nova

\footnotetext{
${ }^{147}$ Economic... cit., p. 105.

${ }^{148}$ F. ARAÚJO, Introdução à economia, Lisboa, Almedina, 2002, p. 514.
} 
moradia para a vítima em lugar mais afastado ou, ainda, o cofinanciamento de nova oficina em outra localidade, etc. ${ }^{149}$.

O "Teorema de Coase", destarte, parte da premissa de que, no mundo negocial ideal, não haveria maiores conflitos na solução de externalidade não fossem os custos de transação. A formulação mais conhecida, como lembra VINICIUS KLEIN, é assim resumida: "numa situação de custos de transação zero, a alocação final de um bem, obtida por meio da barganha entre as partes, será sempre eficiente, não importa a configuração legal acerca da propriedade desse bem."150

Já sobre o mundo real em que sempre existirão custos de transação, o "Teorema de Coase" pode ser dividido em duas hipóteses: a da eficiência e a da invariância, assim definidas por VINICIUS KLEIN: “A hipótese da eficiência afirma que as partes sempre são capazes de chegar a um acordo que corresponde a solução eficiente para a situação. A hipótese da invariância afirma que essa solução será sempre alcançada, não importando como a responsabilidade legal esteja disposta."

Outra conclusão natural diz respeito à preocupação eminentemente interna corporis. A eficiência desejada (possível) pode ser alcançada diante de qualquer conflito, solucionável pela via de negociação. Há, sem dúvida, em prol do sucesso da autodisciplina institucionalizada sustentável, um isolamento do contrato. Com certo exagero, pode-se dizer que nenhum fator exógeno interfere na saúde contratual, desde que haja espaço para renegociação que demandem aceitáveis custos de transação ${ }^{152}$.

Tais conclusões podem ser ilustradas por mais um exemplo do próprio FERNANDO ARAÚJO: uma linha férrea passa pelo meio de um rebanho de gado de modo a prejudicar o pasto e causar acidentes. O valor do rebanho é R $\$ 100,00$. O custo para a construção de uma cerca de proteção é R \$ 150,00. Logo, seria menos custoso comprar o rebanho.

\footnotetext{
${ }^{149}$ F. ARAÚJo, Introdução... cit., p. 515.

${ }^{150}$ Teorema de... cit., p. 71.

${ }^{151}$ Teorema de... cit., p. 74.

${ }^{152}$ F. ARAÚJO, Teoria... cit., p. 210.
} 
Ademais, caso fosse construída a cerca, o rebanho teria um incremento em seu valor, pois o risco de interferência pela passagem dos trens seria extinto.

A companhia férrea poderia comprar o rebanho por $\mathrm{R} \$ 100,00$, mas se a construção da cerca (por $\mathrm{R} \$ 150,00$ ) aumentar o valor do rebanho para mais de $\mathrm{R} \$ 150,00$, por exemplo $\mathrm{R} \$ 151,00$, seria mais eficiente comprar o rebanho e, ainda assim, construir a cerca $(\mathrm{R} \$ 100,00+\mathrm{R} \$ 150,00-\mathrm{R} \$ 151,00=\mathrm{R} \$ 99,00-$ despesa total menor do que $\mathrm{R} \$$ $100,00)$.

Se, contudo, o valor do rebanho não ultrapassar $\mathrm{R} \$ 150,00$, a solução menos custosa é a compra do rebanho por $\mathrm{R} \$ 100,00^{153}$.

Note-se que não havendo onerosidade na negociação, a solução espontânea é de fácil percepção. Ocorre que, como é sabido, existem custos de transação, os quais obstam a solução natural e, idealmente, menos onerosa. Conclui-se, assim, não fossem os custos de transação ${ }^{154}$, que as externalidades poderiam ser espontaneamente negociadas, sem socorro à solução imposta.

Em um universo ideal, sem custos de transação, a solução mais eficiente sempre dar-se-ia após a negociação, qualquer fosse o número de externalidades. Qualquer um estaria disposto a pagar pela internalização da externalidade enquanto o prejuízo advindo da externalidade fosse superior ao custo de internizá-la ${ }^{155}$.

Este, em suma, é o teorema de RonAld COASE. Certamente, ele refere-se exclusivamente à produção máxima de eficiência, não necessariamente à solução mais concretamente justa ou, até, desejada.

Aplicando este raciocínio à lógica dos contratos, os direitos (por exemplo, de passagem da companhia férrea ou do proprietário do rebanho) são inicialmente atribuídos a cada parte. Assim, sabe-se quem deverá lidar com a externalidade negativa.

\footnotetext{
${ }^{153}$ F. ARAÚJO, Introdução... cit., p. 516.

${ }^{154}$ Na definição de F. ARAÚJO: "Lembremos que, por definição, "custos de transação" são todos aqueles em que se incorre na troca de utilidades e na afectação comutativa de recursos, quando se busca uma contraparte, se negocia com ela, se preveem e supervisionam as contingências do cumprimento, etc. - sendo que se podem subsumir à categoria mais geral os custos de busca de oportunidades de troca, os custos de negociação e os custos de cumprimento dos contratos -." (Introdução... cit., p. 517).

${ }^{155}$ F. ARAÚJO, Introdução... cit., p. 517.
} 
Quando disposições contratuais são definidas, é possível (ou, deve ser possível) estabelecer quais obrigações tocam a cada parte. Desta forma, se uma externalidade negativa interferir nesta ou naquela obrigação, a parte obrigada por ela é que estará adstrita ao infortúnio. Por exemplo, se a estrada deteriora-se, é o transportador que arca com as consequências desta externalidade e não o emitente do contrato de transporte. É o transportador que suporta os custos para contornar a adversidade.

Pois bem, no mundo real, há tendência para a solução espontânea quando o prejuízo decorrente da externalidade negativa for maior do que o custo para solucionar o problema, levando em consideração os custos de negociar, ceder, equilibrar interesses, enfim, qualquer peculiaridade ínsita aos custos de transação ${ }^{156}$.

Já quando os custos de transação para solucionar o contratempo são maiores do que o prejuízo causado, há tendência ao término ou alteração da relação. Muitas vezes, um processo judicial pode ser suportado pela parte, exatamente pela crença de que o custo para circundar a externalidade é maior do que o de sucumbir aos seus efeitos.

Observe-se, por oportuno, que, muitas vezes, a situação fática não será exclusivamente sobre uma externalidade, mas sim acerca de uma série delas. $\mathrm{O}$ tributo que é majorado, o fornecedor que incrementa o preço, a nova lei que proíbe certa conduta, etc.

Os custos de transação, portanto, quando superiores ao custo de internalização das externalidades, obstam o bem-estar mediante as trocas voluntárias que assegurariam o bem-estar máximo, implicando a execução imposta pelo Estado - "uma solução sucedânea e com riscos, mas mesmo assim preferível à pura ausência de trocas" ${ }^{\prime 157}$.

Ressalte-se, ainda, que não se pode resumir a análise econômica do direito à teoria dos custos de transação. Existem novas questões teóricas como a teoria dos property rights, novas teorias da empresa e a teoria da agência, esta última merecedora de alguns esclarecimentos $^{158}$.

\footnotetext{
${ }^{156}$ F. ARAÚJO, Introdução... cit., p. 519.

${ }^{157}$ F. ARAÚJO, Introdução... cit., p. 520.

${ }^{158}$ F. ARAÚJO, Teoria... cit., p. 211.
} 
Igualmente sujeita à influência do neoinstitucionalismo, a teoria da agência ("Positive Agency Theorie") está em gradativa ascensão. Diante da teoria dos custos de transação existem congruências, sem prejuízo de significativas diferenças - "um misto de complementaridade e rivalidade teórica" ${ }^{\prime 159}$.

Pela teoria da agência, é necessária uma análise dos custos verificados dentro de uma empresa. É sabido que, ante a escassez de recursos, a empresa necessita contratar para alocar recursos. Ademais, é claro que a empresa está organizada por indivíduos, quais sejam os proprietários, administradores, gestores, empregados e terceirizados. Ocorre que quase nunca haverá identidade entre as preferências pessoais de todos os indivíduos.

Em outras palavras, o interesse do principal (aquele que define o objetivo a ser perseguido) nem sempre estará simétrico à conduta do agente (aquele que age para concretizar o objetivo previamente delineado) ${ }^{160}$.

A expressão principal-agente não é muito comum na literatura jurídica, embora seja há tempos conhecida em estudos de economia. Para dirimir qualquer dúvida, esclareça-se que o principal é aquele que exerce poder hierárquico sobre o agente. Por definição, o maior exemplo de relação agente-principal é a relação trabalhista entre empregador e empregado.

Em princípio, jamais um contratante exerceria poder de comando sobre o outro. Pelo contrato, certos recursos são alocados consensualmente.

A experiência moderna, contudo, mostra que, na prática, muitas relações contratuais dependem do poder de um contratante sobre o outro.

Ainda que na seara dos contratos interempresariais, seja porque um contratante é maior do que outro, seja porque o contrato depende de informações que só uma das partes pode produzir, relações de agente-principal são cada vez mais usuais.

Atenha-se, por exemplo, ao contrato de franquia, no qual se verifica indubitável relação de comando da franqueadora para com a franqueada.

${ }^{159}$ F. ARAÚJO, Teoria... cit., p. 215.

${ }^{160}$ F. R. C. PINHEIRO FILHO, Teoria da agência (problema agente-principal), in O que é análise econômica do direito, coords. Maria Clara Pereira Barreto e Vinicius Klein, Belo Horizonte, Fórum, 2011, p. 103 
Conexa à teoria da agência, há, também, especial atenção à assimetria de informações passível de criar risco moral ("moral hazard") ${ }^{161}$. A noção é a de que o principal não possui as mesmas informações do agente, implicando duas consequências negativas. O principal não tem total ciência da atuação do agente, o que pode levá-lo a tomada de decisões equivocadas. Ao mesmo tempo, o agente, ao perceber a assimetria de informações, fica livre para tomar medidas de acordo com sua preferência, à revelia do principal $^{162}$.

Novamente, com o intuito de aclarar conceitos, ressalve-se que o risco moral advém dos problemas decorrentes de eventual falta de comunicação entre aquele que dá a ordem e o que a recebe (respectivamente, principal e agente), ou seja, se as informações sobre a atuação do agente não estão atingindo claramente o principal, este estará correndo o risco de tomar deliberações erradas.

Ainda no tocante ao contrato de franquia, se uma franqueadora não está recebendo as informações sobre o volume de vendas de uma de suas franqueadas, ela estará correndo o risco de tomar uma decisão mercadológica equivocada em região próxima àquela da franqueada.

No mesmo sentido, a franqueada, uma vez percebendo que a "supervisão" da franqueadora não é realizada de forma cuidadosa, tende à tomada de decisões sem o consentimento da franqueadora.

Ante esta conjuntura, surgem os custos de agência. Quando os contratantes se encontrarem em uma situação análoga à de principal/agente no contexto das empresas, podem surgir custos para operacionalização do contrato decorrentes da troca de informações entre os contratantes.

Sendo assim, é forçoso reconhecer a necessidade de monitorar a conduta do agente. São os chamados custos de monitoramento ou supervisão ${ }^{163}$. Além disto, também é

\footnotetext{
${ }^{161}$ F. ARAúJo, Teoria... cit., p. 216. V., também, a respeito, F. ARAúJo, Uma análise... cit., p. 87: "o facto de as partes disporem de informação privativa, não-partilhada, que é relevante para o cumprimento das obrigaçães geradas pelo contrato - dá origem a uma "disfunção oportunista", que consiste essencialmente no facto de uma das partes, ou até ambas reciprocamente, poderem fazer degenerar a prometida conduta de cooperação numa conduta de apropriação de ganhos à custa do interesses e expectativas da contraparte".

${ }^{162}$ F. R. C. PINHEIRO FILHO, Teoria... cit., p. 104.

${ }^{163}$ F. ARAÚJO, Teoria... cit., p. 216.
} 
possível incentivar o agente a atender ao interesse do principal, mormente, quando os custos de monitoramento forem demasiadamente altos. Exemplo clássico é a criação de mecanismos de incentivos meritocráticos impostos pelos acionistas ao administrador ${ }^{164}$. Por fim, há também os custos decorrentes das próprias perdas quando a relação agenteprincipal não atinge a eficiência ótima. Assim, os custos de agência são classificados em três espécies: custos de monitoramento ou supervisão; custos com o incentivo ao agente; e custos decorrentes das perdas residuais ${ }^{165}$.

A teoria de agência, utilizando este modelo, é aplicada a vários campos do direito como, por exemplo, nas relações laborais, regulatórias ou nas políticas públicas e, inclusive, no domínio dos contratos, realidade em que os contratantes são tratados como agente e principal.

Ademais, em sede de comparação, entre a análise dos custos de transação com a teoria da agência, algumas conclusões já podem ser alcançadas. Os métodos podem ser considerados distintos na medida em que na análise dos custos de transação o foco é deslocado completamente para a troca, a externalidade e a relação custo/benefício do contrato. Já pela teoria de agência, ganha relevo a interação entre agente e principal e o custo do atrito causado pela assimetria de informações e modos de incentivo (qual será o custo da franqueadora para supervisionar suas franqueadas?).

Admite-se, entretanto, não haver obstáculos para contabilizar os custos de agência como custos de transação. Daí o caráter antinômico ser simplesmente aparente. A teoria da agência, portanto, guarda relevância na medida em que apresenta, de modo mais detalhado, custos (de transação) ínsitos a certas trocas e empecilhos decorrentes de eventual dificuldade na transmissão de informações.

Feitos estes esclarecimentos, cumpre salientar, a final, que pela teoria dos custos de transação, englobando também os custos de agência, tudo o que onerar os contratantes em decorrência do próprio contrato prejudica o bem-estar ideal.

\footnotetext{
${ }^{164}$ F. R. C. PINHEIRO FilHo, Teoria... cit., p. 108.

${ }^{165}$ F. R. C. PINHEIRO FILHO, Teoria... cit., p. 105.
} 
Esta onerosidade (custo) ocorre em um ambiente imerso numa racionalidade limitada, com informações insuficientes e assimetricamente repartidas. São necessários, portanto, veículos para manutenção da estabilidade negocial com o intuito de reduzir, ao máximo, os custos de transação. Quanto menor os custos de transação, maior será a abertura para eventual renegociação superveniente. Almeja-se, assim, a possibilidade de espaço para confiança na estabilidade, de modo a estimular os investimentos na própria relação. Ao mesmo tempo, há a flexibilidade para lidar com mazelas supervenientes, com a menor onerosidade possível às partes ${ }^{166}$.

Neste contexto, o corolário principal é a salvaguarda do predadorismo oportunista. Assim, ante a insuficiência, ou mesmo, assimetria de informações, a conduta oportunista deve ser coibida, por exemplo, com significativas sanções contratuais. Em outras palavras, é imprescindível a sanção àquele que, imotivadamente, aumente os custos de transação ou impeça sua internalização ${ }^{167}$.

Desse modo, acerca dos contratos incompletos, raciocinando conforme a economia dos custos de transação, podem eles ser admitidos, se necessário, ou seja, desde que colaborem com a redução dos custos de transação.

Seja porque a racionalidade é limitada ou porque as informações são insuficientes e assimétricas, são cada vez mais comuns contratos em que o instrumento escrito não dispõe todos os detalhes do contexto fático presente e muito menos quanto às circunstâncias futuras durante o período em que durar o vínculo contratual.

Não se pode, sem maiores ressalvas, propor a resolução de todo e qualquer litígio contratual na dicotomia entre o risco negocial e o dito "mal contrato".

No mesmo sentido, não se justifica a priori procurar resolver os conflitos com a simples análise sobre a coerência e previsibilidade dos investimentos realizados pela contraparte na crença de que não estavam previstos em contrato ou dele não se podiam ser inferidos.

\footnotetext{
${ }^{166}$ F. ARAÚJo, Teoria... cit., p. 208.

${ }^{167}$ F. ARAÚJO, Teoria... cit., p. 208.
} 
Certamente, segundo as circunstâncias negociais, as partes podem consentir com certa incompletude contratual, muito provavelmente porque os custos de transação para prever aquilo que restará em aberto (para completar o contrato) seriam indesejados ou até impeditivos.

Sendo assim, torna-se oportuna a seguinte explanação sobre a chamada teoria dos contratos incompletos.

\section{c) teoria dos contratos incompletos}

Imersa na análise econômica do direito, em particular, aos contratos, é a chamada teoria do contrato incompleto ${ }^{168}$. A premissa fundamental é empírica ou até intuitiva. Quando dois contratantes aproximam-se com vontade de celebrar um contrato (ainda mais de longa duração), por vezes o ambiente não é adequado (leia-se: a negociação não é simples) ${ }^{169}$.

Pode surgir, assim, incerteza quanto às contingências que potencialmente influenciarão no desejado equilíbrio econômico, ou, diante de tais contingências, sobre qual será o preço justo para a assunção de riscos. Também pode ser difícil definir o que caracterizará o inadimplemento relativo (ainda que nos limites daquilo que se entenda como o standard de conduta simétrico à boa-fé objetiva) ${ }^{170}$.

Como consequência natural destas dificuldades, resta ainda mais complicado estabelecer ex ante sanções contratuais adequadas, podendo culminar com alta litigiosidade entre os contratantes.

Estabilizadas tais ideias, é mister o seguinte questionamento: até que ponto é proveitoso buscar o estabelecimento ex ante de obrigações e sanções de forma alinhada e

${ }^{168}$ F. ARAÚJO, Teoria... cit., p. 147: "Se tivéssemos que escolher as contribuições mais originais e férteis da Análise Económica para a Teoria do Contrato, num lugar cimeiro colocaríamos decerto a intuição da chamada "Incomplete-Contract Theory" sobre as vantagens do "contrato incompleto" e a ponderação dos seus inúmeros corolários, entre eles a colocação do instrumento contratual numa posição intermediária entre, por um lado, o recurso ao mercado e ao seu mecanismo de puros incentivos, e por outro lado o recurso a soluções integradas, com os seus mecanismos de comando e de disposição do risco - associando a opção contratual e, dentro dela, a opção sobre o acabamento do clausulado contratual, a uma espécie de opção implícita entre “incentivo" e "seguro". V., também a respeito, R. SZTAJN, Sociedades e contratos incompletos, in Revista da Faculdade de Direito da USP, v. 101, 2006, p. 171-179.

${ }^{169}$ F. ARAÚJO, Teoria... cit., p. 148.

${ }^{170}$ F. ARAÚJO, Teoria... cit., p. 148. 
adequada às contingências e riscos assumidos em uma situação com vários obstáculos e informações insuficientes?

De tal questão, decorre outra: resta desistir da contratação quando a negociação se localizar para lá dos horizontes do aceitável?

A resposta a ambas as questões é possível a partir da teoria dos contratos incompletos. Em suma, o inacabamento contratual pode ser o veículo mais eficiente e menos custoso em um mundo de imperfeições e incertezas ${ }^{171}$.

Desse modo, nesta atmosfera de insegurança, o indivíduo, intentando firmar uma relação contratual duradoura, terá duas opções: desistir da contratação e, para o bem ou mal, permanecer vulnerável às oscilações de mercado; ou firmar o contrato (confiar no futuro) e ter uma certa noção do que ocorrerá (ou seja, por um período de tempo X, os recursos Y serão alocados da forma Z). Nesta opção, ele evita a incerteza decorrente de possíveis oscilações de mercado, mas, assume riscos, contando com contingências que podem ocorrer em maior ou menor escala. Quanto mais obscuro for o ambiente contratual, maiores serão os custos para regular a forma Z, para alocação dos recursos $\mathrm{Y}$, durante o período $\mathrm{X}^{172}$.

Naturalmente, a escolha dos contratantes tenderá àquela que harmonize melhor uma relação custo/benefício.

Ocorre que um contrato incompleto, em tese, pode, ao mesmo tempo, prover a segurança de futuro desejada, sem custos tão elevados, pois não será previsto exatamente (completamente) o tratamento de X, Y e Z.

Tal relação contratual, portanto, dependerá ainda mais da confiança recíproca entre as partes, pois o vínculo contratual (inicialmente incompleto) deverá ser consensualmente aperfeiçoado concomitante à execução contínua do contrato ${ }^{173}$.

Some-se, ainda, o entendimento exposto por GIUSEPPE CLERICO, que também defende a vantagem da contratação pela via incompleta, mostrando que, potencialmente, a

\footnotetext{
${ }^{171}$ F. ARAÚJO, Teoria... cit., p. 151.

${ }^{172}$ F. ARAÚJO, Teoria... cit., p. 150.

${ }^{173}$ Em igual sentido, v. G. CLERICO, Analisi economica del contratto, Milão, Giuffrè, 2008, p. 33-37.
} 
resolução litigiosa de contratos incompletos implicará maiores dificuldades ao juiz, uma vez que não se poderá aferir eventual inadimplemento com base nas disposições consensuais estabelecidas pelas partes.

Nesse contexto, GIUSEPPE CleRICO invoca o denominado "princípio de não retratação". Se, no passado, as partes dispuseram de suas liberdades e estabeleceram obrigações futuras, o simples fato de o conteúdo de tais obrigações estar incompleto, não deve acarretar impossibilidade de execução do contrato.

Pelo contrário, o intérprete deve aferir como tal obrigação atenderia da melhor forma ao interesse da parte adimplente, não podendo a parte inadimplente proceder à retratação apoiando-se no fato de que a contraparte nada pode fazer, pois jamais houve consentimento completo sobre a obrigação ${ }^{174}$.

Desta forma, GIUSEPPE ClERICO conclui que o contrato incompleto pode ser compreendido como uma sucessão de obrigações contratuais cuja execução depende do interesse da parte credora da obrigação ${ }^{175}$. Tal raciocínio resta lógico na medida em que os contratantes auferiram vantagens quando da celebração pela via incompleta (dispensaram ulteriores custos de transação). Nada mais justo do que, em caso de execução forçada do contrato, definir o conteúdo obrigacional da forma que melhor atender ao interesse do credor, guardadas as circunstâncias negociais.

O contrato incompleto, destarte, não deve ser compreendido como vínculo pela qual são dispostas opções futuras que podem ou não ser exercidas pelas partes. A obrigação é tão exequível como qualquer outra. Apenas seu conteúdo será preenchido em momento futuro.

Ainda, no mesmo contexto de negócios voluntariamente incompletos, descortinam-se os chamados contratos-quadro ${ }^{176}$, muito utilizados em relações comerciais em que as empresas contratantes desejam estabelecer os parâmetros de uma série de futuras relações contratuais. A incompletude do vínculo, muitas vezes, serve para evitar custos desnecessários ex ante com a negociação das cláusulas contratuais.

\footnotetext{
${ }^{174}$ Analisi... cit., p. 37.

${ }^{175}$ Analisi... cit., p. 37.

${ }^{176}$ V., por todos, para uma visão completa, J. GATSI, Le contrat-cadre, Paris, L.G.D.J., 1996.
} 
O contrato-quadro prevê, usualmente, a celebração de novos negócios, ou seja, há, em regra, uma relação contratual de duração. CRISTIANO ZANETTI aduz que, caso não sejam celebrados os ulteriores negócios, ou partes deles, a execução específica é de difícil ou impossível assimilação ${ }^{177}$, eis que as obrigações não estariam dispostas (raciocínio: "moldura sem quadro").

Em princípio, poder-se-ia dizer que CRISTIANo ZANETTI e GIUSEPPE CleRICO apresentam posições divergentes, na medida em que este defende a exequibilidade da contratação incompleta pelo dito "princípio de não retratação". Logo, o juiz poderia "completar" o conteúdo contratual para proceder à execução forçada da obrigação.

Em vista do acima relatado, recorre-se, por analogia, à classificação gradual da preliminaridade, conforme o alvitre de ALCIDES TOMASETTI JR., autor que propôs a divisão do contrato preliminar em distintas classes de completude: preliminaridade mínima, média e máxima. No nível máximo, os elementos essenciais da obrigação encontrar-se-iam presentes de modo a afastar maiores dificuldades no tocante à execução forçada. Gradativamente, o contrato preliminar pode ter sido firmado com menores níveis de plenitude a ponto de dificultar sobremaneira a execução do contrato ${ }^{178}$.

Destarte, não se deve a priori concluir pela inexequibilidade das obrigações constantes em relações cujo conteúdo foi aposto voluntariamente de forma incompleta. É preciso, antes, permitir ao intérprete seja a circunstância do caso concreto apreciada para verificar o "nível de completude" das obrigações firmadas e, se possível, impor eventual tutela substitutiva da vontade a fim de forçar o cumprimento da obrigação contratada pela via incompleta ${ }^{179}$.

Já sob outro aspecto, em que pese a inequívoca relação do chamado contratoquadro com a incompletude contratual, não se está afirmando, de modo algum, que são sinônimos contratos incompletos e contratos-quadro. O contrato incompleto, ou a

${ }^{177}$ Responsabilidade pela ruptura das negociações, São Paulo, Juarez de Oliveira, 2005, p. 22.

${ }^{178}$ V., a respeito, A execução do contrato preliminar, (tese-USP), São Paulo, 1982, p. 22-24.

${ }^{179}$ V., em sentido similar, W. FERNANDES E J. M. OLIVEIRA, Contrato preliminar: segurança de contratar, in Fundamentos e princípios dos contratos empresariais, coord. Wanderley Fernandes, São Paulo, SaraivaFGV, 2007, p. 316: "Atento à função econômico-social do contrato preliminar de trazer segurança às partes durante o processo de formação do contrato, o ordenamento jurídico oferece às partes mecanismos para fazê-lo produzir os efeitos pretendidos, mesmo com o inadimplemento da outra parte. Além da indenização pelas e danos, a legislação prevê uma tutela específica, mediante a qual o credor pode obter uma sentença que substitua os efeitos da declaração de vontade do obrigado, constituindo-se o contrato definitivo". 
incompletude contratual, é o gênero no qual a figura do contrato-quadro se insere. Ademais, em situações complexas quando é muito custoso ou impossível prever todas as possíveis nuances futuras, o contrato-quadro pode delimitar certas disposições mútuas. Não é, entretanto, a única ferramenta a ser utilizada pelas partes, como será adiante observado.

O contrato-quadro é uma figura relativamente nova. Sua origem ocorreu em França, num julgado de 1966 da Cour d'Appel, quando a expressão foi pela primeira vez utilizada. $^{180}$.

Pois bem, por meio de um acordo inicial, que determina não só diretrizes da negociação, mas ainda disposições contratuais que já podem ser (seguramente) convencionadas, os contratantes também decidem, na medida do possível, como se desenrolará a relação contratual e o que deverá ser objeto de futura negociação para "completar" o contrato. Em França, os contratos derivados do contrato-quadro são chamados contratos de aplicação (contrats d'application).

A esse respeito, é ainda possível uma ulterior observação: no meio empresarial, comumente, são celebrados acordos preliminares. Os denominados protocolos de intenção ou, em inglês, memorandun of understandings, famoso pela sigla "MOU". É imperioso esclarecer que a priori não há como estabelecer a natureza jurídica de tais pactos. Por exemplo, se um protocolo de intenções simplesmente estabelece que as partes concordam em realizar uma compra e venda de ações, tal contrato nada mais é do que um contrato preliminar; só será adimplido com nova declaração de vontade negocial.

Por outro lado, caso este pacto determine que um fornecedor entregará certa mercadoria exclusivamente para uma rede de empresas, o aludido protocolo de intenções de preliminar, nada tem. É um contrato definitivo, pronto e incompleto, pois as partes assim decidiram. Será necessária, contudo, a celebração de novos contratos para determinar, por exemplo, qual o preço da mercadoria, o lugar de entrega. Enfim, aquilo que por qualquer motivo não tenha sido previamente acordado. Neste cenário, está-se diante da figura do contrato-quadro.

${ }^{180}$ Segundo noticia J. GATSI, Le contrat-cadre..., p. 4. 
Ao contrário do contrato preliminar, que já deve preencher todos os requisitos de validade do contrato definitivo, mormente a teor do art. 462 do Código Civil, o contrato-quadro “caracteriza-se justamente por não possuir todos esses requisitos" ${ }^{181}$.

Há, ademais, outra figura similar no direito continental-europeu sobre instituto que parece ser semelhante, todavia sob a denominação de negócio jurídico per relationem $^{182}$.

JUNQUEIRA DE AZEVEDO ${ }^{183}$ é taxativo ao afirmar que a figura do negócio jurídico per relationem não recebe a devida atenção da doutrina e jurisprudência atuais, mas anota que já em 1974 ele teve oportunidade de examinar o tema:

"Evidentemente, faz parte do objeto, e é também conteúdo expresso, tudo aquilo que, por remissão, se incluiu no negócio jurídico. Tem-se, então, o chamado negócio jurídico per relationem, isto é, aqueles negócios nos quais uma parte do seu conteúdo ou já consta de outros atos ou negócios, havendo no negócio jurídico per relationem somente uma

${ }^{181}$ C. S. ZANETTI, Responsabilidade... cit., p. 21.

${ }^{182}$ Cf. E. BETTI, Negozio giuridico, in Novissimo Digesto Italiano, v. 11, UTET, p. 213: “Configura un nesso di sequenzia la continuità fra due o più negozi, che, serbando ciascuno la propria fisionomia, si succedono l'un all'altro in ordine al medesimo scopo, siccome indefettibile premessa e coerente conseguenza. Na sequenza organizzata offre um esempio di fattispecie com formazione successiva, che in senso ampio si qualifica procedimento, e consiste in più atti giurici successivi diretti alla medesima finalità, dei quali ognuno pressuppone il precedente, e preannuncia il susseguente, in ordine progressivo. (...) $\grave{E}$ questa la figura che, insieme com altre esteriormente affini, va sotto il nome ambíguo e poco appariscente di negozio per relationem.", Em tradução livre: "Configura um nexo de sequência a continuidade entre dois ou mais negócios, que, preservando cada um seu caráter, sucedem-se em ordem para o mesmo fim, como premissa infalivel e resultado coerente. Na sequência organizada há um exemplo de fattispecie com formação sucessiva, que, em um sentido amplo, qualifica-se como um procedimento, e é composto por vários atos jurídicos subsequentes direcionados para o mesmo fim, de que cada um pressupõe o precedente, e anuncia o seguinte em ordem progressiva. (...) Esta é a figura que, junto com outra externamente semelhante, é chamada pelo nome ambíguo e pouco aparente per relationem"; e também, como observa A. JUNQUEIRA DE AZEVEDO, a monografia específica datada de 1982 na Espanha de M. D. DíAZ-AMBronA BARDAJI, El negocio jurídico per relationem en el Codigo Civil, 2a ed., Madrid, UNED, 1994.

${ }^{183}$ Contrato de distribuição por prazo determinado com cláusula de exclusividade recíproca. Configuração de negócio jurídico per relationem na cláusula de opção de compra dos direitos do distribuidor pela fabricante e conseqüente restrição da respectiva eficácia. Exercício abusivo do direito de compra, equivalente a resilição unilateral, sem a utilização do procedimento pactuado, com violação da boa-fé objetiva, in Novos estudos... cit., p. 287-310. 
remissão que a integra ao seu conteúdo sem repeti-la, ou será ainda determinada por outros atos ou negócios a serem realizados" 184

Quanto aos "negócios nos quais uma parte do seu conteúdo já consta de outros atos ou negócio”, denominam-se negócios formalmente per relationem, adverte o autor que podem ser considerados falsos negócios per relationem. Já os negócios em que uma parte de seu conteúdo "será ainda determinada por outros atos ou negócios a serem realizados" podem ser considerados negócios substancialmente per relationem.

Estes são exemplos aptos a enfatizar as benesses de um sistema que admite a incompletude contratual.

Interessante é notar que, com certas características, teorias contratuais não relacionadas com a análise econômica também desenvolveram figuras semelhantes, como o "contrato-quadro" e o "negócio jurídico per relationem”.

Verificada a existência de contratos incompletos, a abusividade da resilição pode ser compreendida de modo distinto. A incompletude contratual não deve permitir condutas oportunistas, ou seja, não se pode prestigiar o direito de resilição unilateral de certo contratante simplesmente porque o programa contratual não está totalmente previsto. Se restar comprovada que a ausência de previsões contratuais foi desejada ou, ao menos, suportada pelas partes contratantes, a denúncia contratual abusiva, ainda assim, só deve produzir efeitos depois de período razoável.

\section{Seção III - Abordagem relacional do contrato}

A teoria relacional do contrato é atribuída a IAN RODERICK MACNEIL, professor da Northwestern University School of Law. Seus estudos sobre o relational contract

${ }^{184}$ A. JUNQUEIRA DE AZEVEDO, Negócio jurídico - existência, validade e eficácia, $4^{\mathrm{a}}$ ed., São Paulo Saraiva, 2002, p. 137 (excerto não modificado desde a primeira edição (1974) segundo informações do próprio autor em Contrato de distribuição por prazo... cit., p. 299). 
remontam a meados da década de 60, sendo paulatinamente aprofundados por meio de diversos artigos ${ }^{185}$ publicados durante duas décadas, além de outros mais recentes.

Numa breve definição, o contrato relacional é caracterizado por uma relação contratual complexa em que os contratantes não reduzem a termo, porque não podem ou não querem, os pontos fulcrais de todas ou de certas obrigações. O contrato relacional é uma figura ideal que se opõe ao contrato descontínuo ou pontual (discrete contract). A característica relacional é frequentemente observada em relações de trato sucessivo, mas, excepcionalmente até em pactos instantâneos, há espaço para a perspectiva relacional ${ }^{186}$.

Reputa-se necessário o estudo da abordagem relacional dos contratos, embasado pelos estudos de IAN MACNEIL, além de outros teóricos sobre o assunto, dentre os quais, alguns doutrinadores pátrios. ${ }^{187}$.

É imprescindível o realce ao declarado escopo da teoria no sentido de perseguir maior praticidade e dinamismo ao direito contratual. Para tanto, é preciso organizar todos os elementos formadores desta abordagem. Saliente-se que, a exemplo de outros trabalhos, a pesquisa a seguir exposta não se restringe à obra de IAN MACNEIL, mas sim se circunscreve aos principais estudiosos e até mesmo de alguns outros autores que antecederam IAN MACNEIL, trazendo ideias embrionárias a respeito desta teoria inovadora.

Nas lições de IAN MACNEIL verifica-se, dentre as raízes primárias do contrato, a especialização do trabalho (primeira raiz do contrato), acompanhada à ideia de intercâmbio ou troca (segunda raiz do contrato). O contrato, portanto, identifica-se como figura intrínseca à sociedade desde que esta seja suficientemente complexa de modo a necessitar especificação do trabalho.

185 Os principais estudos e, consequentemente, os mais citados do autor, foram intitulados Many Futures of Contracts, in Southern California Law Review, v. 47, n. 3, 1974, p. 691-816 e Contracts: Adjustment of Long-Term Economic Relations under Classical, Neoclassical, and Relational Contract Law, in Northwestern University Law Review, v. 72, n. 6, 1978, p. 854-905. Há também uma obra publicada na qual a teoria é amplamente apresentada: The New Social Contract: An Inquiry Into Modern Contractual Relations, New Haven, Yale University, 1980, costumeiramente lembrada em estudos modernos. Recentemente foi publicada tradução para o português: $O$ novo contrato social, trad. port. Alvamar de Campos Andrade Lamparelli, Rio de Janeiro, Elsevier, 2009.

${ }^{186}$ Contratos relacionais... cit.

${ }^{187}$ V., dentre outros, R. P. MACEDO JR., Contratos relacionais... cit.; e R. P. CAMILO JR., O contrato de distribuição: uma análise à luz da teoria relacional (tese-USP), São Paulo, 2004, principalmente, p. 97-127 e 256-259. 
A terceira raiz do contrato consiste na escolha num contexto de liberdade para decidir sobre uma série de condutas à disposição.

Todavia, numa sociedade com especialização do trabalho e troca, associados à possibilidade de escolha, ainda não é possível o surgimento do contrato, mas só quando percebida, a quarta raiz: percepção consciente do futuro (awareness of future).

Estas são as quatro raízes formadoras dos contratos ${ }^{188}$. Em sua concepção, aduz IAN MACNEIL que o contrato nada mais é do que o planejamento futuro de suas três primeiras raízes primárias. $\mathrm{Na}$ verdade, as relações entre indivíduos ao projetar (daí a quarta raiz) como se dará em um futuro próximo a especialização do trabalho, a troca e a escolha.

Assim, pela teoria relacional, é necessário compreender que toda e qualquer promessa inserida no contrato é formada pelos chamados elementos promissórios e, também, por elementos não-promissórios.

A promessa de um devedor pode ser definida pela comunicação no presente de um compromisso no futuro a uma troca, específica, recíproca e mensurável ${ }^{189}$. Certamente, a promessa é o modo mais fácil de gerar a expectativa compatível com o interesse objetivo do credor na satisfação de seu crédito.

Em regra, no entanto, a expectativa da contraparte não é exclusivamente formada pelo conteúdo da promessa. As características do promitente são elementos nãopromissórios que também complementam a formação da expectativa. Dentre as principais, comandos, status, papel social, parentesco, hábitos, padrões burocráticos, etc. Outros fatores não-promissórios, ainda, podem ser reputados até mais latentes, a exemplo das próprias trocas no presente passíveis de gerar a expectativa de trocas futuras ${ }^{190}$, ou seja, a ocorrência de vínculo contratual contínuo em andamento gera a expectativa de preservação da relação.

\footnotetext{
${ }^{188}$ I. MACNEIL, The New... cit., p. 4-5.

${ }^{189}$ I. MACNEIL, The Many... cit., p. 715.

${ }^{190}$ Cf. I. MACNEIL, The Many... cit., p. 715-716. V., também a respeito, R. P. MACEdo JR., Contratos relacionais... cit., p. 126.
} 
É forçoso observar, ademais, o caráter eminentemente empírico de toda a teoria relacional na medida em que o resultado (e.g. a preservação do vínculo contratual) em nada inova na seara contratual. Ocorre que a abordagem relacional, embasada por uma série de elementos revelados (e não criados) nas relações contratuais, visa a resultados práticos além daqueles obtidos sob a égide do paradigma hoje dominante, levando-se em conta, outrossim, as finalidades precípuas da análise econômica ${ }^{191}$.

PAULO ARAÚJo indaga se a abordagem relacional realmente se apresenta como novidade "aos olhos dos leitores mais atentos às contemporâneas teorias interpretativas dos contratos ${ }^{\prime \prime 192}$, considerando-se as cláusulas gerais insertas nos arts. 421 e 422 do Código Civil.

Ao estudar os contratos de longa duração, o referido autor concorda, entretanto, que a proposta de IAN MACNEIL é relevante uma vez que traz para a discussão a realidade empírica, fundadas em perspectivas do common law $^{193}$.

No mesmo sentido, por vezes, no sistema do common law, a teoria relacional tem sido endereçada como a outra face de um direito contratual dominado por disposições contratuais escritas ${ }^{194}$.

\footnotetext{
${ }^{191}$ Neste contexto, já deve ficar claro que o contrato relacional não é uma categoria autônoma de contrato (v., a respeito, P. VInCENT-Jones, The Reception of Ian Macneil's Work on Contract in the U.K., in The Relational Theory of Contract: Selected Works of Ian Macneil, Londres, Sweet \& Maxwell, 2001, p. 72 e, também, M. MEKKI, L'intérêt général et le contrat - contribution à une étude de le hierárchie des intérêts en droit privé, Paris, L.G.D.J., 2004, p. 731-734.

${ }^{192}$ P. D. R. de ARAúJo, Prorrogação... cit., p. 98.

${ }^{193}$ P. D. R. de ARAúJO, Prorrogação...cit., p. 99.

${ }^{194}$ V., a respeito, L. Mulcahy e J. Tilotson, Contract Law in Perspective, $4^{\mathrm{a}}$ ed., Londres, Cavendish, 2004, p. 51. Tanto é assim que em um estudo de casos empíricos sobre a boa-fé nos países europeus, dois importantes estudiosos - REINHARD ZIMMERMANN e SIMON WhITTAKER - apresentaram pesquisa, cujo trabalho foi o resultado de manifestações de uma séria de juristas de vários países sobre inúmeros casos concretos. Em dois deles, o litígio hipotético dizia respeito à resilição unilateral abusiva (ou não) do contrato. $\mathrm{Na}$ Inglaterra, a resposta foi categórica no sentido de não ser reconhecida a figura do "relational contract": "English law does not recognize any special concept of a 'long-term contract' or 'relational contract' and instead leaves it to the parties to make their own appropriate provision, in particular for any changes which may be needed owing to circumstances changing over time. (...) Rodney may not claim damages as no breach of contract has been commited by Oliver; nor is there any tortious ground of recovery on these facts" (Good Faith in European Law, Cambridge, Cambridge University Press, 2004, p. 539). Em tradução livre: “A Lei inglesa não reconhece qualquer conceito especial de 'contrato de longa duração' ou 'contrato relacional' e, ao invés disso, permite às partes sejam feitas as próprias provisões, em particular acerca de quaisquer mudanças que possam ser necessárias devido à alteração das circunstâncias no tempo. (...) Rodney não pode pleitear indenização porque não houve violação do contrato por Oliver, tampouco há qualquer grau de ilicitude”.
} 
O exame relacional, quando da alteração das circunstâncias, permite a chamada "realocação eficiente de recursos"195 não somente em momento anterior à celebração do contrato, mas também quando alterações são necessárias.

Pela "realocação eficiente de recursos" é preferível alterar a relação contratual para permitir sua continuidade ao invés de determinar a sua extinção, ou seja, os custos de transação são mais facilmente amortizados se a relação contratual for mantida do que se for extinta.

Para realizar esta realocação de recursos é necessária a percepção de que o contrato não pode ser encarado simplesmente como relação econômica visando ao lucro dos participantes. É preciso levar em conta o contexto social no qual as trocas estão sendo realizadas. Ocorre que tal cotejo só pode ocorrer quando valoradas as promessas, expectativas, ponderações e custos de toda a transação ou transações envolvidas ${ }^{196}$.

O contrato relacional se opõe ao que é denominado "contrato descontínuo". Como ensina MACEDO JR., tanto os contratos relacionais quanto os descontínuos dispõem sobre o que ainda vai acontecer. O fator determinante é a relevância deste "planejamento", uma vez que o plano das trocas a serem realizadas em contratos descontínuos é subsidiário ao aspecto principal na transação, ao passo que, em um contrato relacional, a maior flexibilidade das disposições é inerente à própria relação ${ }^{197}$, seja pela natureza do vínculo ou por genuíno interesse das partes, advindos de variados aspectos, os quais serão amplamente estudados.

\footnotetext{
${ }^{195}$ P. D. R. de ARAúuo, Prorrogação...cit., p. 100.

${ }^{196}$ P. D. R. de ARAúJo, Prorrogação ... cit., p. 100.

${ }^{197}$ R. P. MACEDO JR., Contratos relacionais... cit., p. 133.
} 
Deste modo, a distinção está na essencialidade da preservação do vínculo. A continuidade pode ser elemento essencial deste ou daquele negócio jurídico ${ }^{198}$.

Consoante lição de FERNANDO ARAÚJO ${ }^{199}$, a teoria relacional, ao invés de se afastar de elaborações doutrinárias e jurisprudenciais anteriores, contribui para o realismo da análise, estipulando regras pragmáticas sem maiores filtros dogmáticos.

O contrato relacional converge ao senso comum de que se houver mudança nas circunstâncias fáticas, o sistema repudiará a alteração, nem que para isso seja necessária a extinção do vínculo. A noção é exatamente contrária. O contrato tende à transformação. A alteração das circunstâncias fáticas não é excepcional, mas regra. A sociedade pósmoderna espera que o contratante saiba lidar com as modificações.

Nas palavras de PAULA CESARINO: “A principal diferença entre os contratos relacionais e os não relacionais é que aqueles partem da premissa segundo a qual a relação contratual deve responder a eventuais mudanças de circunstâncias, para que possam subsistir e não ser rescindidos, enquanto os não relacionais dão primazia à rescisão, ${ }^{, 200}$.

PAULA FORGIONI ${ }^{201}$, a seu turno, resumiu as finalidades propostas por IAN MACNEIL na seguinte síntese: $i$ ) tendência a se estender no tempo; $i$ ) o contrato não só visa às regras atinentes as trocas mas disciplina o relacionamento a ser fruído ao "longo da vida

${ }^{198}$ The New... cit., p. 66: "The next relational norm, preservation of the relation, is na intensification and expansion of the norm of contractual solidarity. Discrete transactions self-destruct rapidly by reason of performance, and are expected to be replaced by other discrete transactions. But the ongoing character of relations is such that preservation of the relation becomes a norm. This norm is contingent, in the sense that it ceases to operate whenever the prevailing forces in and on a relation lead to a termination. Sometimes this comes about because the relation was expected to have a finite life from the start, (...). But often contractual relations are expected to continue indefinitely, and in fact do.". Na tradução de Alvamar de Campos Andrade Lamparelli, Rio de Janeiro, Elsevier, 2009, p. 64: “A próxima norma relacional, a preservação da relação, constitui uma intensificação e expansão da norma de solidariedade contratual. Negociações descontínuas se autodestroem rapidamente em virtude do cumprimento (performance), e se espera que sejam substituídas por outras negociações descontínuas. Porém, o caráter contínuo das relações é tal que a preservação da relação se torna uma norma. Esta norma é contingente, no sentido de que cessa de operar sempre que as forças prevalecentes, em uma relação ou sobre esta, levam ao término. Algumas vezes isso ocorre porque desde o início se esperava que a relação tivesse uma vida finita; (...). Mas geralmente se espera que as relações contratuais continuem indefinitivamente, e na verdade o fazem”.

${ }^{199}$ F. ARAÚJO, Teoria... cit., p. 394.

${ }^{200}$ Contratos relacionais, (Dissertação-Milton Campos), disponível em http://www.mcampos.br/posgraduacao/mestrado/dissertacoes/. - acesso em 17 de outubro de 2011.

${ }^{201}$ Contrato... cit., p. 71. 
do contrato". Sendo assim, é comum que sejam formulados termos amplos, sem significado claramente definido. Enfim, dada a natureza do negócio jurídico, são lançadas as bases para um comportamento calcado na cooperação entre as partes, ao passo que a ordem específica de obrigações determinadas fica em segundo plano; e iii) há uma interdependência entre as partes, pois o sucesso reverte em benefício da outra.

À evidência, a resolução de novo conflito pressupõe certa autodisciplina de parte a parte visando a assegurar compatibilização eficiente. Por falta de previsão, a contingência é solucionada de modo subjetivo. Não há espaço para desconfiança ${ }^{202}$.

Exatamente nesse contexto de autodisciplina dos contratantes, MACEDO JR. explica que do paradigma relacional nasce um caráter normativo e prescritivo, no qual há necessidade de uma revalorização e ampliação do uso do princípio da boa-fé, justiça e equilíbrio contratual orientando as partes na "direção do reconhecimento das circunstâncias fáticas concretas ${ }^{203}$.

No contrato relacional, presume-se que as partes estão reféns umas das outras, tanto para buscar alternativas àquela relação quanto para o próprio sucesso da transação, já que se a manutenção do contrato "hoje" provavelmente implicará vantagem para ambos os contratantes. Já no tocante aos contratos pontuais ou discretos, há uma disponibilidade de outros parceiros e uma inerente fungibilidade de partes. A manutenção do vínculo "hoje" não guarda qualquer relação com as consequências futuras ${ }^{204}$.

A solução relacional procura o estabelecimento de uma base estável (estrutura de governo), de modo a não descaracterizar a seriedade do vínculo, embora mantida certa flexibilidade para que, diante de inevitáveis percalços de futuras contingências ${ }^{205}$, exista espaço para realocação de recursos.

\footnotetext{
${ }^{202}$ F. ARAÚJO, Teoria... cit., p. 395.

${ }^{203}$ Contratos... cit., p. 286. V., em sentido semelhante, A. JUNQUEIRA DE AZEVEDO, Natureza jurídica do contrato de consórcio (sinalagma indireto). Onerosidade excessiva em contrato de consórcio. Resolução parcial do contrato, in Novos estudos... cit.

${ }^{204}$ F. ARAúJO, Teoria... cit., p. 398.

205 Nesta perspectiva, cf. F. ARAúJO, Teoria... cit., p. 398: "o contrato relacional deixa de estar necessariamente associado a problemas de longa duração, podendo sustentar-se tanto que pode haver problemas de curto prazo como que pode haver contratos de longa duração que não manifestam características relacionais".
} 
Abstraindo-se de critérios subjetivos, existem formas possíveis de operacionalização da estrutura de governo, alicerce dos contratos relacionais. FERNANDO ARAÚJO $^{206}$ disserta sobre os possíveis mecanismos de autointegração e autodisciplina dos contratos. Em sua classificação, podem existir mecanismos externos ou internos. Aqueles podem ser a previsão ex ante de normas supletivas de integração, ou a alternativas ex post como a arbitragem

Já os internos, são alcançados por meio de soluções de reciprocidade e solidariedade entre as partes, ou a uma declarada autoridade assimétrica de uma parte sobre o desenvolvimento da relação, decorrente de um desequilíbrio fático. Tal autoridade, "um híbrido equidistante do mercado e da hierarquia"207, visa à função agregadora de modo a não haver necessidade a recursos externos:

"Postas as coisas nestes termos, compreende-se que a própria formalização dos contratos possa ser reapreciada de um ponto de vista relacional, dando aquela formalização, já não como um modo de "escudar" as posições das partes preparando-as para o embate da adjudicação perante instâncias externas, mas antes como um mecanismo que visa:

- facilitar revisões periódicas do inicialmente estipulado, definindo legitimidades e procedimentos;

- facilitar a integração de lacunas, obviando ao esquecimento ou distorção do que já tenha sido adquirido em formalizações anteriores;

- fornecer um guia explícito para a conduta das partes, explicitando critérios de avaliação que servem tanto para a reciprocidade das partes como serviriam de base para a adjudicação por uma instância externa." 208

\footnotetext{
${ }^{206}$ Teoria... cit., p. 400.

${ }^{207}$ F. ARAÚJO, Teoria... cit., p. 401.

${ }^{208}$ F. ARAÚJO, Teoria... cit., p. 401.
} 
IAN MACNEIL ${ }^{209}$, sobre esta estrutura de governo, ministra que, em um sistema permeado por contratos descontínuos e suas normas correspondentes ao paradigma anterior (clássico), só seria possível encontrar uma desejada flexibilidade afora as transações, jamais por previsões contratuais. Como mencionado na introdução, no momento histórico de ápice da liberdade contratual, houve excessivo afastamento da intervenção estatal no domínio dos contratos. Logo, a flexibilidade nas disposições contratuais era contrária à lógica do paradigma. $\mathrm{O}$ juiz avaliava tão somente a violação à estipulação acordada.

Ainda segundo os ensinamentos de IAN MACNEIL, já pelo paradigma neoclássico, misturavam-se disposições descontínuas e relacionais. Já eram observadas relações mais complexas e duradouras, as quais, todavia, ainda eram enrijecidas por disposições descontínuas que impediam o aperfeiçoamento do planejamento consciente de futuro. Assim, tornava-se possível a inclusão de uma maior flexibilidade contratual, inclusive com a concessão de lacunas para serem preenchidas futuramente.

Ocorre que com a irrefreável e contínua complexidade dos contratos, a despeito das técnicas já mais aprimoradas, naturalmente percebeu-se que o empenho para manter os efeitos do contrato regulados pelo consentimento restava imensamente difícil, além de pouco útil. Ao sistema, portanto, passam a ser incorporados diferentes modos de procedimentos para uma perene administração das trocas, restando as previsões descontínuas e o planejamento meros fatores do processo e não a premissa teórica. Em caso de eventuais alterações da substância da relação contratual, o que acontecerá com o contrato deixa der ser relevante ante o que poderá ser alcançado (em benefício das partes) pelo procedimento perene de administração previamente acordado. Aí certamente devem ser incluídas estruturas de resolução de problemas internos e externos.

Neste ponto, a relação contratual pode ser observada como uma "minissociedade" com uma variedade de disposições que alcançam muito mais do que simplesmente as previsões atinentes às trocas.

Para o sucesso desta "minissociedade", é de suma relevância aquilo que IAN MACNEIL denominou como solidariedade orgânica. A premissa é a de que o indivíduo está cheio de pretensões pessoais e enxerga qualquer outra pessoa como obstáculo à realização de seu objetivo ou como possível ajuda para atingir o resultado pretendido. Bem é verdade

${ }^{209}$ Contracts: Adjustment... cit., p. 900-901. 
que tanto o direito quanto a economia não evoluem unicamente segundo esta máxima hobbesiana. É forçoso reconhecer, contudo, que, realmente, os interesses individuais serão sempre perseguidos.

Nas transações comerciais, pela perspectiva clássica, os membros de uma comunidade uniam-se entre si, pelo contrato, para atingir certo objetivo. As obrigações seriam tão somente aquelas previamente acordadas no pacto ${ }^{210}$. O objetivo, portanto, adviria exclusivamente do prévio acordo de obrigações com a natural alocação de riscos ou, ao menos, de sua decorrência.

Já na abordagem relacional, mais do que um acordo obrigacional seguido de alocação de riscos, o contrato é uma promessa de cooperação para perseguir os objetivos de cada contratante. Qualquer mudança na base do negócio é esperada e deve ser lidada conjuntamente pelos contratantes. Quando necessário, espera-se que o contratante faça concessões para auxílio do outro, antes de exercer seu direito subjetivo pessoal. Ainda, se o fortuito ocasionar perda para ambos, é esperado o equilíbrio das perdas por meios equitativos.

Finalmente, caso após um reequilíbrio das bases do negócio, um contratante tome conduta contrária ao standard esperado, nesta ocasião, é perfeitamente possível a recusa do outro contratante em realizar concessões ${ }^{211}$.

Enfim, para sintetizar a relevância da solidariedade na abordagem relacional, retoma-se a um recorrente e conhecido tema das ciências sociais.

Certos acordos e instituições funcionam como verdadeiras condições para o sucesso das economias capitalistas. Quanto a isto, não existem maiores indagações. A grande diferença da perspectiva relacional é a de que o implemento destas condições não

${ }^{210}$ Com a ressalva de que isto não passa de uma caricatura do contrato como encarado até o século XIX. Segundo R. W. GORDON: "Novamente, essa é uma caricatura mesmo do sistema de regras do século XIX. Ela não considera em sua totalidade o âmbito, muito extenso, das relações fiduciárias juridicamente reconhecidas e executadas, bem como as várias ocasiões em que as cortes paternalisticamente protegeram de maus negócios partes tidas como fracas. A caricatura também ignora aquilo que os juristas vitorianos tinham por garantido como o pano de fundo perante o qual eles legislavam: um conjunto poderoso de códigos e sanções sociais, não-jurídicas" (Macaulay, Macneil and the Discovery of Solidarity and Power in Contract Law, in Wisconsin Law Review, 1985 (565), ora in Revista Direito GV, v. 3, n. 1, trad. port. Marcos de Campos Ludwig e José Rodrigo Rodriguez, São Paulo, jan-jun/2007, p. 201).

${ }^{211}$ R. W. GORDON, Macaulay... cit., p. 569. 
está suficientemente seguro pela exclusiva exequibilidade forçada dos contratos, na medida em que não é induzida (ou tutelada) a cooperação social em larga escala. É imperativo a realização de outro fatores para garantir (de forma segura) as fundações da confiança e cooperação de que o sistema depende. Aí está uma das bases da abordagem relacional. Na definição de IAN MACNEIL, a exemplo de DURKHEIM, a solidariedade orgânica e mecânica $^{212}$.

Destas considerações, infere-se que inserto na cultura do common law, o novo paradigma contratual também aponta para a intervenção estatal no domínio dos contratos de modo a prestigiar os ditos elementos não-promissórios do contrato, quais sejam aqueles componentes aferidos com base no contexto fático da declaração negocial.

Assim sendo, como se verá na parte final deste estudo, as perspectivas ínsitas aos contratos de longa duração e sua perenidade no tempo encontram evidente paralelo também na cultura do common law.

${ }^{212}$ R. W. Gordon, Macaulay, ... cit., p. 570. 


\section{CONSIDERAÇÕES CONCLUSIVAS DA PARTE II: A NOÇÃO DE RESILIÇÃO UNILATERAL ABUSIVA EM CONTRATOS DE LONGA DURAÇÃO}

De todas as premissas estabelecidas nesta segunda parte do trabalho, é possível traçar-se uma síntese da noção de denúncia unilateral abusiva.

Para que seja caracterizado o abuso de direito, certamente é preciso diagnosticar se a conduta do denunciante excede os fins econômico e sociais, limitados por um standard de conduta resultante da boa-fé objetiva.

Para identificação da abusividade, o intérprete pode analisar se a relação contratual evolui de maneira cíclica. Possivelmente, a prorrogação compulsória deve atender à completude do ciclo vigente. Daí a importância das reflexões sobre a moderna influência do aspecto temporal nas relações contratuais duradouras e a atenção às distinções entre os contratos de trato sucessivo (cujas prestações são repetidas várias vezes) e os de execução continuada (cuja prestação dura certo período de tempo).

É neste contexto que as novas teorias contratuais colaboram, ademais, com o maior pragmatismo da dogmática moderna, pelo escopo de fornecer aparato científico para auxiliar a identificação de casos de abuso de direito.

Seria consideravelmente superficial a exposição das premissas sem a proposição de critérios mais sólidos, sob pena de imergir em um indesejado subjetivismo. Não se pode conceber um sistema em que cabe ao intérprete decidir se prorroga ou não a relação contratual simplesmente porque a conduta de uma das partes restou contrária a certo padrão delineado pela boa-fé objetiva. Isto até pode ocorrer, mas, dada a complexidade da sociedade contemporânea, requer-se uma maior atenção a outros critérios reveladores da noção de abusividade.

Exatamente neste momento, o intérprete deverá analisar, por exemplo, se o contrato era completo ou não; se era incompleto, se podia não sê-lo; se a renovação expressa do contrato deveria ter sido realizada; se os custos de transação foram ou não eficientemente absorvidos; se estes custos eram ou deveriam ser conhecidos por ambas as partes. 
Do mesmo modo, também à sua disposição, as ideias forjadas pela abordagem relacional, sobre a autodisciplina contratual e as prudentes estruturas de governo, ex ante ou ex post, inseridas em um ambiente contratual sabidamente tendente a uma alteração fática de cenário, no qual as partes devem, a todo tempo, desempenhar condutas ativas para restabelecer a eficiência da relação, o que na parte final deste trabalho será estudada em paralelo à eficácia da declaração negocial guardadas as circunstâncias fáticas.

Daí, com efeito, um dos principais focos desta pesquisa, qual seja o de teorizar sobre alguns outros aspectos que podem auxiliar o intérprete a buscar o fim almejado: identificar a conduta antijurídica.

Conclui-se, deste modo, terem sido expostas as premissas que podem colaborar para a compreensão e identificação do abuso de direito no exercício da denúncia unilateral.

Sendo assim, já apresentadas as ideias sobre a possibilidade de imposição judicial da prorrogação, além das reflexões sobre o abuso de direito na ruptura das relações contratuais duradouras, a terceira parte da dissertação destina-se a propor uma sistematização da interpretação do art. 473, par. ún., do Código Civil. 


\section{PARTE III - PRORROGAÇÃO COMPULSÓRIA DOS CONTRATOS DE LONGA DURAÇÃO: INTERPRETAÇÃO DO ART. 473, PAR. ÚN., DO CóDIGO CIVIL}

\section{CAPÍTULO 1 - A “NATUREZA DO CONTRATO"}

A primeira premissa fática constante da norma em apreço, vale dizer, do parágrafo único do art. 473 do Código Civil, é a "natureza do contrato". Desta forma, propõe-se na sequência demonstrar primeiramente como a regra legal é aplicável e em que escala, segundo os distintos tipos contratuais: os contratos tradicionais, por adesão ou de consumo.

Na sequência, serão formuladas considerações acerca das vicissitudes ínsitas aos contratos tradicionais e interempresariais, os quais representam o maior campo de incidência da norma em apreço.

\section{Seção I - Aplicação da norma segundo os grandes grupos contratuais}

No Brasil, há uma fragmentação razoavelmente bem delimitada dos grandes grupos contratuais.

O Direito Privado pátrio filia-se ao sistema romanístico. Sua tradição foi mantida pelo notável condicionamento histórico das fontes lusitanas medievais seguido da forte influência da obra de juristas brasileiros oitocentistas, principalmente AUGUSTO TEIXEIRA DE FreItas.

CRISTIANo ZANETTI, em estudo específico, explica que o sistema brasileiro, mormente com o advento do Código Civil de 2002, é dividido em três grandes tipos contratuais: os contratos tradicionais, os contratos por adesão e os contratos de consumo ${ }^{213}$.

A liberdade contratual em contratos tradicionais é a menos limitada. Sob ela recaem estritamente os parâmetros clássicos: licitude, ordem pública e bons costumes,

${ }^{213}$ C. S. ZANETTI, Direito contratual contemporâneo - a liberdade contratual e sua fragmentação, Rio de Janeiro/São Paulo, Forense/Método, 2008, p. 271. 
além de critérios modernos, como a boa-fé objetiva e a função social, esta última de difícil conceituação $^{214}$.

Aduza-se que, sob a perspectiva dogmática, a boa-fé e a função social não devem ser reputadas critérios para limitação do parâmetro de licitude, a exemplo do que concluíam os romanos, uma vez que as premissas são distintas. A função principal, nos ordenamentos jurídicos modernos, é a de implicar restrições de conduta específicas em prol de uma justa composição de interesses extraídos, de um modo ou de outro, do próprio sistema ${ }^{215}$.

Quanto aos contratos por adesão, sua limitação, além daquelas já manifestadas para os contratos clássicos, é positivada pelo art. 424 do Código Civil, lembrando CRISTIANO ZANETTI que tal regra ainda não foi devidamente estudada ${ }^{216}$. Aqui não se incluem os contratos de consumo, uma vez que diuturnamente são celebrados contratos por adesão entre agentes econômicos que não são consumidores.

Já sobre os contratos de consumo, é proibida a inserção de diversas cláusulas, em especial aquelas previstas no art. 51 do Código de Defesa do Consumidor, o qual estipula um sistema protetivo, criado precisamente para evitar exploração da vulnerabilidade do cidadão. A liberdade contratual é, portanto, limitada em muito maior escala nas relações de consumo.

A doutrina de CRISTIANO ZANETTI foi desenvolvida num momento no qual a exaltação dos princípios modernos contratuais tornaram-se menos exaltados, mormente quanto àqueles sociais, como o da boa-fé objetiva.

Exemplo marcante desse fenômeno constitui a classificação que busca dividir os contratos em duas grandes categorias: "de lucro" e "existenciais".

\footnotetext{
${ }^{214}$ C. S. ZANETTI, Direito...cit., p. 275.

${ }^{215}$ Cf. J. S. RIBEIRO, O problema... cit., p. 553.

${ }^{216}$ C. S. ZANETTI, Direito...cit., p. 271.
} 
Considerando-se a moderna realidade complexa, é proposta um novo quadro da tipologia contratual, reputando-se insuficientes a tradicional dicotomia entre contratos de adesão, paritários ou comuns e de consumo ${ }^{217}$.

Ressalve-se, por oportuno, que esse novo discrimen não busca substituir outras divisões dos tipos contratuais, mas antes pretende "conciliar o funcionamento estável da economia e um desenvolvimento econômico cego ao valor da pessoa humana",218.

Esse novel desenho foi sugerido por JunQueIRA DE AZEvedo. Cabe aqui transcrever a seguinte passagem de sua obra:

"Por contrato empresarial há de se entender o contrato entre empresários, pessoas físicas ou jurídicas, ou, ainda, o contrato entre um empresário e um não-empresário que, porém, naquele contrato, visa obter lucro. O contrato existencial, por sua vez, é aquele entre pessoas nãoempresárias, desde que esta naturalmente não pretenda transferir, com intuito de lucro, os efeitos do contrato para terceiros. O critério da distinção é exclusivamente subjetivo, se possível, ou, se não, subjetivoobjetivo. São existenciais, por exemplo, todos os contratos de consumo (o consumidor é o destinatário final das vantagens contratuais ou não visa obter lucro), o contrato de trabalho, o de aquisição da casa própria, o de locação da casa própria, o de conta corrente bancária e assim por diante." 219

Observa-se que o funcionamento eficaz da operabilidade, um dos três pilares do Código Civil, é alcançado certamente pela aplicação das cláusulas gerais que integram os negócios jurídicos, unido à função promocional da socialidade e da eticidade; os outros dois núcleos formadores do sistema de Direito Privado brasileiro.

\footnotetext{
${ }^{217}$ V., a respeito, A. JUNQUEIRA DE AZEVEDO, Relatório brasileiro sobre revisão contratual apresentado para as jornadas brasileiras da Associação Henri Capitant, in Novos estudos... cit., p. 182-199 e M. F. Morsello, Contratos existenciais e de lucro. Análise sob a ótica dos princípios contratuais contemporâneos, in Temas relevantes do Direito Civil contemporâneo, coords. Renan Lotufo, Giovanni Nanni e Fernando Martins, São Paulo, Atlas, 2012, p. 292-307.

${ }^{218}$ A. JUNQUEIRA DE AZEVEDO, Relatório... cit., p. 185.

${ }^{219}$ Relatório... cit., p. 186.
} 
Essa sistemática funciona de forma distinta no âmbito do ordenamento brasileiro, vale dizer, haverá momentos em que a eficácia da operabilidade guardará papel menos relevante do que os princípios sociais e vice-versa.

Exemplo dessa realidade é encontrado na própria imbricação distinta dos princípios contratuais nos mencionados contratos existenciais e de lucro. Nos contratos existenciais, à luz do primado da dignidade da pessoa humana, os princípios sociais são mais latentes. Já nos contratos de lucro, relações não marcadas por hipossuficiência e insertas em ambiente interempresarial, verifica-se menor grau de incidência dos princípios sociais, como a boa-fé, a função social, embora não seja caso de total elisão ${ }^{220}$.

Não se está a afirmar que os princípios contratuais sociais revestem-se de outra faceta quando aplicados às relações de lucro. Na verdade, a influência de tais princípios é menor quando os agentes visam ao lucro.

É certo que toda relação jurídica possui um padrão ético de conduta (resultante da boa-fé objetiva), porém, se o lucro é o objetivo almejado, presume-se que a parte está apta a fazer concessões e flexibilizar a onerosidade de sua performance. O intérprete deve ater-se às disposições contratuais e, somente no limiar do aceitável, influenciar na vontade das partes por decorrência da boa-fé objetiva.

Tal constatação pode ser elucidada com um exemplo: tome-se um contrato de compra e venda de um aparelho eletrodoméstico. Certamente, dado o sistema de defesa do consumidor, as partes não podem, por exemplo, fazer concessões sobre a imperiosidade de manutenção decorrente de vícios de qualquer natureza (cf. art. 51, I, do Código de Defesa do Consumidor).

Em um contrato de lucro, por sua vez, é perfeitamente lícito diminuir, atenuar ou renunciar direitos decorrentes de manutenção do bem objeto do negócio. Sendo assim, pouco importa que o standard esperado em tal relação engloba certo nível razoável de

${ }^{220}$ Cf. M. F. Morsello, Contratos... cit., p. 293: "Desse modo, levando em conta o primado da dignidade da pessoa humana, princípio fundante com função iluminante, que se espraia por todo sistema jurídico, os contratos existenciais imporão ao hermeneuta em juízo de ponderação maior densidade na aplicação dos denominados princípios sociais do contrato, quando cotejados com a autonomia privada. Por outro lado, certamente não escapará ao observador arguto que, nos denominados contratos de lucro, fulcrados em componente interempresarial destituído de qualquer hipossuficiência, a autonomia privada terá maior peso e interesse quando sopesada com os demais princípios, nomeadamente sociais, que, embora não elididos, terão aplicação em menor grau, sob pena de obstaculizar o tráfego contratual, com efetivo spreading indevido para o corpo social". 
manutenção. É lícito condescender com disposições acerca da ausência/diminuição de responsabilidade pelo vício da coisa.

Tal registro, contudo, não impede que, caso o contrato de lucro tenha sido entabulado com a previsão de responsabilidade pelo vício do bem, as obrigações adstritas a tal responsabilidade possam desrespeitar padrões mínimos de conduta à luz do princípio da boa-fé objetiva.

Este é um exemplo da influência distinta da boa-fé objetiva em relações sem hipossuficiência. As obrigações, muitas vezes, podem até ser alteradas ou extirpadas da relação, mas, quando convencionadas, devem sempre estar em consonância com certo padrão mínimo de conduta.

Já no que toca à resilição abusiva, reconhece-se que a sistemática do art. 473, par. ún., do Código Civil será aplicável com muito mais frequência nas situações em que o contrato seja de lucro, pois os contratos existenciais independem de investimentos.

No mais, sobre os contratos por adesão, por vezes, eles serão revestidos de sensível complexidade. Ainda assim, serão nulas as cláusulas que importem renúncia do aderente a direitos decorrentes da natureza do negócio.

Ocorre que a obrigação de respeitar um aviso prévio condizente com os investimentos da contraparte não deve ser considerada um "direito resultante da natureza do negócio”.

Lembre-se dos elementos do negócio jurídico. Existem elementos gerais, essenciais e particulares. Os elementos gerais podem ser divididos em intrínsecos (ou constitutivos) como a forma, o objeto e as circunstâncias negociais ou extrínsecos como o agente, o lugar e o tempo. Sem eles, não há negócio jurídico. Os elementos categoriais são divididos em essenciais (inderrogáveis) e naturais (derrogáveis). Já os elementos particulares podem comparecer em qualquer negócio, sendo seus exemplos a condição, o termo e o encargo ${ }^{221}$.

${ }^{221}$ C. S. ZANETTI, Direito... cit., p. 238-239, com base na classificação de A. JUnQUEIRA DE AZEVEDO, Negócio... cit., p.31-40. 
Como pondera Cristiano ZanetTi, o art. 424 do Código Civil refere-se aos elementos categoriais derrogáveis ou naturais ${ }^{222}$.

Sem os elementos gerais, sequer existiria qualquer negócio jurídico. Os elementos categoriais essenciais como, por exemplo, a coisa, o preço e o consenso no caso do contrato de compra e venda, não dependem da vontade das partes. Tais elementos são, portanto, inafastáveis, seja no contrato por adesão ou não.

Já os elementos particulares são admissíveis em qualquer negócio jurídico. Não se pode concluir que certo termo, condição ou encargo são decorrentes da natureza de determinado negócio.

Em contratos por adesão, portanto, são consideradas nulas cláusulas que versem sobre elementos categoriais naturais dos negócios jurídicos, como, por exemplo, a responsabilidade pela evicção no caso da compra e venda, ou o benefício de ordem no caso da fiança ${ }^{223}$.

Conclui-se, assim, que a compatibilização do aviso prévio com os investimentos empreendidos constitui uma obrigação que também é admitida em contratos por adesão, uma vez que diz respeito a elementos particulares do negócio jurídico. A resilição unilateral é cláusula que virtualmente pode ser inserida em qualquer negócio jurídico.

Logo, concorda-se com a classificação de contratos tradicionais, por adesão e de consumo ${ }^{224}$. Ocorre que, para os fins deste trabalho, a distinção entre contratos de lucro

${ }^{222}$ Direito... cit., p. 239.

${ }^{223}$ V. outros vários exemplos em C. S. ZANETTI, Direito... cit., p. 247-266.

${ }^{224}$ V., a respeito, C. S. ZANETTI, Direito... cit., p. 266: "Desse modo, no direito brasileiro vigente, impõe diferenciar entre os contratos submetidos aos limites clássicos, os contratos civis concluídos por adesão e os contratos que disciplinam relações de consumo. As limitações à liberdade contratual se manifestam de maneira diferenciada em cada um deles. Não se trata de simples expansão do milenar limite da licitude, mas sim de verdadeira fissura na liberdade contratual, visto que não se está a regular de modo diferenciado apenas dados contratos. Praticamente todos os contratos, típicos ou atípicos, podem ser pactuados entre consumidores ou sob a forma de adesão. Disso decorre a fragmentação da liberdade contratual no direito brasileiro. Mais do que um contrato submetido a limites gerais, existem três contratos, sujeitos a diferentes regramentos. O conceito geral de contrato, legado ao direito brasileiro pela tradição, não mais exerce seu papel centralizador na definição dos limites da liberdade contratual. Necessário, sempre, precisar se o contrato é por adesão ou de consumo. Somente quando isto não ocorrer, incidirão com exclusividade os limites clássicos previstos no Código Civil”. 
e existenciais é mais didática, porque o art. 473, par. ún., do Código Civil, tem incidência apenas nos contratos de lucros e não naqueles existenciais.

Sob diferente enfoque, importa frisar que é o próprio parágrafo único do art. 473 que, de forma cogente, determina que o aviso prévio deve ser condizente com os investimentos empreendidos pela contraparte.

Logo, mesmo nas relações de lucro, é vedado realizar concessões sobre a impossibilidade de aproveitamento dos investimentos por denúncia abrupta do contrato.

Se no campo dos contratos de lucro, os princípios contratuais sociais exercem função de menor ingerência em prestígio da autonomia privada e da liberdade contratual, há uma exceção em matéria de aviso prévio, pois, a fim de coibir a extinção abrupta, pela norma introduzida no art. 473, par. ún., do Código Civil, a função reativa do princípio da boa-fé exerce tremenda influência sobre o comportamento das partes.

Pode-se dizer que, em contratos de lucro, por decorrência direta da norma ora em estudo, a resilição é ato cuja limitação é maior quando comparada a outras faculdades contratuais.

Já no que toca aos contratos de consumo, tais relações não estão insensíveis à possibilidade de abusividade da resilição unilateral. São por outros fundamentos, todavia, que o exercício irregular de um direito será geralmente constatado, como, por exemplo, por força do moderno conceito de "catividade" nas relações consumeristas de longa duração.

Cláudia lima MARQUeS debruçou-se sobre a figura denominada "contratos cativos de longa duração", os quais seriam identificados nas relações contratuais em que são utilizados métodos de contratação de massa como contratos por adesão ou condições gerais previamente formuladas para estabelecer vínculos de longa duração. Acrescente-se que nestas relações há uma cadeia de fornecedores organizados entre si, restando, por fim, a característica dominante: 'a posição de 'catividade' ou 'dependência' dos clientes, consumidores" 225 .

Conforme as lições da autora, a noção de "catividade" deve ser contextualizada na sociedade moderna na qual existe uma série de serviços que buscam assegurar ao

${ }^{225}$ C. L. MARQUES, Contratos...cit., p. 96. 
consumidor e à sua família indispensáveis recursos como status, segurança, saúde, educação, crédito renovado.

Os principais exemplos seriam as "novas relações banco-cliente, os contratos de seguro-saúde e de assistência, médico-hospitalar, os contratos de previdência privada, os contratos de uso de cartão de crédito, os seguros em geral, os serviços de organização e aproximação de interessados (como os exercidos pelas empresas de consórcio e imobiliárias), os serviços de transmissão de informações e lazer por cabo, telefone, televisão, computadores, assim como os conhecidos serviços públicos básicos, de fornecimento de água, luz, telefone por entes públicos ou privados"226.

ClAUdia LiMA MARQUES ${ }^{227}$ lembra também que a abordagem relacional do contrato é ulterior fundamento a legitimar as obrigações decorrentes do conceito de "catividade".

Em que pese a remição da autora à abordagem relacional do contrato em matéria de relações de consumo, é importante frisar que tal abordagem, de forma geral, não foi proposta para a proteção do consumidor. Ela antes anseia a eficácia dos elementos nãopromissórios (leia-se: as disposições não escritas) da relação contratual.

A dita "catividade" patenteia-se como substrato teórico a justificar a proteção do consumidor vulnerável em relações contratuais de longa duração. Constata-se que nos contratos acima exemplificados por ClAUDIA LIMA MARQUES, o consumidor encontra-se em situação de dependência ainda maior em relação ao fornecedor. Os "contrato cativos" englobam situações cujo interesse do consumidor é virtualmente eterno, tamanha a essencialidade do bem objeto do contrato. Em sendo assim, nada mais natural do que um amparo estatal ainda mais aguçado.

Essa ilação, indubitavelmente, associa-se às premissas da abordagem relacional. Vislumbrar a "catividade" de dada relação contratual pode significar o mesmo que reconhecer a eficácia dos elementos não-promissórios dos contratos ou as circunstâncias negociais envoltas ao liame jurídico.

\footnotetext{
${ }^{226}$ C. L. MARQUES, Contratos...cit., p. 96.

${ }^{227}$ Contratos... cit., p. 101-103.
} 
Ocorre que, nos limites desta pesquisa, a vinculação da abordagem relacional à noção de "catividade" é desnecessária. Está claro que tanto em contratos de lucro quanto em contrato existenciais, é crescente o prestígio das teorias que preconizam o alcance efetivo das circunstâncias negociais não escritas.

A "catividade", no entanto, advém da própria proteção ao consumidor. Já as virtudes do contrato relacional, como visto, são englobadas pela imprescindibilidade de maior eficiência na alocação de recursos mediante as trocas. Não se busca proteger o contratante vulnerável, mas sim introduzir maior eficiência às relações contratuais, ensejando, em última instância, maior bem-estar social.

Não se busca, com essa constatação, negar qualquer imbricação da abordagem relacional na seara consumerista. Pretende-se, apenas, esclarecer que não há necessidade de estender às relações de consumo os efeitos propagados pela abordagem relacional, pois o mesmo resultado pode ser alcançado por força da proteção ao consumidor.

A matéria não é pacífica. Destaque-se, inclusive, que o próprio Superior Tribunal de Justiça teve a oportunidade de produzir precedente no qual a teoria dos contratos relacionais veio debatida em demanda da área consumerista de forma a ser comparada com o conceito de "catividade".

Tratava-se de hipótese na qual a pretensão de um segurado de vida era a de manter o vínculo contratual, após a seguradora manifestar sua intenção de resilir/revisar o contrato. $\mathrm{O}$ aresto é relativamente recente ${ }^{1}$ sendo que o voto-condutor foi seguido de seis votos-vista, circunstância que bem demonstra a complexidade do tema. A íntegra do julgado, proferido no Recurso Especial n. 1.073.595-MG chegou a oitenta e uma laudas, das quais alguns trechos da profícua discussão merecem destaque:

- do voto da Ministra Relatora NANCY ANDRIGHI (reconhecendo o contrato relacional):

“Todo esse raciocínio, em que pese ser coerente tendo em vista os pressupostos de que parte, acaba por desconsiderar um dado fundamental desta controvérsia. O contrato sub judice não pode, em hipótese alguma, ser analisado isoladamente, como um acordo de vontades voltado ao estabelecimento de obrigações recíprocas por um período fixo, com faculdade de não renovação. Essa ideia, identificada com o que Ronaldo 
Porto Macedo Jr. chamou de 'contratos descontínuos', põe de lado a percepção fundamental de que qualquer contrato de seguro oferecido ao consumidor, notadamente por um longo período ininterrupto de tempo, integra o rol de contratos que a doutrina mais autorizada convencionou chamar de contratos relacionais."

- do voto-vista do Ministro JoÃo OtAVIO Noronha (afastando a hipótese de contrato relacional):

"Ora, se a seguradora ofertou outros planos, não cabe, nesta etapa, ignorá-los para simplesmente determinar que a seguradora elabore outros, pois essa não é pretensão do autor, que, repito, deixou clara sua intenção de renovar o seguro nos mesmos patamares de custos com os quais vinha arcando.

Com relação ao mérito da questão, não tenho objeção quanto à tese desenvolvida pela i. Relatora acerca dos contratos relacionais; todavia, entendo que não comporta aplicação na espécie. Num estudo desenvolvido por Eloíza Prado de Melo, que, inclusive fora disponibilizado na internet (www.jus2.uol.com.br), a autora indica que os contratos relacionais são de longa duração por se inclinarem a criar relações contínuas e duradouras, sendo que as cláusulas regulamentam processos de negociações sucessivas. Afirma a autora que os contratos relacionais englobam relações difíceis entre diversas partes, nos quais os vínculos pessoais de solidariedade, confiança e cooperação são determinantes."

De tudo, não se admite que o art. 473, par. ún, do Código Civil, a despeito de inserir no sistema norma cuja aplicação implica a condecoração da eficácia de elementos não-promissórios, é aplicável às relações de consumo, até porque a premissa fática da norma é avessa às relações de consumo.

O pressuposto fático para o protraimento do aviso prévio é a verificação de investimentos incorridos para a perenidade do vínculo. O contrato de consumo, por excelência, não está adstrito à realização de investimento algum por parte de consumidor, precisamente porque o lucro não é visado. 
Assim, conclui-se que a "natureza do contrato", nos termos do indigitado art. 473, par. ún., deve ser interpretada como conceito específico que, na seara dos contratos de lucro, induz os contratantes a respeitarem o aviso prévio de modo compatível com os investimentos realizados pela contraparte, inclusive em certos casos de contratação por adesão.

Não é apenas esse aspecto, contudo, que encerra a matéria sobre a interpretação sistemática da expressão "natureza do contrato", uma vez que, como acima observado, existem várias outras peculiaridades que qualificam a "natureza" dos contratos, nos quais deve ser respeitado o prazo justo de aviso prévio.

\section{Seção II - Alteração do comportamento das partes durante a relação contratual}

Com acentuada probabilidade, em toda relação contratual de longa duração existem momentos de maior ou menor interação entre as partes. Seja pela necessidade de troca de informações, seja porque a relação demanda renegociação de tempos em tempos.

Dependendo da relação, sabe-se quando ocorrerá ciclos de maior ou menor aproximação. Já, em outras relações, o momento de maior interação não é pré-determinado nem ocorre em intervalos determinados, mas somente quando a relação o exigir. Considerar o momento do ciclo em que o contratante pretende deixar o contrato é tarefa deveras relevante para eventualmente diagnosticar a abusividade de conduta ou até mesmo estipular o prazo razoável de prorrogação.

A relação contratual duradoura, muitas vezes, estará em constante formação, em maior ou menor escala ${ }^{228}$. Ao contrário da ótica voluntarista, a relação não está perfeitamente delineada quando exaradas as declarações de vontade. Os contratos de longa duração podem seguir estritamente o acordo convencionado; todavia, existem casos, dada a

\footnotetext{
${ }^{228}$ V., a respeito, P. D. R. ARAUJO, Prorrogação... cit., p. 73: "Diante disso, afirma-se que o contrato ou a relação contratual de longa duração está em constante formação. Não há propriamente um único momento em que todas as regras e condições contratuais estão definidas, como queriam os voluntaristas. Há uma combinação construtiva entre o contrato e o tempo, que permita ao contrato superar os obstáculos ligados à inconstância do tempo, permitindo assim sua evolução ao longo da duração da relação jurídico-contratual. O pacto contratual vai sendo construído pelas partes ao longo do tempo, conforme a relação jurídica entres elas se desenvolve”.
} 
natureza do vínculo, nos quais a relação desenvolve-se paulatinamente e o vínculo jurídico está em constante formação.

Nem sempre será assim. Imagine-se, por exemplo, um contrato de locação predial, exemplo genuíno de relação contratual duradoura. O vínculo contratual, como definido no momento da formação, não é alterado, não está em constante evolução.

Não obstante, sabe-se que a legislação específica sobre locação de prédios urbanos ou rurais predispõe períodos mínimos de contratação. A influência do aspecto temporal, no entanto, nada diz respeito à natureza do contrato, mas antes ao bem da vida objeto de consenso (uso da propriedade imobiliária).

Não existem ou quase não existem momentos de maior ou menor aproximação se não para uma possível renovação ou em casos excepcionais para tratar de uma benfeitoria ou custos extraordinários. Na prática, dificilmente haverá um momento específico em que a ruptura contratual será injustamente benéfica para certa parte (e, portanto, ilícita).

Tanto no Brasil quanto em outras sociedades, existem situações nas quais a legislação fixa um termo mínimo ou máximo contratual, mas, em regra, a norma não protege o contratante da influência exclusiva do aspecto temporal. Procura-se, como no caso do termo mínimo no contrato de locação predial, tutelar o interesse de terceiros ou das partes em razão de um aproveitamento mínimo desejado pela lei.

JACQUES AZÉMA, em monografia específica, discorreu de forma extensa sobre inúmeras situações, verificadas em França, acerca de limites de duração mínima ou máxima do contrato para tutelar ora o interesse da sociedade, ora o interesse das partes ou até mesmo proteger os interesses de uma parte em relação à outra.

As limitações de interesse geral estariam exemplificadas no limite de cinco anos da cláusula de retrovenda (art. 1.660 do Code Civil); dez anos para o contrato de fornecimento exclusivo e cinco anos para o contrato exclusivo de cessão de direitos de um "auteur dramatique" para um "entrepeneur de spectacles" (cessão de direitos autorais patrimoniais) $^{229}$.

${ }^{229}$ V. La durée... cit., p. 32-41. 
Ademais, quanto às hipóteses em que a limitação temporal tutela o interesse particular, o doutrinador francês invoca a duração máxima de cinco anos das convenções coletivas e o mesmo período para a cláusula de indivisibilidade do bem comum. Em seguida, os exemplos para a tutela dos interesses de uma parte em relação aos da outra nos casos de limitação de um ano para o contrato verbal de trabalho e nove anos para a locação predial por pessoa que não é proprietária (usufrutuário, curador ou tutor do proprietário) ${ }^{230}$.

Nas situações acima retratadas, o tempo influencia o programa contratual como verdadeiro instrumento de tutela estatal. O termo máximo ou mínimo é definido em lei como forma de proteger interesses.

Ocorre que o decurso do tempo, em certas relações de longa duração, não influencia a relação contratual somente para proteger o bem da vida objeto do contrato. Como já adiantado, alude-se aos casos em que o vínculo contratual está em constante formação.

Tome-se um contrato de fornecimento de alimentos para a venda de produtos industrializados, e. g., o extrato de cacau para uma fábrica de chocolates. Se as partes conseguem atingir a eficiência desejada com a precisa fixação ex ante da quantidade, qualidade e local do fornecimento, o contrato estará dotado de estabilidade, vale dizer, seria um contrato completo (segundo a denominação advinda da teoria incompletude contratual)

Em um cenário de estabilidade, repita-se, constitui tarefa árdua verificar o momento em que a ruptura unilateral seja incompatível com o padrão de conduta esperado para tal contratante ou, em última análise, com o prazo estipulado de aviso prévio.

Em muitos casos, contudo, por decorrência de uma sociedade cada vez mais complexa, com escassez de recursos, assimetria de informações e racionalidade limitada, a prévia definição de futuras trocas não atinge a alocação eficiente de recursos no grau desejado, como observado na segunda parte deste estudo. Resta às partes definir de que modo poderão envidar esforços mútuos para melhorar a eficiência contratual.

${ }^{230}$ V. La durée... cit., p. 41-50. 
Para muitos e para a cultura geral (pelo menos, no Brasil), a melhor solução está em incluir no instrumento contratual o maior número possível de disposições definindo, ao máximo, qual deverá ser a performance efetiva de cada uma das partes.

Muitas vezes, tal previsão será dificilmente alcançada ou, ao menos, a predisposição fixa e imutável do programa contratual futuro possivelmente obstará a eficiência razoável desejada pelas partes com a celebração do contrato.

Novamente, sobre o exemplo do fornecimento de extrato de cacau para a indústria de chocolate, suponha-se que a fábrica de chocolates venha percebendo nos últimos anos aumento mais ou menos uniforme em suas vendas, o que consequentemente tem demandado aumento da produção do fornecedor.

O aviso prévio em caso de resilição unilateral foi acordado em contrato estipulando-se o prazo de 90 dias, uma vez que este era o tempo médio entre a matéria prima ser plantada, colhida e entregue na fábrica.

Pois bem, em meio ao cenário de aumento da produção, a fábrica denuncia o contrato e imediatamente a fornecedora demonstra irresignação alegando que o prazo de 90 dias é muito exíguo, considerando os investimentos realizados nos últimos tempos em decorrência direta do constante aumento da produção. A fábrica, por sua vez, aduz que a fornecedora sempre teve conhecimento do prazo de aviso prévio e se o seu investimento não pode ser percebido em 90 dias é porque assumiu tal risco.

Repita-se: numa relação estável, dificilmente o prazo de 90 dias seria reputado injusto, muito menos seria a extinção do contrato considerada abrupta.

Desse modo impõe-se a seguinte indagação: o aumento (constante e por um período significativo) do volume contratado pode ter alterado o período de aviso prévio compatível aos investimentos da parte denunciada?

Para responder a esta questão, reputa-se essencial relembrar algumas ideias a respeito da declaração de vontade nos negócios jurídicos, o que JUNQUEIRA DE AZEVEDO 
cunhou como "declaração negocial" "231 (é nesta seara que o paralelo com a abordagem relacional do contrato é latente).

JUNQUEIRA DE AZEVEDO invoca um clássico exemplo ${ }^{232}$ : imagine-se um leilão de antiguidades, sendo realizado em um salão repleto de assentos no qual o leiloeiro apregoa certo objeto para ser leiloado. O leiloeiro inicia o conhecido procedimento bradando em voz alta o valor do lance a cada momento. Algumas pessoas da plateia gesticulam atendendo aos lances anunciados pelo leiloeiro até que ninguém mais "levanta a mão".

Nas palavras de PAUlo ARAúJo: "Ninguém tem dúvida que cada uma das pessoas que levantou a mão fez uma oferta (negócio jurídico unilateral receptício cujo objetivo é a formação de um contrato). Ninguém tem dúvidas de que aquele que der o maior lance celebrará um contrato de compra e venda com o proprietário do objeto leiloado, obrigando-se a pagar o preço ofertado e adquirindo o direito de receber a coisa leiloada. ${ }^{, 233}$.

Em seguida, tome-se o mesmo exemplo exatamente naquele salão ainda repleto de assentos, também com um sujeito a frente da plateia e, de forma semelhante, algumas pessoas levantam a mão. Trata-se de uma palestra. As pessoas estão erguendo os braços para interromper a explanação e proferir perguntas. Não há dúvida quanto à irrelevância de tais gestos para o mundo jurídico.

A ilustração serve para demonstrar como o mesmo ato ("levantar a mão"), em um idêntico cenário, implica consequências completamente distintas a depender do contexto circunstancial que se insere.

A declaração de vontade só produz efeitos jurídicos se guardadas as circunstâncias negociais, ou, segundo as lições de IAN MACNEIL, é necessária a atenção aos elementos não-promissórios do contrato. Lembre-se dos exemplos: "status, papel social, parentesco, hábitos, padrões burocráticos, etc.".

\footnotetext{
${ }^{231}$ Negócio jurídico e declaração negocial, São Paulo, Saraiva, 1986, principalmente p. 20-25.

${ }^{232}$ Prorrogação... cit., p. 194-196.

${ }^{233}$ Prorrogação... cit., p. 195.
} 
As circunstâncias negociais, por sua vez, não dependem de fatores axiológicos. Não há a priori um cenário em que uma declaração de vontade sempre produzirá efeitos jurídicos. É preciso verificar o contexto fático em que ela se insere, o que é realizado segundo um exercício hermenêutico pelo qual se presume o consenso de terceiros sobre a eventual eficácia jurídica da declaração.

É certo, contudo, que a vontade e a consciência do declarante também exercem papel fundamental no suporte fático apto a produzir efeitos jurídicos. Torna-se necessário destarte voltar-se às teorias desenvolvidas sobre a declaração, as quais, no precedente paradigma, eram totalmente deslocadas para o plano da validade dos negócios jurídicos, pois estavam inseridas na categoria dos vícios do negócio jurídico (erro). As mais célebres teorias seriam a da vontade, a da declaração, da responsabilidade e da confiança.

Não há necessidade, entretanto, de invocar-se estas teorias, bastando dizer que se prestigia hodiernamente a teoria da confiança pela qual o aspecto volitivo do declarante está em justaposição com a cognoscibilidade daquele que recebe a declaração.

Consoante o art. 138, reforçado pelo art. 113 do Código Civil, as declarações negociais são perfeitamente válidas e eficazes quando passíveis de ser compreendidas por ambas as partes, conforme o que "poderia ser percebido por pessoa de diligência normal, em face das circunstâncias do negócio” (art. 138).

Recorde-se que, em um parecer sobre esta matéria, Gustavo TEPEDINO assim definiu o atual estado da arte: "Consagrada no Código Civil de 2002 a teoria da confiança, pode-se afirmar, com renovado vigor, que, na interpretação das diversas cláusulas de um contrato, devem-se considerar vinculantes os deveres que, manifestados pelas partes, suscitam em ambas uma compreensão comum quanto ao conteúdo da declaração. "234

Com efeito, restando evidenciada a "compreensão comum quanto ao conteúdo da declaração”, não há ulteriores óbices ao reconhecimento da validade e eficácia da declaração negocial.

${ }^{234}$ Novos princípios contratuais e teoria da confiança: a exegese da cláusula to the best knowledge of the sellers, disponível em http://www.tepedino.adv.br/wp/wp-content/uploads/2012/09/biblioteca13.pdf - acesso em 27 de novembro de 2013. 
Sobre este ponto, é válida a oportuna observação de VINCENZO ROPPO no sentido de que modernamente a boa-fé limita o comportamento dos contratantes tanto no plano da validade (por exemplo, art. 138 do CC), quanto também no plano da eficácia, acarretando responsabilidade das partes ${ }^{235}$, o que, no Brasil, é embasado pelas normas previstas nos arts. 113 e 422 do Código Civil.

Feita a ressalva, frise-se, portanto, que ao averiguar se a declaração da vontade era apta a gerar uma "compreensão comum" segundo as circunstâncias do negócio, faz-se imperioso o socorro à cláusula geral da boa-fé objetiva pela qual é normativo o respeito a um padrão esperado de conduta para determinado negócio.

No mesmo sentido, PAUlo ARAúJO discorrendo sobre aquilo que denominou “alteração do enunciado contratual por meio de declarações negociais tácitas”, também conclui que é preciso deslocar o foco de concentração nos padrões gerais de conduta legitimado pela boa-fé objetiva ${ }^{236}$ e não mais na mera relação entre a vontade do declarante e sua declaração.

Ressalve-se, todavia, que a "compreensão comum" não será exatamente igual ao conteúdo da declaração negocial, tampouco será a priori idêntica à compreensão de quem recebe a declaração. Tome-se uma declaração negocial, cujo conteúdo exige investimentos da contraparte na ordem de $\mathrm{R} \$ 100,00$ (segundo a compreensão do de quem recebeu a declaração). O declarante, por sua vez, entende que a contraparte deverá empreender um investimento de $\mathrm{R} \$ 60,00$.

Nada impede que o intérprete verifique que, segundo as circunstâncias negociais, a "compreensão comum" decorrente da declaração negocial justifica um investimento de R\$80,00. É o que KARL LARENZ chamou de "significado normativo da

\footnotetext{
${ }^{235}$ V. Il contratto del... cit., p. 81-82.

236 P. D. R. ARAúJo, Prorrogação... cit., p. 209: "Diante disso, pode-se afirmar que a boa-fé objetiva, delimitação material do princípio da confiança, prevista expressamente no artigo 422 do Código Civil, é o elemento legitimador da alteração do enunciado contratual mediante comportamento concludente das partes, pois extrai da análise da conduta os aspectos subjetivos da declaração negocial, tais como a imposição de forma determinada e a consciência de juridicidade, substituindo-se pela análise dos aspectos objetivos relativos à legitimidade das expectativas criadas nas contratapartes e terceiros".
} 
declaração", o qual "não precisa estar de acordo nem com o efectivamente pensado, nem com o efectivamente entendido" ${ }^{237}$.

Feita esta observação, formula-se novamente a indagação sobre o exemplo do fornecimento de extrato de cacau: "o aumento (constante e por um período significativo) do volume contratado pode ter alterado o período de aviso prévio compatível aos investimentos da parte denunciada?".

Nesta situação, é indubitável que o prazo de 90 dias no momento da celebração do contrato, segundo as informações que as partes dispunham e compartilharam no momento da contratação, era justo e compatível às peculiaridades da relação contratual.

A despeito desse aspecto, não se pode negar que o comportamento das partes concomitantemente ao aumento do volume contratado encontra "compreensão comum" durante o desenrolar da execução contratual, o que justifica a prorrogação do aviso prévio a fim de se evitar prejuízos derivados do excedente de investimento o qual foi realizado por consequência do aumento do volume contratado.

Dessume-se, portanto, que a alteração do comportamento das partes é capaz de transformar o vínculo contratual, desde que as declarações negociais sejam passíveis de "compreensão comum" pelas partes contratantes.

Ademais, é imprescindível lembrar que a apreciação da "compreensão comum" das declarações negociais estará, como é curial, na seara de interpretação do negócio jurídico delineada por padrões de conduta decorrentes da boa-fé objetiva. Pensa-se, pois, na denominada função interpretativa da boa-fé objetiva atrelada à eficácia do tempo sobre a relação jurídica.

\footnotetext{
${ }^{237}$ Cf. Metodologia da ciência do direito, $3^{\text {a }}$ ed., trad. port. José Lamego, Lisboa, Fundação Calouste Gulbenkian, 1997, p. 421-422: "Se a declaração é, em boa verdade, susceptível de vários significados, mas declarante e declaratário, a quiserem no mesmo sentido, ambos têm de a deixar valer com este sentido; o ordenamento jurídico não tem qualquer razão para lhes impor um significado que nenhum deles tenha pretendido. Em contrapartida, se o declaratário a entendeu de modo diferente daquele que o declarante com ela queria significar, então não é juridicamente determinante, sem mais, nem o significado efectivamente intencionado nem o efectivamente percebido. A ordem jurídica tutela a confiança do declaratário a fim de que a declaração valha com o significado com que, segundo as circunstâncias, podia e devia ser entendida. Este significado é, uma vez, que não precisa de estar de acordo nem com o efectivamente pensado, nem com o efectivamente entendido, um significado normativo da declaração. Para este significado normativo da declaração é decisivo o 'horizonte de compreensão do declaratário'.".
} 
Lembre-se que a boa-fé objetiva produz efeitos sobre a relação jurídica de três maneiras: pela função interpretativa, a qual nada mais é do que a própria análise das declarações negociais conjugada à evidência de "compreensão comum"; a função ativa pela qual são revelados deveres laterais dela decorrentes e a reativa, nas ocasiões em que ela justifica a tutela contrária ao abuso de direito ${ }^{238}$.

Sendo assim, é imperioso compreender como a boa-fé objetiva intervirá na relação jurídica em matéria de extensão do aviso prévio. Sem dúvida, se a prorrogação do aviso prévio é uma defesa da parte denunciada para coibir a conduta abusiva do denunciante, a função reativa da boa-fé objetiva desenrola papel fundamental.

Segundo a definição de MENEZES CORDEIRO ${ }^{239}$, a supressio é o instituto pelo qual a ausência reiterada do exercício de uma posição jurídica implica perda da eficácia de direitos. O fator temporal é inafastável para a ocorrência do fenômeno.

No que toca à surrectio, neologismo cunhado por MENEZES CORDEIRO para traduzir outro neologismo (Erwirkung) o qual foi, pela primeira vez, sintetizado por CLAUS-WILHELM CANARIS ${ }^{240}$, ela é compreendida como a consequência da moderna percepção do fenômeno da supressio.

Não se deve analisar unicamente a ótica daquele que deixa de exercer uma posição jurídica e o tempo que tal omissão perdura. É preciso outrossim verificar a carga de confiança atribuída ao "beneficiário" para porventura justificar o nascimento de um direito.

${ }^{238}$ Cf. J. F. SIMÃo, Tempo e Direito Civil - prescrição e decadência, (tese de livre-docência-USP), São Pualo, 2011, p. 253: "Assim, a boa-fé objetiva pode ser estudada de acordo com três funções: a interpretativa (como cânone hermenêutico); a ativa (como criadora de direitos laterais ou anexos); e a reativa ou limitadora de direitos subjetivos. Em se tratando da função reativa, a boa-fé será a alegação de defesa para rechaçar determinada pretensão injusta, ou, como esclarece Menezes Cordeiro, exceção é a situação jurídica pela qual uma pessoa adstrita a um dever pode, licitamente, recusar a efetivação da pretensão correspondente. É dessa função que nascem os institutos da supressio e surrectio”. V., também, J. Martins-Costa, A boa-fé no Direito Privado, São Paulo, Ed. RT, 1999, principalmente p. 455-472.

${ }^{239}$ Cf. Da boa fé... cit., p. 1293: “Uma posição jurídica que não tenha, em determinadas circunstâncias, sido exercida durante certo lapso de tempo pode perder a sua eficácia: é a supressio; consagrada na jurisprudência, a supressio veio, depois de várias tentativas, a ser aproximada da boa-fé”.

${ }^{240}$ Como explicado pelo próprio A. M. R. Menezes CORDEIRO, Da boa fé... cit., p, 817: “Por surrectio pretende exprimir-se a ideia comportada pelo termo alemão Erwirkung é,ela própria, um neologismo proposto por Canaris, em 1971, com sucesso crescente; foi, p. ex., adoptado por Larenz, a partir da décima segunda edição do seu SchuldR e, com grande desenvolvimento, por Jurgen Schimidt, na décima segunda edição do comentário de Staudinger". 
É o que JosÉ Fernando SimÃo sintetiza como a "outra face da moeda, ou seja, a posição jurídica que passa a ser exercida em decorrência da supressio ${ }^{, 241}$.

Com estes esclarecimentos, há uma questão que se impõe: se num determinado contrato é estabelecido um aviso prévio de 30 dias, mas dadas as declarações negociais emitidas por uma ou ambas as partes, justifica-se o aumento de tal lapso temporal, pode-se concluir que houve supressio (ineficácia do direito de resilir) e surrectio (surgimento do direito de manter o vínculo contratual por mais de 30 dias)?

Nos limites desta pesquisa, a resposta é positiva, mas não pela sistemática prevista no art. 473, par. ún., do Código Civil. Explica-se.

Ressalte-se não ser impossível vislumbrar hipótese em que a ausência do exercício de uma posição jurídica gere confiança no "beneficiário", de modo a redundar maior extensão do aviso prévio.

A premissa fática imposta pelo art. 473, par. ún, é, contudo, distinta. Não se está a dizer que a função reativa da boa-fé objetiva não produz efeitos na extensão do aviso prévio. Ocorre que tais efeitos não são propagados pelos institutos da supressio ou surrectio.

É necessária a ocorrência de conduta ativa de pelo menos uma das partes ("investimentos consideráveis") de modo a se justificar a carga de confiança depositada na contraparte.

Em suma, quando o intérprete estiver diante de hipótese em que deva ser definido certo prazo de alargamento do aviso prévio, não será imperioso o cotejo da posição jurídica que deixou de ser exercida, mas apenas as declarações negociais que estimularam ambiente contratual digno de incremento de investimentos.

Não foi esse, contudo, o entendimento exarado pelo Ministro LUIS FeLIPE SALOMÃO, ao proferir, na condição de relator sorteado, voto vencido no Recurso Especial n. 1.112.796-PR, no sentido de reconhecer a conduta ilícita do denunciante, pois seu direito teria restado "enfraquecido" por ocasião das sucessivas renovações pretéritas, ensejando confiança na contraparte:

${ }^{241}$ Tempo... cit., p. 254. 
"Ou seja, a supressio inibe o exercício de um direto, até então reconhecido, pelo seu não-exercício, se presente, de outra parte, a boa-fé do contratante.

Por outro lado, em direção oposta à supressio, mas com ela intimamente ligada, tem-se a teoria da surrectio, cujo desdobramento é aquisição de um direto pelo decurso de tempo, pela expectativa legitimamente despertada. (...)

Com efeito, resta claro nos autos que o comportamento reiterado da recorrente, consistente na prorrogação contratual iterativa, por duas décadas, somando-se a isso elevados investimentos realizados pela autora em razão da aderência ao 'Projeto Excelência 2.0', a um só tempo, enfraqueceu o direito de resilição unilateral da ré e gerou legítima expectativa na autora de que aquela não mais acionaria a cláusula $13^{\mathrm{a}}$, que permita qualquer dos contratantes a resilição imotivada do contrato mediante denúncia.

A denúncia vazia realizada pela recorrente consubstancia, deveras, quebra da confiança, decorrente esta de uma realidade criada por ela própria, mediante comportamento que sinalizava, de fato, a continuidade da avença, ao menos durante um prazo razoável para a recuperação dos investimentos, ou até aonde alcança a expressão 'Excelência 2.0”,242.

Não se quer afirmar que o afastamento do substrato teórico preconizado pelo instituto da supressio ensejaria solução diversa ao caso concreto. Ocorre que o fundamento legal da "quebra de confiança" da denúncia é a própria norma do art. 473, par. ún., sem necessidade de socorro ao instituto da supressio, pois reconhecer a "ausência de exercício de posição jurídica" pelas declarações negociais aptas a ensejar investimentos pela

${ }^{242}$ Ainda sobre o REsp. n. 1.112.796- PR, ressalte-se que o voto-vista a prevalecer por maioria foi assim ementado: "CIVL. PROCESUAL CIVL. CONTRATO. VALIDADE DE CLÁSULA. CESSAÇÃO DE ATIVDADE DE DISTRIBUIÇÃO DE BEBIDAS. NÃO-RENOVAÇ̃̃O APÓS OTÉRMINO DO PRAZO PACTUADO, MEDIANTE PRÉVIA NOTIFCAÇÃO. INDENIZAÇÃO INDEVIDA.”. Neste julgado, restou decido não ser devida indenização, eis que a denúncia do contrato teria sido lícita. As bases dogmáticas fundamentadoras do dispositivo, a exemplo dos REsps. n. 493.159-SP; n. 681.100-PR; e n. 766.012-RJ, parecem estar equivocadas, pois justificam aprioristicamente a impossibilidade de prejuízos decorrentes da não renovação em contratos de distribuição quando as disposições contratuais escritas são obedecidas. Tal entendimento está ultrapassado na medida em que, há tempos, são reconhecidas novas vicissitudes nas relações de longa duração, sobretudo aquelas advindas da boa-fé objetiva. V., a respeito, a crítica de PAULO ARAUJO sobre tais precedentes. (Prorrogação... cit., p. 318-319). 
contraparte reputa-se construção dogmática desnecessariamente complicada ou até mesmo equivocada.

Nem mesmo a figura do venire contra factum proprium é suficiente para abarcar a norma do art. 473, par. ún., a despeito de a distinção ser mais tênue.

Explicar a disciplina do art. 473, par. ún., do Código Civil, pelo instituto do venire contra factum proprium, seria reconhecer o "fato próprio" na tolerância da parte que aceita o investimento da contraparte.

Existem, nos limites desta pesquisa, dois motivos para afastamento de tal construção dogmática. O primeiro forte em uma ressalva de MENEZES CoRDEIRO sobre a relevância de só reconhecer a figura do venire contra factum proprium quando o comportamento contraditório afronta diretamente o "fato próprio" ${ }^{243}$, o que não seria o caso. Para tal instituto se adequar ao caso concreto, o fato próprio estaria consubstanciado na conduta do denunciante que aceita sem ressalvas o investimento realizado pela outra parte, o que seria deveras complicado para o intérprete. O fato próprio estaria imiscuído em meio a um comportamento omissivo.

Já o segundo motivo diz respeito à própria existência do art. 473, p. ún, o qual prescreve premissas fáticas para a possibilidade de incidência da norma, sem a necessidade de auxílio a outros institutos.

Nem toda declaração negocial poderá justificar a ocorrência do diferimento do aviso prévio, mas somente aquelas adstritas ao incremento de investimentos necessários para manutenção da desejada eficiência econômica da relação jurídica.

Sendo certo que a norma prestigia a função interpretativa e reativa da boa-fé objetiva, quanto a esta, não se faz necessário o socorro às consagradas construções dogmáticas como supressio/surrectio, pois o suporte fático da norma prevê a contribuição ativa das partes, nem tampouco ao venire contra factum proprium, pois dificilmente será estabelecida uma relação direta entre o comportamento omissivo da parte e a denúncia contratual contraditória.

\footnotetext{
${ }^{243}$ Da boa fé... cit., p, 746: "Desse modo, só se considera como venire contra factum proprium a contradição directa entre a situação jurídica originada pelo factum proprium e o segundo comportamento do autor".
} 
Conclui-se, deste modo, que a alteração do comportamento das partes será motivo justificador da prorrogação do aviso prévio, desde que seja evidenciada “compreensão comum” das declarações negociais capazes de gerar investimento pela parte contrária. A boa-fé objetiva é prestigiada, mas de forma específica e não como normalmente deduzida das normas previstas no arts. 113 e 422 do Código Civil.

\section{Seção III - Obrigação de renovação ínsita às relações de longa duração}

Até aqui, foi aduzido que a alteração no comportamento das partes, quando o contexto negocial apontar para uma "compreensão comum” das declarações de vontade, é capaz de alterar o conteúdo do contrato e, portanto, justificar a imperiosidade de um aviso prévio maior do que aquele previamente acordado.

No mais, as mudanças ocorridas em uma relação de longa duração também podem justificar alteração do conteúdo do contrato por decorrência de uma obrigação genérica de renovação constante do vínculo, também legitimada pela boa-fé objetiva.

ANNE-SOPHIE LABORDERIE desenvolveu tese sobre aquilo que denominou perenidade contratual (La pérennité contractuelle) $)^{244}$, conceito que pode ser resumido como a duração ótima de um contrato.

A premissa para tanto é compreender a noção de prazo contratual de uma forma mais "ampla e flexível"245. Logo, de forma mais flexível, o prazo contratual nas relações de longa duração estaria sempre condicionado a uma nova declaração negocial das partes, forte na constante e perene obrigação implícita de renovação do contrato, a ferramenta mais importante para atingir-se a ideal pérennité contractuelle de ANNE-SOPHIE LABORDERIE.

A obrigação de renovação em prol da almejada perenidade contratual seria essencialmente a forma de utilização de um instrumento técnico e ético presente durante a execução do contrato ${ }^{246}$.

\footnotetext{
${ }^{244} \mathrm{~V}$., a respeito, sobre o conceito de perenidade contratual La pérennité... cit., especialmente p. 27-41 e 8687; e sobre a obrigação implícita de renovação dos contratos p. 416-419.

${ }^{245}$ La pérennité... cit., p. 86: "à la fois étendue et souple de la notion de durée du contrat".

${ }^{246}$ La pérennité... cit., p. 419.
} 
No mesmo sentido, Mustapha MeKKI remete a um chamado "princípio de negociação”, o qual seria particularmente forte nas relações de longa duração, pelo qual às partes seria imposta uma obrigação de negociação em prestígio da conciliação ${ }^{247}$.

Esta obrigação implícita de renovação do contrato, ademais, também pode ser inferida segundo a teoria relacional de IAN MACNEIL, a despeito de suas bases dogmáticas completamente distintas ${ }^{248}$. Lembre-se dos chamados elementos promissórios e nãopromissórios de uma declaração negocial.

A declaração negocial, guardado o contexto em que se insere, nada mais seria do que a comunicação de um compromisso futuro. Como o compromisso é assumido no futuro devem ser levados em conta quaisquer circunstâncias que alterem seu conteúdo quando do momento da execução. Embora IAN MACNEIL disserte de forma completamente distinta em relação aos estudos proveniente da Europa continental, a noção de “compreensão comum” da declaração importa a mesma relevância em sua teoria.

Como adiantado, foram LindA MULCAHY e JOHN TILOTSON ${ }^{249}$ que afirmaram categoricamente que a abordagem relacional é a outra face da moeda segundo as teorias ainda arraigadas à eficácia do contrato escrito, ou seja, os elementos de uma declaração negocial cognoscíveis por ambas as partes, escritos ou não no instrumento de contrato (leia-se: promissórios ou não-promissórios), fazem parte do conteúdo do negócio jurídico.

Se ANNE-SOPHIE LABORDERIE justifica suas proposições com base na obrigação implícita de renovação, IAN MACNEIL, de modo análogo, legitima suas pretensões teóricas na já mencionada realocação eficiente de recursos, ou seja, mais importante do que o contrato escrito é a manutenção da eficiência econômica pactuada no início da celebração.

Sendo assim, também por estes motivos (obrigação implícita de renovação e realocação eficiente de recursos), justifica-se a alteração do aviso prévio segundo as

\footnotetext{
${ }^{247}$ L'intérêt... cit., p. 801.

${ }^{248}$ V. também M. MEKKI, L'intérêt... cit., p. 731-734 sobre os contratos relacionais e implicações que dele são percebidas como, entre outras, uma obrigação de renegociação durante a execução do contrato.

${ }^{249}$ Contract Law... cit., p. 51.
} 
declarações negociais emitidas durante a relação contínua, sempre considerando que as declarações devem ser cognoscíveis por ambas as partes e não somente pela declarante.

Ademais, há uma ressalva a ser elucidada. Até aqui foram desenvolvidas noções a justificar a alteração do conteúdo contratual de forma condizente com declarações negociais emitidas durante a relação contínua, de modo a imputar confiança na contraparte, o que foi reforçado pelas ideias atinentes à obrigação de renovação e realocação eficiente de recursos.

Observa-se, contudo, que, de modo algum, olvidam-se os riscos contratuais passíveis de serem assumidos nas relações contratuais. Mormente nas relações de lucro, as partes são livres para investir na relação na ordem que entenderem e, cada uma, assumirá o risco deste investimento não retornar de forma como esperado (spreading).

Não se admite, por outro lado, que os investimentos realizados por decorrência das declarações negociais da contraparte não possam ser aproveitados por consequência da ruptura abrupta do contrato. Estas são as características dos investimentos, que devem ser tutelados seja pela responsabilidade civil, seja pela prorrogação compulsória, como será detalhado em capítulo adiante.

Finalmente, ainda sobre esta obrigação implícita de renovação, considere-se o já mencionado estudo de REINHARD ZIMMERMANN e SIMON WHITTAKER sobre a boa-fé no direito contratual europeu, no qual foi avaliada a opinião de doutrinadores de vários países do velho continente em relação a diferentes casos concretos. Dois deles diretamente ligados à potencial abusividade do direito de resilição e a possibilidade, ou não, de prorrogação compulsória ${ }^{250}$, que se analisa em imediata sequencia.

Sobre a primeira situação examinada, verifica-se que foi celebrado, em $1^{\circ}$ de janeiro de 1950, contrato de distribuição de autopeças com cláusula de exclusividade. O prazo do contrato era de um ano. Durante muito tempo, ao final de cada ano, o contrato foi expressamente renovado. Ao comprador era facultada a denúncia unilateral imotivada, desde que respeitado o aviso prévio de 30 dias.

${ }^{250}$ Cf. R. ZimMERMAnN e S. WhitTAKER, Good Faith...cit., p. 532-556. 
Em 1992, o comprador denuncia o contrato, concedendo ao fornecedor o aviso prévio de 30 dias. Pergunta-se: o contrato deve ser levado a termo? O fornecedor tem direito a alguma indenização? ${ }^{251}$.

A segunda hipótese é semelhante, com um pormenor importante: a renovação automática. Há também um contrato de distribuição celebrado em $1^{\circ}$ de janeiro de 1950. Analogamente, o prazo é anual, estipulada a renovação automática, salvo se qualquer das partes denunciar o contrato de um ano para o outro. Também foi estabelecido que a denúncia deveria ser realizada até o dia 30 de novembro, o que, de fato, acontece em $1992^{252}$.

Norteando-se pela doutrina e jurisprudência especializadas de cada país, foram formuladas respostas no âmbito do ordenamento jurídico alemão, grego, austríaco, francês, belga, espanhol, italiano, holandês, irlandês, inglês, escocês, dinamarquês, norueguês, sueco e finlandês. De todas estas experiências, importa colacionar algumas noções sobre a alemã, austríaca, francesa, italiana e inglesa.

Para os doutrinadores alemães, no que toca ao primeiro exemplo, em teoria, a conduta poderia ser considerada contraditória e, por isso, ilícita, ante a cláusula geral da boa-fé, contemplada no $§ 242$ do Código Civil ( $B G B)$, caso o vínculo contratual duradouro tivesse gerado uma expectativa razoável na continuidade da relação ${ }^{253}$.

O contrato, todavia, foi renovado a cada ano. Em todas as renovações, logicamente, toda a relação contratual foi restaurada, ou seja, a cada ano recriou-se a faculdade de denunciar o contrato com aviso prévio de 30 dias. Daí o comportamento não ser tido como contraditório.

Diferente solução foi encontrada para o subsequente conflito. O segundo contrato não foi renovado ano a ano mediante consenso das partes. Sua renovação era automática. Logo, vislumbrou-se uma relação contínua e perene há décadas, reconhecendo-se a expectativa relevante na continuação da relação contratual. Desse

\footnotetext{
${ }^{251}$ Cf. R. Zimmermann e S. WhitTAKER, Good Faith ... cit., p. 532.

${ }^{252}$ Cf. R. ZimMERMANN e S. WhITTAKER, Good Faith ... cit., p. 546.

${ }^{253}$ Cf. R. ZimMERMANN e S. WhitTAKER, Good Faith ... cit., p. 532.
} 
modo, o direito à resilição unilateral foi limitado. Melhor do que a solução em perdas e danos, foi considerada a prorrogação do contrato.

O prazo sugerido (sem indicação de critérios) foi o de um ano a contar da denúncia. Por fim, ainda houve a ressalva de que o contrato deveria ser fielmente cumprido enquanto compulsoriamente prorrogado, sob pena de o fornecedor ser condenado ao pagamento de perdas e danos decorrentes de eventual inadimplência ${ }^{254}$.

No ordenamento austríaco, por outro lado, quanto ao primeiro dos casos apresentados, não haveria como justificar qualquer direito do fornecedor, principalmente porque o contrato foi renovado ano a ano. Logo, o vínculo e as expectativas das partes foram também renovadas. Tanto para prorrogação do contrato quanto para eventual direito a indenização a perdas e danos são exigidos indícios de que o comportamento de uma das partes induziu a outra a tomar uma atitude equivocada perante a intenção de resilição.

Analogamente à solução alemã, segundo os especialistas austríacos, uma ação indenizatória teria boas chances de sucesso na outra situação. A renovação automática do vínculo produz os mesmos efeitos de uma relação contínua. Não há renovação propriamente dita. Há continuação. Seria, portanto, necessária a prova de que a parte denunciada teria "arranged his affairs as a result",255 da manutenção do vínculo contratual.

Idênticas soluções atreladas à distinção entre renovação automática expressa do contrato também são observadas no âmbito do sistema francês ${ }^{256}$, mormente se identificado o abuso do direito de resilir, o qual também estaria balizado pela boa-fé nos termos do art. 1.134, al. 3, do Code Civil $^{257}$. Importa salientar que a doutrina dos civilistas franceses

${ }^{254}$ Cf. R. ZimMERMANN e S. WhitTAKER, Good Faith ... cit., p. 547.

255 Cf. R. Zimmermann e S. WhitTAKer, Good Faith... cit., p. 548. Em tradução livre: “investido como resultado".

${ }^{256}$ Cf. Good Faith... cit., p. 535-536 e 548-549.

257 “Art. 1.134 - Les conventions légalement formées tiennent lieu de loi à ceux qui les ont faites. Elles ne peuvent être révoquées que de leur consentement mutuel, ou pour les causes que la loi autorise.

Elles doivent être exécutées de bonne foi". Em tradução livre: "Art. 1.134 - As convenções legalmente formadas têm força de lei sobre aqueles que as fizeram. Elas não podem ser revogadas salvo por consentimento mútuo ou pelas causas que a Lei autorize. Elas devem ser executadas de boa-fé". 
admitem certa dificuldade de estabelecer critérios que possam demonstrar, ainda que em teoria, quando se configura o abuso na denúncia do contrato.

Parece mesmo inequívoco que não há na legislação francesa qualquer dispositivo análogo ao art. 473, par. ún., do Código Civil, o qual, como já frisado, estipula critério específico, qual seja a existência de investimentos.

Já sob o ponto de vista do ordenamento italiano, em ambas as hipóteses acima descritas, a análise das questões também está resguardada a partir do cotejo entre o exercido do direito de resilição e a boa-fé. A pesquisa mais aprofundada revela inclusive o critério da compatibilização dos investimentos com o aviso prévio ${ }^{258}$.

$\mathrm{Na}$ Inglaterra, contudo, como antes mencionado, a resposta foi reticente ao considerar a possibilidade de reconhecimento de abusividade da denúncia. A remição ao contrato relacional ou a uma obrigação implícita do contrato de longa duração foi categoricamente inadmitida ${ }^{259}$.

De mais a mais, considerando o que foi até aqui visto, acerca de estudos sobre uma obrigação perene e contínua de renovação e, ainda, os relatos sobre as hipotéticas soluções aos problemas propostos por REINHARD ZIMMERMANN e SIMON WHITTAKER, pode-se afirmar que há em diferentes ordenamentos uma convergência no que toca às relações de longa duração.

Por exemplo, a resposta noticiada pelos estudiosos alemães, austríacos e franceses, os quais traçaram uma significativa distinção na hipótese de renovação automática ou expressa, assemelha-se a várias posições oferecidas neste estudo. Sem dúvidas, quando as partes, de fato, aproximam-se e realizam uma renovação expressa do contrato, há muito mais espaço para a "compreensão comum" do que em casos de renovação automática.

\footnotetext{
${ }^{258}$ V. Good Faith ... cit., p. 538: "A typical example of such a breach which is discussed by Italian scholars may be found in the situation where a party to a contract who wishes to terminate it induces the other party to make investments which cannot be amortized within the time-span of the contract. In these circumstances, the aggrieved party may obtain damages equal to its reliance interest in relation to the contract". Em tradução livre: "Um exemplo típico de uma tal violação que é discutido pelos estudiosos italianos pode ser encontrados na situação em que uma parte num contrato que pretenda a cessação induz à outra parte para fazer investimentos que não podem ser amortizados no período de tempo do contrato. Nestas circunstâncias, a parte prejudicada pode obter uma indenização igual ao seu interesse negativo em relação ao contrato".

${ }^{259}$ Cf. Good Faith... cit., p. 539.
} 
No que toca ao pressuposto fático da norma do art. 473, par. ún., as elucidações a respeito dos sistemas italiano e austríaco também aludiram à necessidade de investimentos da contraparte.

Ademais, em que pese a informação fornecida pelos doutrinadores britânicos sobre a inadmissão do denominado contrato relacional, resta claro que, em países da tradição do common law, principalmente nos Estados Unidos, a ingerência do princípio da boa-fé, especialmente nas relações de longa duração, é, com efeito, traduzida pela abordagem relacional do contrato. As proposições decorrentes de tal teoria assemelham-se sobremaneira ao que se viu quanto à eficácia da alteração do comportamento das partes balizado pela boa-fé.

Tal constatação inclusive ratifica o que já havia sido adiantado por MACEDO JR. ao asseverar, com precisão, que a abordagem relacional prescreve uma revalorização e ampliação da cláusula geral da boa-fée ${ }^{260}$; ou, ainda, por PAULO ARAUJO, ao enfatizar que a abordagem relacional não inovava no paradigma contratual contemporâneo aos olhos dos estudiosos mais atentos ${ }^{261}$.

\section{Seção IV - Custos de transação obstantes da renovação expressa do contrato}

A despeito das ideias até aqui foram apresentadas, ainda é preciso aprofundar o estudo, pois a ideia de "compreensão comum" das declarações negociais segundo um standard de conduta legitimado pela boa-fé objetiva torna-se muitas vezes insuficiente para que a melhor solução, consensual ou judicial, seja encontrada.

Considerem-se as relações de longa duração nas quais o enunciado contratual é alterado pela conduta das partes. Pode então surgir a seguinte indagação: em certo momento, as partes não deveriam ter renovado/alterado as disposições contratuais? E ainda, se as disposições não estavam claras (se a "compreensão comum" não era evidente), certos investimentos frustrados não decorreriam do risco inerente a tal contrato?

\footnotetext{
${ }^{260}$ Contratos... cit., p. 286.

${ }^{261}$ Prorrogação... cit., p. 98.
} 
Estas questões afloram absolutamente pertinentes, sendo que as respectivas respostas dependem de uma sucessiva indagação muito mais genérica: a renovação/alteração expressa das disposições contratuais teria sido eficiente?

O Teorema de Coase auxilia elucidar tal interrogação. Como antes observado, num cenário ideal, livre de custos de transação, as trocas entre contratantes serão sempre eficientes. Assim, nesse ambiente hipotético, toda e qualquer alteração no comportamento das partes pode ser imediatamente incorporada ao contrato (sem qualquer onerosidade).

Nesse cenário, imagine-se que em meio a uma relação contratual duradoura, os contratantes, a cada 15 dias, aproximam-se e revisam o contrato de forma geral, estipulando disposições claras a fim de incorporar toda e qualquer instabilidade que afete o contrato: quanto ao volume pactuado, prazo de cumprimento, forma de pagamento, investimentos a serem realizados, etc.

Jamais, portanto, a denúncia será abusiva, pois o aviso prévio foi revisto tantas vezes quantas necessárias, de modo que, independentemente das alterações do comportamento das partes, sempre havia previsão convergente com os investimentos aportados de parte a parte.

Ocorre que, na realidade, o aditamento expresso do contrato dificilmente será realizado sem a incidência de certos custos de transação. Em meio a um cenário de alta complexidade, o custo para a incorporação de certo contratempo ou contingência ao instrumento contratual pode ser excessivamente dispendioso e, portanto, ineficiente (leiase: desinteressante para ambas as partes).

Na prática, muitas vezes a aproximação para eventualmente reavaliar o aviso prévio em caso de resilição unilateral, por decorrência de mudanças no ambiente contratual, será demasiadamente custoso a ponto de não interessar nenhuma das partes.

Adicione-se a esse aspecto a dificuldade em alterar uma disposição contratual de forma isolada. É inerente a qualquer contratante, quando enfrenta uma situação de alteração do contrato, procurar adequar a relação como um todo e não simplesmente no que se refere ao aviso prévio em caso de ruptura unilateral. 
Daí, em caso de litígio envolvendo o diferimento do aviso prévio, ser recomendável a investigação sobre a possibilidade ou não de alteração expressa das disposições contratuais.

Por exemplo, cogite-se uma situação em que os investimentos, supostamente aptos a implicar a sanção de prorrogação, decorrem única e exclusivamente de uma simples cláusula contratual (v. g. "o fornecedor arcará com as despesas de 2 seguranças armados durante as entregas noturnas"). Numa situação desta, o intérprete pode estimar que não existiam custos de transação impeditivos da modificação da disposição contratual.

Logo, se, na verdade, o fornecedor arcava com os custos de 10 seguranças, seria justo compreender que tal modificação deveria ter sido comunicada à contraparte. Não é crível vislumbrar custos de transação impeditivos desta alteração contratual (ressalve-se que, se restar provado que a contraparte sabia, ou deveria saber, do aumento do número de seguranças, pouco importa se o fornecedor não prestou informações adequadas - o investimento proporcional à "compreensão comum" sempre deve ser tutelado).

Em sentido oposto, imagine-se uma situação cujos investimentos decorram de uma série de disposições contratuais e não podem ser pormenorizados de forma simples. Há situações, inclusive, em que o mero cálculo dos investimentos aportados pode demandar altos custos. Em uma ocasião como essa, o juiz deve compreender que a nenhuma das partes interessava a renovação expressa do vínculo, pela evidência de altos custos para tanto.

Desta constatação, conclui-se que muitas vezes ambas as partes preferem manter relação contratual sem revisão (ou, ao menos, toleram tal situação), sob pena de incorrer em custos indesejados, mergulhando numa situação de incompletude contratual.

Assim, é curial perceber que o aviso prévio estipulado em contrato, se incompatível com investimentos empreendidos por mudanças tácitas no comportamento das partes, não pode ser reputado justo, simplesmente porque à parte prejudicada cabia revê-lo e, se assim não o fez, assumiu o risco de uma denúncia unilateral da contraparte. 
Se ambas as partes condescenderam com a situação, foi porque assim desejaram. Presume-se que a ausência de renovação expressa do contrato decorre do interesse mútuo das partes.

Esta conclusão, ainda, coaduna-se com o que foi afirmado sobre a chamada incompletude contratual. Se a alteração expressa do enunciado contratual foi obstada pelos custos necessários a ambas as partes, é porque os contratantes possuíam interesse em um contrato incompleto, ainda que tal interesse tenha sido manifestado tacitamente.

\section{Seção V - Ineficiência da multa contratual e o aviso prévio.}

Outra situação que deve ser analisada neste estudo é aquela observada frequentemente nas relações com prazo determinado, mas com resilição unilateral convencionada contra o pagamento de multa contratual. Ainda assim, mesmo com o consenso anterior sobre a multa, poderá haver possibilidade de prorrogação do aviso prévio.

Posto isso, é válida a elucidação de um exemplo concreto: a fornecedora A contrata a distribuidora B para distribuição de produtos inovadores no mercado.

As disposições contratuais, entretanto, vão muito além de uma mera distribuição de produtos. A distribuidora $\mathrm{B}$ obriga-se não só à obrigação principal, mas também a coordenar eventos para divulgação do produto, à contratação de especialistas para atenderem a estes eventos e à organização da distribuição de material publicitário sobre o produto ${ }^{262}$.

Convenciona-se, ademais, que a remuneração da distribuidora B será atrelada a um percentual sobre as vendas do produto. No mais, ambas as partes podem resilir o contrato imotivadamente, contra o pagamento de multa calculada pelo valor somado da média dos últimos seis meses de remuneração da distribuidora B. Observe-se que, neste caso, sequer foi convencionado o aviso prévio, mas apenas a previsão de multa contratual na hipótese de ruptura contratual.

\footnotetext{
262 O que neste exemplo simboliza os custos de transação. Na verdade, os custos de transação incidem não exclusivamente em decorrência de obrigações ulteriores, como neste exemplo.
} 
$\mathrm{Na}$ contratação, as partes esperavam uma evolução linear das vendas do produto. Se assim fosse, dificilmente a multa seria reputada injusta, muito menos haveria "bons" ou "maus" momentos para resilir o contrato, já que a multa estaria condicionada à remuneração média dos últimos seis meses.

Ocorre que, para a surpresa dos contratantes, no primeiro ano da relação contratual, basicamente não foram distribuídos produtos, a despeito de terem sido realizados vários eventos de divulgação, incorrendo o distribuidor em vários custos. No segundo ano, depois de um início não muito diferente, houve um vertiginoso crescimento de vendas.

Exatos seis meses após o início do aumento de vendas, contudo, a fornecedora A notifica a distribuidora $\mathrm{B}$ de sua intenção de resilir, esclarecendo que prontamente será paga a multa compensatória.

Neste cenário, a distribuidora B revolta-se contra a conduta da fornecedora A, com a convicção de que não aproveitou eficientemente aquilo que esperava do contrato, eis que as vendas estavam em expansão e o vínculo ainda perduraria por mais de um ano.

A fornecedora A, por sua vez, em nada descumpriu as disposições enunciadas no contrato e do momento da ruptura em diante, está livre para dispor de seus produtos, já divulgados ao mercado, da forma que preferir.

A análise econômica do direito também pode servir como importante auxílio para caracterização de abuso de direito.

Em contratos que estipulam a resilição unilateral condicionada a pagamento de multa compensatória, é interessante a avaliação sob o prisma do "paradoxo da indenização”. A compreensão de quais incentivos irradiam da disposição contratual, é potencialmente fator decisivo para o intérprete.

Se restar caracterizado que a multa apontava muito mais na direção de certo denunciante, a conduta pode ser interpretada de modo distinto, ou seja, evidências de que a multa não criará obstáculos à saída de uma parte, mas, em compensação, não absorverá os investimentos (ou os custos de transação) empreendidos pela contraparte, pode levar ao reconhecimento da abusividade da conduta. 
É claro que estas ponderações não são irrefutáveis e nada impede que o baixo incentivo decorrente da multa convencionada advenha de uma "má contratação". A contraparte, se é este o caso, nada poderia pleitear.

Ocorre que com base, por exemplo, nas contribuições de FERNANDO ARAÚJO ${ }^{263}$ quando são ilustradas as benesses da tutela de um sistema de "responsabilidade decrescente em contratos duradouros", como analisado, a noção de "má contratação" pode ser repensada.

Quanto ao exemplo acima exposto, alvitra-se a impossibilidade ex ante de quantificar eficientemente uma multa em contratos de longa duração. Daí reputar a resilição da fornecedora abusiva, pois a multa não estava irradiando os incentivos que dela se esperava, implicando, por isso, oportunismo da denúncia intentada.

Acrescente-se, ainda, que a noção de contratos incompletos precisa também ser considerada.

Nos casos de contratos completos (ou que assim poderiam ter sido celebrados), acordos em que as peculiaridades da relação eram cognoscíveis desde o momento da celebração, a insatisfação quanto a certa multa só pode ser reputada em desfavor da contraparte, e não daquele que resili o contrato da forma previamente convencionada.

Já nas hipóteses em que as partes contrataram pela via incompleta, o surgimento de certo momento em que o ônus de resilir não seja alto não deve servir como abertura a uma conduta oportunista.

Lembre-se que a contratação pela via incompleta pode advir da impossibilidade de se prever uma multa compatível em um momento futuro, ou ainda, pode decorrer da economia dos custos de transação, pois as tratativas pré-contratuais para desvendar os critérios par quantificar perfeitamente a multa contratual seriam tão onerosas que potencialmente obstariam a contratação ou diminuíram de forma indesejada o benefício econômico esperado.

${ }^{263}$ Uma análise... cit., p. 103. 
Nas relações de longa duração, portanto, o intérprete deverá analisar se, quando do momento da resilição unilateral, a multa estava em consonância ou aquém de um desejado equilíbrio eficiente do contrato.

O sopeso da eficiência da multa é, sem dúvida, uma forma de prestígio à análise econômica de direito do modo como adiantado neste trabalho, ou seja, sem desrespeitar o paradigma posto.

O intérprete nada mais fará do que coibir o abuso de direito por incoerência com a boa-fé objetiva ou aos costumes observados no negócio. A novidade é analisar o montante da cláusula penal de forma a compatibilizá-la a um aviso prévio justo, maximizando a eficiência da relação jurídica sem simplesmente deixá-la ser resolvida por eventual demanda a requerer indenização suplementar.

Trata-se de uma indubitável exceção ao princípio do pacta sunt servanda, o que geralmente deve ser balanceado cun granus salis nos denominados contratos de lucro, mas, como se explicou, no que toca ao aviso prévio em contrato de longa duração, a exceção deve ser tolerada por imposição expressa da norma do art. 473, par. ún.

Finalmente, o reconhecimento do desequilíbrio de uma multa contratual em caso de resilição unilateral (a gerar denúncia abusiva do contrato mesmo contra o pagamento da quantia avençada) adquire contornos ainda mais importantes, quando lembrado que, no Brasil, há sensível redução das possibilidades de adequação dos efeitos da cláusula penal, ante um sistema que veda de forma veemente a instituição de penas privadas.

Se admitida a inserção de pena privada, ou ainda caso fosse reconhecida a dupla função da cláusula penal, ou, ao menos, sua modalidade em tom preventivorepressivo $^{264}$, potencialmente, muito mais raros seriam os casos de denúncia abusiva do

${ }^{264}$ Cf. a posição de A. PINTO MonteIRO, Cláusula penal e indemnização, Coimbra, Almedina, 1984, principalmente p. 571-576 sobre as teorias que admitem a dupla função da cláusula penal e p. 671-675, sobre a proposição de PINTO MONTEIRO acerca da superação do modelo de dupla função da cláusula coexistindo antes funções e modalidades distintas da cláusula penal, uma coercitiva e a outra para pré-fixação da indenização. Não existiria dupla função, mas a possibilidade de se convencionar duas cláusulas distintas. 
contrato, pois o estímulo ao adimplemento estaria inserto exatamente nesta parcela adicional do montante convencionado ("pena privada") ${ }^{265}$.

Portanto, em um sistema em que só se admite a previsão de cláusula penal com intuito de estabelecer ex ante a compensação dos danos (“cláusula penal compensatória"), em caso de ainda assim reputar-se ilícita a conduta da parte devedora da multa, haverá duas hipóteses de repúdio à conduta antijurídica: a indenização suplementar se assim tiver sido convencionado, segundo o que prescreve o art. 416, p, único, do Código Civil ou a manutenção do vínculo contratual por certo período de tempo, forte no art. 473, par. ún., do Código Civil.

Deve-se concluir, ante o expendido, que a disciplina da cláusula penal instituída pelo Direito Civil brasileiro coaduna-se perfeitamente com a admissão da prorrogação do aviso prévio em relações de longa duração ainda nas ocasiões em que a resilição unilateral houver sido convencionada contra o pagamento de multa.

${ }^{265}$ V., neste sentido e por todos, O. L. RODRIGUES JR., Natureza, função e modificação da cláusula penal no Direito Civil brasileiro (tese-USP), São Paulo, 2006, p. 348: “1. A cláusula penal, tomada em uma perspectiva do direito civil brasileiro, possui natureza singular, monofuncional, destinada a ressarcir os danos pré-estabelecidos pelas partes em um negócio jurídico. 2. A função punitiva, associada à prevenção geral, não existe no direito brasileiro, ante os controles internos e externos à cláusula. As sanções processuais compulsórias substituíram-se nesse papel, sem que, com isso, tenha-se demonstrado a superioridade dos métodos ad terrorem de indole pública sobre as penas privadas". 


\section{CAPÍTULO 2 - OS “INVESTIMENTOS CONSIDERÁVEIS”}

Foram examinados os critérios possíveis para o diagnóstico do abuso de direito no que toca às relações contratuais de longa duração, ainda que por prazo determinado. Não se pode olvidar, todavia, que intrinsecamente conexa à ideia de prorrogação compulsória dos contratos está a própria premissa fática introduzida pelo art. 473, par. ún., do Código Civil, qual seja a de "investimentos consideráveis".

Como antes frisado, nem todas declarações negociais exaradas de parte a parte podem implementar o pressuposto fático daquela norma, mas tão somente aquelas que: $i$ ) propiciam ("cooperam para") o investimento; e ii) as que, de fato, realizam o investimento.

Claramente, como registrado em alguns estudos pontuais ${ }^{266}$, as expressões empregadas na redação do aludido dispositivo legal não são precisas ou específicas e, assim, reclamam exegese mais acurada, que agora passa a ser o objeto da presente pesquisa.

A análise dos investimentos deve ser sempre sopesada junto dos demais critérios já especificados no presente trabalho. A abusividade da conduta não decorre unicamente dos “investimentos consideráveis", mas a prorrogação compulsória, esta sim. só pode ser imposta se evidenciados os investimentos da contraparte.

Não fosse assim, haveria inequívoco descumprimento do regrado no art. 473, par. ún., do Código Civil. Inevitavelmente, caso ocorra abuso de direito na resilição contratual, mas sem a presença de "investimentos consideráveis", só a responsabilidade civil pode ser imputada.

\footnotetext{
${ }^{266} \mathrm{Cf}$. A. FERRIANI, Os limites da resilição unilateral do contrato e o art. 473 do CC, in Migalhas, 15 de fevereiro de 2012. disponível em http://www.migalhas.com.br/Civilizalhas/ - acesso em 6 de junho de 2013: "A vagueza do texto tem o objetivo de deixar nas mãos dos juízes a ingrata tarefa de investigar o caso concreto, por meio de complexas e duvidosas perícias, e fazer justiça. Porém, a sua aplicação prática faz surgir muitas dúvidas $e$ questionamentos, a começar pela tentativa de suprimir o risco inerente a todo tipo de negócio." e P. C. L.P. BARROS, A resilição unilateral do contrato de distribuição, disponível em http://www.uj.com.br - acesso em 17 de setembro de 2011. No TJSP, em acórdão de relatoria do Desembargador RUI CASCALDI, foi determinada a prorrogação do vínculo contratual, não obstante tenha sido reconhecida a dificuldade para apurar os critérios traçados na apontada norma legal: "Existência de prova inequivoca de que a contratante fez investimentos consideráveis em função da relação contratual operada em função da relação contratual até então existente - Prazo de rescisão que, assim, se mostra desarrazoado - Possibilidade de dilatação Artigo 473, parágrafo único, do Novo Código Civil, aplicável ao caso - Inexistência de prova, por ora, do volume de investimentos feitos pela contratante - Dilação que assim se defere até prolação da sentença de primeiro grau, ficando, a critério do juízo 'a quo' estendê-lo, ou não, diante dos argumentos da parte contrária, ainda não citada, e da prova realizada" (Agr. Instr. n. 7.148.853-4).
} 
Ressalte-se, também, que o referido dispositivo sub examine qualifica a noção de investimento em dois momentos. Primeiramente, para estabelecer a premissa fática que atenta para a postergação do momento de eficácia da denúncia, exige-se que os investimentos devam ser "consideráveis". Já na parte final do enunciado, determina-se que o prazo de prorrogação deve ser compatibilizado "com a natureza e o vulto" dos investimentos.

Sobre a verba legal em apreço, ADRIANO FERRIANI escreveu interessante ensaio, suscitando uma série de problemas pertinentes. Vale a transcrição do seguinte trecho do citado estudo:

"Além disso, outras indagações, para reflexão, podem ser feitas: Se o investimento 'vultoso' de uma das partes foi feito para atender também outros clientes, aplica-se tal norma? E se o investimento 'vultoso' foi feito contrariando determinação expressa do próprio contrato? E se a parte que pretende a resilição é forçada a fazê-lo para cortar despesas, em face do cenário externo e de seu ramo de atividade? O período razoável, ou compatível com o vulto dos investimentos, precisa levar em consideração também o lucro esperado, ou apenas os investimentos feitos para ao menos 'zerar' a operação?"267

Importa ressaltar que o equacionamento destas indagações se fazem oportunas em prol de uma melhor sistematização do art. 473, par. ún., do Código Civil.

Ocorre que antes de sugerir algumas conclusões sobre os atributos dos investimentos que devem ser reputados significativos (ou na dicção da lei: “consideráveis") para se cogitar de prorrogação compulsória, torna-se imprescindível a análise dos chamados interesses contratuais e sua divisão em positivos e negativos ${ }^{268}$.

Com efeito, o interesse contratual positivo é aquele por meio do qual o credor espera que o devedor adimplirá sua obrigação para satisfação de seu interesse objetivo na prestação. Já o interesse negativo diz respeito à confiança do devedor ou do credor no outro contratante, sujeitando-se a situações ou realizando investimentos na crença de que

267 Os limites... cit.

${ }^{268}$ V. por todos, P. M. PINTO, Interesse contratual negativo e interesse contratual positivo, vs. 1 e 2 , Coimbra, Coimbra Ed., 2008. 
certo sacrifício será compensado em momento futuro. O interesse negativo, portanto, está atrelado à confiança no adimplemento da relação contratual.

Sendo assim, propõe-se a divisão deste capítulo primeiro para traçar a distinção entre discernir interesses positivos e negativos dos contratantes, para, em seguida, enfrentar determinados critérios, decorrentes, em particular, da análise econômica, para demonstrar quais investimentos devem ou não ser tutelados. A final, examinadas tais coordenadas, pretende-se solucionar, entre outros, os problemas acima apresentados.

\section{Seção I - Interesse contratual positivo e interesse contratual negativo}

O interesse contratual positivo é aquele pelo qual certo contratante toma todas as providências diretamente necessárias para o devido cumprimento do contrato, "desde as despesas com o contrato, os gastos tornados inúteis para a celebração do negócio e preparação do cumprimento, a oneração com deveres de ressarcir terceiros (por exemplo, clientes), o lucro cessante do negócio, bem como outros danos concomitantes ou consequenciais, e, por exemplo, as vantagens concretas que se teria retirado da prestação (tal como o uso da coisa) recebida"269.

Sendo assim, a frustração do interesse positivo produz prejuízo patrimonial convencional decorrente do inadimplemento contratual ${ }^{270}$. Não há maiores discussões sobre sua natureza e, apesar de normalmente ser lembrada a ausência de previsão legal, PAUlo Mota PINTO pondera que ele pode ser facilmente deduzido dos textos legislativos que regram a responsabilidade contratual (arts. $798^{\circ}$ cc. $562^{\circ}$ e segs. do Código Civil português) $)^{271}$.

\footnotetext{
${ }^{269}$ P. M. PINTO, Interesse... cit, p. 1.474.

${ }^{270}$ Cf. P. M. PINTO, Interesse... cit., p. 1474: "O prejuízo para o credor corresponde, pois, ao interesse contratual positivo, como 'aquele que resultaria para o credor do cumprimento curial do contrato', tratando-se, como se referiu, do 'interesse no cumprimento', a que corresponde o dano que surgiu por causa do não cumprimento ou do cumprimento defeituoso ('dano de não cumprimento') '.

${ }^{271}$ Interesse... cit, p. 1.474.
} 
O interesse contratual negativo, a seu turno, consolidou-se na dogmática há muito menos tempo ${ }^{272}$.

No sistema do common law, há possibilidade de o lesado optar entre a indenização pelo interesse no adimplemento (expectation interest) e o interesse na confiança (reliance interest). A indenização pelo reliance interest engloba as despesas realizadas ou custos desembolsados, "o que se pode revestir de utilidade para o credor quando não conseguir, ou for mais difícil, provar o montante do interesse no cumprimento, por exemplo, quanto aos lucros cessantes"273.

A responsabilidade pela confiança, ou seja, aquela derivada dos danos causados por frustração do interesse contratual negativo já foi defendida em hipóteses de difícil quantificação de lucros cessantes. Prefere-se calcular a indenização pela quantificação de amplas despesas derivadas do contrato, do que cogitar do cálculo de lucros cessantes.

PaUlo Mota PinTo, no mais, põe em dúvida a própria base de toda a teoria, insinuando ser possível reparar danos derivados da confiança do contratante com o pagamento de indenização pelo interesse positivo ${ }^{274}$, até porque o sistema português de Direito Civil não recepcionou a possibilidade de reparação pelo interesse negativo ${ }^{275}$.

\footnotetext{
${ }^{272}$ Cf. P. M. PINTO, Interesse... cit., p. 1: “A vida do interesse contratual negativo não foi fácil - noção incompreendida, rejeitada como construção artificial ou impossível de provar, combatida pelos declarativistas como pelos voluntaristas mais extremos, obteve, porém, consagração legal e consolidou-se na dogmática, acompanhando, numa primeira fase, a expansão (aparentemente sem limites) da doutrina da culpa in contrahendo. A sua ligação à ideia de protecção da confiança - 'interesse na confiança' ou 'dano a confiança' são outras designações que passou a receber desde o início do século XX - manteve a noção no centro do debate teórico, que no direito continental, quer no common law, onde também foi objecto de discussão (embora sobretudo a propósito da responsabilidade pelo não cumprimento). À distinção abriu-se, ainda, a partir do momento em que se passou a propor uma autónoma 'reponsabilidade pela confiança' $-e$ não já apenas, portanto, no quadro da formação do contrato -, todo o problema da articulação das consequências jurídicas dessa responsabilidade, distinguindo-se igualmente uma protecção positiva e uma protecção negativa da confiança”.

${ }^{273}$ P. M. PINTO, Interesse... cit., p. 1.544.

${ }^{274}$ P. M. PINTO, Interesse... cit., p. 1.554: "Mas também à questão a saber, já dentro dos quadros de uma 'responsabilidade pela confiança', por que razão a indemnização pela frustração da confiança haveria de traduzir-se aqui numa indemnização pelo interesse negativo (interesse na confiança em relação ao cumprimento), e não numa indemnização pelo interesse positivo no (ou também na confiança depositada em relação ao) cumprimento.".

${ }^{275}$ Interesse... cit., p. 1.554.
} 
Ademais, segundo o referido doutrinador, levando a teoria às últimas instâncias, a indenização por danos derivados diretamente da confiança levaria o credor a uma situação melhor do que aquela em que o contrato houvesse sido cumprido. Os contratantes seriam entre si "segurador forçado" 276.

Diante dessa indesejada circunstância, é preciso tomar a devida cautela para que a defesa da responsabilidade pela confiança não extrapole o "valor do interesse no cumprimento, 277 .

A reparação do interesse negativo não teria sido recepcionada no ordenamento português ante a ausência de opção do credor em dispor do "direito de resolução" ou da reparação civil. Reconhecido o inadimplemento do contrato, a consequência única é a indenização ${ }^{278}$.

Fosse possível a escolha do credor, a resolução do contrato justificaria a indenização pelos danos derivados da confiança (do interesse negativo), ao passo que a manutenção do contrato (execução específica), uma vez frustrada, acarretaria indenização pelo interesse positivo. É por isso que PAULO MOTA PINTO é enfático ao discorrer sobre a distinção entre a indenização em caso de manutenção do contrato e nas hipóteses de resolução deste.

\section{Destaque-se o arremate de PAUlo Mota PinTo:}

“Apesar de o tema não ser muito tratado, afigura-se que (segundo a concepção dominante, que não é a nossa), nos casos de não cumprimento só existe direito a uma indenização pelo interesse negativo se o lesado dispuser de um direito de resolução do contrato e o exercercaso em que, aliás, ficaria mesmo, também segundo a posição dominante, limitado a uma tal indemnização, não podendo exigir o ressarcimento do interesse no cumprimento. Já no caso de manutenção do contrato o credor ficaria limitado ao seu interesse positivo ou no cumprimento, não dispondo de qualquer direito de escolha entre medidas de indemnização

\footnotetext{
${ }^{276}$ P. M. PINTO, Interesse... cit., p. 1.548.

${ }^{277}$ P. M. PINTO, Interesse... cit., 1.549.

278 Cf. art. $798^{\circ}$ do Código Civil português: "O devedor que falta culposamente ao cumprimento da obrigação torna-se responsável pelo prejuízo que causa ao credor".
} 
correspondentes ao interesse no cumprimento e ao interesse (negativo) na confiança. ,279

Em suma, a doutrina que defende a tutela dos danos advindos do interesse negativo contratual assim o faz em hipótese de resolução do contrato. Não há se falar em reparação do interesse negativo se o contrato for mantido ${ }^{280}$.

Como não mais subsiste o vínculo contratual, é devida a indenização de forma abrangente, englobando as despesas diretas incorridas e também todos os custos apurados, tão somente porque a parte confiou no adimplemento do contrato. O credor estará, sem dúvida, integralmente ressarcido e, sem a necessidade do cálculo dos lucros cessantes, os quais poderão ensejar injustiça tanto ao credor quanto ao devedor em decorrência da substancial dificuldade de sua respectiva apuração mormente nas relações de longa duração.

Realmente, como se verá adiante, uma das vantagens da regra do art. 473, par. ún., é exatamente a de permitir àquele que investiu beneficiar-se do resultado de forma real, afastando-se da solução do litígio o cálculo dos lucros cessantes, os quais podem gerar tanto injustiça ao credor quanto ao devedor.

Tome-se, por exemplo, um contrato de prestação de serviços por uma agência de publicidade. A relação foi entabulada por prazo indeterminado e, além de uma parcela fixa a título de pro labore, o preço da prestação está condicionado ao aumento das vendas do produto.

Imagine-se que, durante anos de intensas campanhas publicitárias, as vendas do produto ( $v . g .:$ uma determinada marca de cerveja) mantiveram-se no mesmo patamar.

Ocorre que, em dado momento, a agência cria uma campanha que altera de forma vertiginosa a posição do produto no mercado, de modo que a relação causal entre a campanha e o aumento resta inequívoca.

Pois bem, meses depois do início das vendas da cerveja, agora em posição de destaque no mercado, a cervejaria comunica à prestadora de serviço a denúncia unilateral

\footnotetext{
${ }^{279}$ Interesse... cit., p. 1.555.

${ }^{280}$ Esta também é a conclusão deste estudo, a que se alcançará mais adiante.
} 
do contrato. Diante de tais circunstâncias submetidas à apreciação judicial, resta evidente a abusividade da conduta.

Neste contexto, há de se convir, uma vez reconhecida a ilicitude da denúncia, o cálculo de lucros cessantes seria dificílimo, pois, provavelmente o único critério para apuração destes seria o volume de vendas do produto desde o advento da nova campanha publicitária. Ocorre que, caso as vendas se revelassem tão somente passageiras, a indenização por lucros cessantes seria potencialmente injusta para o devedor, ao passo que, se o tempo demonstrasse a confirmação da nova colocação de mercado da marca, possivelmente o credor receberia indenização aquém de um valor justo.

Daí, em casos de difícil fixação dos lucros cessantes, melhor do que a tutela do interesse negativo seria a prorrogação compulsória do contrato para cessar o vínculo não de forma abrupta, aproveitando, cada parte, os lucros reais da relação no prazo compatível com os investimentos realizados.

Observe-se que, na ótica do denunciante, a prorrogação compulsória também pode ser mais justa. Na medida em que é difícil justificar a priori se os custos do interesse negativo serão transformados em benefício para a contraparte. Desse modo, eventual indenização poderia ser injusta.

Cumpre ressalvar que a tutela dos interesses negativos, embora criticada por PAUlo MOTA PinTo ${ }^{281}$, que examina várias teorias sobre critérios em busca de um cálculo aproximado, mas justo, de lucros cessantes em casos de resolução ${ }^{282}$, já foi admitida no direito português.

\footnotetext{
281 Interesse... cit., p. 1.699: "Quanto à possibilidade de o credor optar por uma indemnização correspondente ao interesse negativo, ou dano da confiança, em caso de não cumprimento, vimos que está consagrada nalgumas ordens jurídicas (por exemplo, no direito estadunidense) e é defendida por alguma doutrina. Mas salientámos que depara objecções fortes, quer quando a indemnização pelo interesse negativo não estivesse sujeita ao limite do montante do interesse positivo (pois permitiria então transformar o lesante num 'segurador forçado' dos riscos ou cálculos falhados que incorreu o credor lesado), quer em geral, por faltar a 'causalidade de violação do dever', isto é, por pressupor uma alteração do fundamento da responsabilidade. Mesmo então, mantém-se, pois válida a rejeição de um concurso com a indemnização pelo interesse no cumprimento em resultado do não cumprimento do contrato".

${ }^{282}$ V., principalmente, Interesse....cit., p. 1.557-1.570, sobre a “presunção de rentabilidade”, e 1.570-1.583, acerca do cálculo do "desaproveitamento das despesas".
} 
ANTUNES VARELA ${ }^{283}$ ocupou-se da tutela dos interesses contratuais negativos na esfera do ordenamento jurídico lusitano, fornecendo o seguinte exemplo ${ }^{284}$ : num contrato de compra e venda de um piano, o preço também abrange os gastos com o frete da mercadoria. O piano é transportado até o local de entrega indicado pelo comprador, mas não é recebido de maneira peremptória. O devedor, ainda, deixa de pagar o preço.

Ao vendedor do piano, cabe a resolução do contrato, sendo ressarcido das despesas com o transporte; ou a manutenção do contrato, hipótese em que pode pleitear o preço estipulado (contra a entrega da coisa).

Note-se que as despesas incorridas pelo vendedor com o transporte perfazem o interesse negativo do contrato. $\mathrm{O}$ vendedor escolhe se gastará mais ou menos com o frete pela confiança de que o contrato será cumprido. Por isso que, em caso de resolução, tais despesas devem ser ressarcidas.

A mesma lógica não se descortina em caso de manutenção do contrato. Uma vez entregue o piano, o pagamento deve atender ao interesse positivo (aquele que é satisfeito com o adimplemento do contrato). As despesas com o transporte, por sua vez, já estão abarcadas pelo preço.

Contudo, ANTUNES VARELA, secundado por outros estudiosos ${ }^{285}$, assevera que ao credor não é lícito proceder à resolução do contrato e, ainda assim, pleitear a diferença do preço que seria recebida caso o contrato fosse cumprido: “O que ele já não pode fazer, por força de lei, é exigir a restituição do piano (como se negócio fosse resolvido) e reclamar ao mesmo tempo a diferença" ${ }^{\text {286 }}$. O raciocínio é o de que, se o contrato for

\footnotetext{
${ }^{283}$ Das obrigações... v. 2, cit., p. 109-110.

${ }^{284}$ Este exemplo não é precisamente aquele ministrado, embora deveras similar.

285 V., a respeito, M. J. AlmeIDA CostA, Direito das obrigações, 12 ed., Coimbra, Almedina, 2009, p. 1.045: "Independentemente das considerações que possam aduzir-se 'de iure contendo' a favor da doutrina oposta, afigura-se que a nossa lei consagrou a primeira solução. E nem se diga que isso mostra pouco razoável. Na verdade, optando o lesado pela resolução do contrato, seria em substância contraditório que, a mesmo tempo, pedisse a indemnização pelo seu não cumprimento. O que decorre da lógica e coerência dessa opção é colocar o prejudicado na situação em que se encontraria se o contrato não houvesse sido celebrado. Portanto, não só exonerá-lo da obrigação que assumiu ou restituir-lhe a prestação por ele já efectuada, mas também indemnizá-lo do prejuízo que teve pelo facto de celebrar o contrato (dano 'in contrahendo')"; cf., no mesmo sentido, M. A. C. P. CARNEIRO DA FRADA, Teoria da confiança e responsabilidade civil, Coimbra, Almedina, 2007, p. 668-672.
}

${ }^{286}$ Das obrigações... v. 2, cit., p. 110. 
resolvido, o credor deve retornar ao estado anterior (como se o contrato não tivesse sido celebrado).

No mesmo sentido, nos domínios do ordenamento italiano, PIETRO TRIMARCHI, reforçando a vantagem da tutela do interesse negativo em casos de dificuldade no cálculo do lucro cessante, defende a escolha do "contraente insoddisfatto" entre a execução do contrato e a resolução com a devida indenização pelo interesse negativo ${ }^{287}$.

Já no Brasil, a tutela dos interesses contratuais é pacífica. Daí inclusive o estudo dos interesses contratuais não ser investigado a exemplo do que ocorre em outros países.

Voltando-se ao exemplo do inadimplemento da compra e venda do piano, cabe ao credor resolver o contrato ou exigir o cumprimento (art. 475 do Código Civil). Em ambos os casos, entretanto, são devidas perdas e danos, as quais, nos exatos termos do art. 402 do Código Civil, perfazem os danos emergentes e os lucros cessantes, $i$. e., se o vendedor resolver o contrato, deve ser indenizado não só dos gastos com o frete (interesse negativo) como também pela diferença do preço (interesse positivo).

A ótica sob a égide do ordenamento brasileiro é a que mantido ou resolvido o contrato, o credor deve ser levado à posição jurídica em que estaria caso o devedor tivesse adimplido o contrato (e não caso o contrato não houvesse sido celebrado).

Estas ponderações sobre a sistemática brasileira são, em suma, inferidas das lições de RUY Rosado DE AgUiAR JR., o qual, em monografia específica, é categórico ao afirmar que, entre nós, é perfeitamente possível a cumulação da tutela dos interesses contratuais positivos e negativos:

"Realmente, no nosso sistema legislativo, esta é a orientação a seguir. O art. 475 do Código Civil garante ao não-inadimplente o direito de indenização por perdas e danos; "perdas e danos", diz o art. 402 do Código Civil, salvo exceção expressa - que não é o caso - abrangem, além do que efetivamente se perdeu (despesas, preparação para a

${ }^{287}$ Interesse positivo e negativo nella risoluzione del contratto per inadempimento, in Rivista di diritto civile, ano 48, n. 5, Padova, CEDAM, 2002, p. 647 e, em sentido distinto, buscando dar tratamento uniforme à manutenção e à resolução do contrato, a exemplo de PAULO MOTA PINTO, v. F. P. CENINI, Interesse positivo, interesse negativo e incentivi nessa responsabilità contratualle: un'analisi economica e comparata, in Rivista di diritto civile. Suplemento annuale di studi e ricerche, Padova, CEDAM, 2008, p. 223 e 239-242. 
celebração e cumprimento etc.), o que razoavelmente se deixou de lucrar, nessa parcela compreendido também ganho que não se teve em razão do incumprimento e da resolução. Nessas amplas disposições estão inseridas as vantagens que o credor não-inadimplente auferiria com o recebimento da prestação."288

A codificação civil brasileira, acerca dessa matéria, é elogiável pela sua inequívoca coerência. O problema da quantificação dos lucros cessantes (o fundamento mais eloquente dos defensores da tutela do interesse negativo em caso de resolução) parece ser também resolvido pelo próprio art. 402 do Código Civil, quando é estipulado que o lucro cessante é "razoável”.

O vocábulo "razoável" - analogamente ao que será observado em sequencia, sobre a dicção "prazo compatível" -, permite ao intérprete valer-se de quaisquer critérios equitativos para aplicar a norma ao caso concreto $^{289}$. Da própria lei, verifica-se que o legislador brasileiro bem imaginou que o cálculo dos lucros cessantes seria dificílimo (daí um dos principais motivos da mens legis do art. 473, par. ún., do Código Civil - a complexidade no cálculo de lucros cessantes).

Finalmente, resta investigar quais investimentos devem ser considerados como pressuposto do diferimento do aviso prévio. Sem dúvida, são aqueles provenientes do interesse contratual positivo.

Como se afirmou, a proteção aos interesses contratuais negativos só é relevante nos casos de extinção do contrato tanto nos sistemas que apenas permitem a escolha entre a reparação pelos interesses positivos ou negativos, quanto no ordenamento brasileiro, no qual é estabelecida a possibilidade de cumulação.

Uma vez mantido o contrato, inclusive por imposição legal forte no art. 473, par. ún., do Código Civil, devem ser apenas levados em consideração os investimentos

\footnotetext{
${ }^{288}$ Extinção do contrato por incumprimento do devedor - resolução, $2^{\mathrm{a}}$ ed., Rio de Janeiro, AIDE, 2004, p. 269.

${ }^{289}$ Sobre exemplos destes critérios, como já mencionado, v., por todos, PAULO Mota PINTO, Interesse... cit., p. 1.557-1.570, sobre a "presunção de rentabilidade"; e p. 1.570-1.583, acerca do cálculo do "desaproveitamento das despesas".
} 
decorrentes do interesse positivo, pois aqueles advindos do interesse negativo também serão atendidos com o adimplemento do contrato.

A distinção dos interesses contratuais reputa-se de suma relevância na medida em que se os investimentos tuteláveis são somente aqueles derivados do interesse contratual positivo, a proteção está limitada aos investimentos realizados em conexão direta com a relação contratual.

Prorrogado o vínculo contratual, o denunciado auferirá aquilo que esperava também pelos investimentos decorrentes da confiança na manutenção do contrato.

Conclui-se, em resumo, que a distinção entre interesses positivos e negativos do contrato só se faz necessária para as hipóteses de extinção do contrato.

Em outros sistemas jurídicos, a situação é resolvida pela opção ao contratante entre executar forçadamente o contrato ou pleitear reparação pelos investimentos decorrentes da confiança. Já entre nós, o credor pode inclusive escolher resolver o contrato com a reparação pelos gastos advindos da confiança e ainda pelos lucros que auferiria caso o contrato fosse cumprido.

Na hipótese de prorrogação, naturalmente, o contrato deverá ser cumprido. Logo, ao intérprete basta verificar quais foram os investimentos normais empreendidos para a desejada eficiência econômica da relação jurídica (interesse contratual positivo), pois, sendo assim, o cumprimento também prestar-se-á a atender os investimentos realizados por força do contrato (na confiança que ele fosse cumprido - interesse negativo).

Como já também adiantado, a regra do art. 473, par. ún., resolve também eventual dificuldade no cálculo de lucros cessantes, porquanto, durante o aviso prévio, a parte denunciada poderá perceber o lucro real proveniente do negócio, e não o "razoavelmente" presumido.

Esclarecida a natureza dos investimentos que justificam o protraimento do aviso prévio, são oportunas algumas noções sobre os critérios práticos visando a demonstrar como os investimentos justificam o prazo de prorrogação. 


\section{Seção II - Simetria dos investimentos com as declarações negociais}

Uma das formas de discernir se certo investimento deve ou não ser tutelado, ou seja, se a prorrogação compulsória é aplicável ou não ao caso concreto, é verificar a simetria entre o investimento a as declarações negociais das partes, consideradas as noções de alteração do comportamento das partes, obrigação de renovação e custos de transação, ínsitos à renovação expressa do contrato.

Tenha-se presente o seguinte exemplo: uma entidade financeira contrata a prestação de serviços de transportes de valores em carros forte. É convencionada a área de atuação do contrato, v. g., o município de Campinas e respectiva região. São também estipuladas as agências e os horários em que o transportador deverá recolher os numerários. As partes ainda convencionam um prazo de aviso prévio em caso de resilição unilateral.

Pois bem, no desenrolar da relação jurídica, o Banco abre novas agências na região e, ainda, solicita o atendimento em maior número de ocasiões de modo que a prestadora de serviços, por consequência, é obrigada a adquirir novos veículos e ampliar o quadro de empregados.

Em meio a um evidente aumento da prestação de serviços, o contratante comunica a transportadora da resilição unilateral do contrato.

A transportadora demonstra irresignação contra a denúncia do contrato, principalmente porque novos veículos foram adquiridos e novas pessoas foram empregadas, de modo que ainda não foi suficientemente remunerada pelo investimento exigido em decorrência da ampliação da prestação de serviços.

Acrescente-se a tudo, o fato de não ter sido prevista qualquer cláusula específica sobre o aumento da prestação obrigacional, muito menos quanto à aquisição de novos veículos e ampliação do número de empregados.

A resolução de tal problema dependerá da eficácia das declarações negociais emitidas, ou seja, dependendo do cenário em que as respectivas declarações foram enunciadas. 
Pense-se, por exemplo, que a transportadora seja uma multinacional do ramo e presta serviços em inúmeras regiões e países. É certo que a entidade financeira agiu de forma a tornar necessário o incremento de investimentos, (quando ampliou o volume contratado), todavia, não há como justificar a "compreensão comum” entre os contratantes de que novos veículos estavam sendo adquiridos e novos empregados contratados.

$\mathrm{Na}$ ótica do Banco, a transportadora poderia ter correspondido ao aumento de demanda por outros meios que não a aquisição direta de novos veículos e despesas correlatas. Daí, a conclusão de que todo esse investimento não deve ser tutelado, pois, ante o cenário contratual, não era cognoscível a conduta experimentada pela contraparte.

Imagine-se, por outro lado, a mesma situação fática, mas com a transportadora sendo empresa local da região de Campinas. Ora, não se pode admitir que as partes simplesmente desconhecessem completamente o contexto de mercado em que a outra contratante estava inserida. Neste caso, o investimento realizado com a aquisição de novos veículos e ampliação do quadro de pessoal deve certamente justificar eventual diferimento do aviso prévio, pois era absolutamente presumível o fato de que o acréscimo do objeto contratado tornaria indispensável a ampliação da frota e arregimentação de novos prepostos.

Cumpre ainda frisar, acerca destas importantes circunstâncias, que, na primeira situação, a denúncia do contrato não deve, em princípio, ser considerada abusiva, pois se verificou em momento cuja potencialidade de possíveis prejuízos (decorrentes dos investimentos) não era conhecida, nem deveria ser, pela parte denunciante. Já na segunda hipótese, é a própria cognoscibilidade do cenário negocial que conota a abusividade da conduta.

Ressalte-se, ainda, que o mero fato de não haver disposição contratual prevendo eventuais obrigações sobre a aquisição de novos veículos ou até sobre o potencial aumento do volume contratado não deve justificar a priori a responsabilidade do transportador pelos investimentos incorridos, ante ao risco contratual do negócio.

Em contratos de longa duração, como se observou, são latentes as teorias advindas da análise econômica, sobretudo aquelas atinentes à racionalidade limitada dos agentes e à assimetria de informações implicativas de uma desejada (ou, no mínimo, tolerada) incompletude contratual. 
Resta, pois, evidente que alguns contratos são celebrados de forma desalinhada, constando ou faltando disposições que potenciam a produção de futuros conflitos entre as partes. Não é por esta razão, todavia, que a simples ausência de certas disposições contratuais justifique a completa irrelevância de alteração dos comportamentos das partes, as quais não podem ser inferidas diretamente das cláusulas escritas.

Em suma, não se justifica responsabilizar o transportador pela ausência de disposições literais que contemplassem a a possibilidade de aquisição de novos veículos e desembolso de outras despesas se e quando o objeto do contrato fosse dilatado.

Lembre-se, por fim, da última finalidade da análise econômica dos contratos conforme proposição de FERNANDO ARAÚJO ${ }^{290}$ : “6. Fomentar as interdependências duradouras e diminuir a necessidade de estipulações contratuais explícitas".

A proteção dos investimentos simétricos às declarações negociais de modo a prevalecer sobre as disposições contratuais escritas nada mais é, em outras palavras, do que o fomento às interdependências duradouras.

Com essa constatação, volta-se às duas primeiras indagações de ADRIANO FERRIANI: “Se o investimento 'vultoso' de uma das partes foi feito para atender também outros clientes, aplica-se tal norma? E se o investimento 'vultoso' foi feito contrariando determinação expressa do próprio contrato?”291

Se o contrato é, por exemplo, celebrado com cláusula de exclusividade, exigese uma necessária análise diferente do contexto fático. Não obstante, sendo o vínculo exclusivo ou não, só se justifica a prorrogação compulsória se o investimento foi empreendido em consonância com as declarações negociais e se a resilição do contrato impedir o seu aproveitamento.

Se, ademais, a parte denunciada figura em outros contratos similares ao resilido, de modo que o investimento pode ser destinado à outra relação, não há o que justifique a prorrogação do aviso prévio.

\footnotetext{
${ }^{290}$ V. Parte II, Cap. 2, Seção II, item $c$, supra.

${ }^{291}$ V. Parte III, Cap. 2, supra.
} 
Sobre a segunda indagação, certamente também não deve ensejar prorrogação compulsória o investimento realizado em contrariedade à disposição expressa do contrato.

A despeito das ideias aduzidas sobre a dificuldade em prever disposições expressas em contratos de longa duração, nada impede que as partes, por exemplo, indiquem expressamente na avença os investimentos que deverão ser empreendidos para o desejado equilíbrio do contrato.

Se os gastos estavam especificamente discriminados no contrato, só em situações extremas tal investimento poderá legitimar o diferimento do aviso prévio, caso reste provado que o comportamento da parte denunciante estava em completa dissonância de quanto pactuado, a ponto de justificar investimentos ulteriores.

\section{Seção III - Investimentos realizados para contingência de externalidades}

Conforme o que se observou na segunda parte deste trabalho, especialmente com as reflexões resultantes do Teorema de Coase, para aferir investimentos a justificar a aplicabilidade do art. 473, par. ún., do Código Civil, o intérprete também deve-se ater aos custos de transação inerentes às relações contratuais de longa duração.

Nem sempre o cotejo entre as declarações negociais e o contexto fático será suficiente para reconhecer a tutela de certo investimento, pois os contratos de longa duração muitas vezes sofrem ingerência de externalidades.

Ocorre que os custos de transação para a solução desta ou daquela adversidade nem sempre poderão ser qualificados como investimento decorrente do interesse positivo contratual, e, portanto, aptos a ensejar a prorrogação do aviso prévio. O intérprete deve, primordialmente, aferir a qual contratante está afeta a externalidade.

Considere-se um transportador que diminui a quantidade de grãos que cada caminhão carrega. Com o passar do tempo, a rodovia deteriora-se a ponto de serem observadas sensíveis perdas de grãos durante o trajeto.

Pois bem, os custos incorridos para contornar o contratempo com o estado da rodovia constitui adversidade relativa à obrigação do transportador. A externalidade está englobada pelo risco do negócio. 
O investimento desembolsado para contornar o problema da rodovia não se consubstancia como interesse positivo do contrato.

Não fosse assim, toda e qualquer adversidade teria o condão de readequar o equilíbrio econômico do contrato produzindo indesejada insegurança jurídica.

O investimento para internalizar certa externalidade será, entretanto, tutelável nos termos do art. 473, par. ún., se empreendido pela outra parte a qual não estava adstrita à externalidade.

Ainda no mesmo exemplo, imagine-se que o emitente (e destinatário) comprometeu-se a receber as mercadorias no período compreendido entre as $6 \mathrm{hs}$ e $22 \mathrm{hs}$ nos dias úteis. Por decorrência do aumento de viagens, já que o transportador passou a carregar menor quantidade de grãos em cada caminhão, é obrigado a receber a mercadoria em qualquer horário, inclusive fins de semana e feriados, o que restou necessário para que não incorresse em ulteriores prejuízos.

O investimento realizado pelo destinatário, este sim, está adstrito ao interesse positivo no cumprimento no contrato. Tal investimento deve ser tutelado, pois realizado em decorrência de uma externalidade atinente ao outro contratante.

Valendo-se dos ensinamentos relativos aos custos de agência sobre a classificação em custos de monitoramento ou supervisão; com o incentivo ao agente; e derivados das perdas residuais, este exemplo ilustraria aqueles custos para evitar perdas residuais.

Ademais, aqueles tipos de custos para monitoramento do contrato também são cada vez mais frequentes nas relações de longa duração.

Imagine-se um contratante que, por decorrência das normas de governança corporativa, comunica seu contratante que nenhuma das pessoas jurídicas envolvidas na relação contratual pode ser investigada por crimes contra a ordem pública ou que nenhuma das fazendas onde a matéria prima é colhida pode estar envolvida em investigações com suspeita de trabalho escravo.

O contratante é, portanto, obrigado a demonstrar periodicamente auditorias feitas em suas sociedades, coligadas, filiais, fornecedores, etc. Note-se que a externalidade, 
qual seja a exigência pelas normas de governança corporativa, está adstrita ao outro contratante.

Tais circunstâncias exigem altos custos para o constante monitoramento, como a produção de relatórios frequentes ou, muitas vezes, a aquisição de softwares específicos de informações que demandam abastecimento contínuo.

Tais investimentos também devem ser interpretados como decorrentes do interesse contratual positivo, aptos, portanto, a justificar prorrogação do aviso prévio em caso de denúncia abusiva.

Em sendo assim, mais uma indagação de ADRIANO FERRIANI pode ser enfrentada, qual seja: "E se a parte que pretende a resilição é forçada a fazê-lo para cortar despesas, em face do cenário externo e de seu ramo de atividade?".

A ingerência do "cenário externo e seu ramo de atividade" guarda respeito a outras vicissitudes que não aquelas estudadas na presente dissertação. Como já exposto, as externalidades são fatores que influem no contrato e geram consequências, mas sem confundi-las com fatos capazes de gerar substrato para a resolução/revisão do contrato por onerosidade excessiva forte na teoria da imprevisão.

Logo, as alterações do cenário microeconômico não são aptas a justificar investimentos para fins de prorrogação compulsória do contrato.

Todavia, como acima demonstrado, os investimentos decorrentes de fatores exógenos ao contrato justificáveis para manter o desejado equilíbrio econômico, estes sim, são tuteláveis nos termos do art. 473, par. ún., do Código Civil, mas somente se realizados pela parte que não está atrelada à externalidade, uma vez que se a própria parte investir para contornar a adversidade, tal investimento é derivado do risco ordinário do negócio. 


\section{CAPÍTULO 3 - O "PRAZO COMPATÍVEL"}

Como já mencionado diversas vezes no presente trabalho, o aviso prévio, segundo a disciplina do art. 473, par. ún, do Código Civil está condicionado aos investimentos empreendidos pela parte denunciada.

A interpretação da expressão "prazo compatível com a natureza e o vulto dos investimentos" não demanda maior esforço hermenêutico, mas reputa-se necessário observar que o aviso prévio apenas pode ser alargado pelo pressuposto fático contido no dispositivo, qual seja o investimento realizado, sob pena de ofensa à norma posta.

Trata-se de exemplo pelo qual o legislador introduziu no dispositivo o critério para a devida aplicação da norma. Evidencia-se, segundo o alvitre de AGOSTINHO ALVIM, a chamada "equidade legal"292. Os critérios de individualização da norma ao caso concreto foram expressamente previstos na lei.

Tivesse o legislador transferido ao intérprete a possibilidade de revelar a equidade em cada realidade fática, estar-se-ia diante de hipótese de "equidade judicial". A permissão poderia estar contida no texto legal de modo explícito ${ }^{293}$, quando houvesse a inserção do vocábulo equidade ou equitativamente, etc.; ou mesmo, implicitamente, quando é prevista a consideração a gravidade do fato, a circunstância do caso, ou outra peculiaridade excepcional $^{294}$.

Ressalve-se que, para os fins deste estudo, a equidade é admitida como regra de interpretação do texto legal, um postulado normativo e ético de modo a suavizar o rigor legal e adaptá-lo ao caso concreto ${ }^{295}$.

Não se admite a equidade como princípio de direito, uma vez que este constitui norma jurídica emanada do direito pressuposto ou natural ${ }^{296}$; podendo ser explícito

\footnotetext{
${ }^{292}$ V., a respeito, Da equidade, in Revista dos Tribunais. v. 132. ano 1941, p. 3-8, ora in Revista dos Tribunais, v. 797, ano 2002, p. 767-770.

293 A exemplo dos arts. 413 (redução de multa compensatória) e 944, par. ún. (redução da indenização segundo a gravidade da culpa) do Código Civil.

${ }^{294}$ A exemplo do art. 156, par. ún, do Código Civil (estado de perigo não por pessoa da família).

${ }^{295}$ V., a respeito, M. P. CARVALHO FILHO, Indenização por equidade no novo código civil, $2^{\mathrm{a}}$ ed., São Paulo, Atlas, 2003, p. 35.
} 
(positivado ou cláusula geral) ou implícito, sendo compatível com vários graus de concretização e permitindo quaisquer condições fáticas e jurídicas. Comporta, enquanto princípio, uma série de aplicações, podendo ser mitigado por outros princípios de direito. A convivência dos princípios é equilibrada ou conflituosa.

Em contraposição, as regras jurídicas de interpretação/aplicação do direito são estabelecidas para certas hipóteses de atos ou fatos, e não se aplicam a outras. Por mais subjetiva que seja uma regra jurídica, ela é ou não aplicável à espécie. A convivência é antinômica, vale dizer, duas regras contrárias se excluem, ao passo que os princípios devem ser harmonizados com outros princípios, e, mais, com outros valores e interesses. Já ao se aludir a princípios, mesmo no jargão forense, não se cogita da falta de um princípio, mas sim da quebra ou da vulneração do princípio. Um problema de princípios não diz respeito ao seu cumprimento, mas à sua importância, relevância, ponderação, etc. ${ }^{297}$.

É ainda mais claro perceber que a equidade não é um princípio quando se atém à dicção do próprio art. 473, par. ún., do Código Civil. O legislador define que observada a premissa fática (“Se, porém, dada a natureza do contrato, uma das partes houver feito investimentos consideráveis para a sua execução”), a regra jurídica imposta ao intérprete para a eventual alargamento do aviso prévio é a compatibilidade com os investimentos. Este é o critério equitativo. Ele já está previsto na lei. Ao intérprete cabe aplicá-lo. Daí evidenciar-se a denominada "equidade legal".

O legislador poderia ter estipulado maneira diversa estatuindo que em caso de verificação de "investimentos consideráveis", o aviso prévio seria fixado "equitativamente". De tal forma, poderia o intérprete admitir outros critérios equitativos que não unicamente a compatibilidade com os investimentos.

Feita esta explanação, volta-se à derradeira indagação de ADRIANO FERRIANI: "O período razoável, ou compatível com o vulto dos investimentos, precisa levar em

\footnotetext{
${ }^{296}$ A teoria de EROS RoBERTO GRAU, que considera os princípios de direito como sendo emanados do direito pressuposto contraria outras tantas teorias pelas quais os princípios derivam do direito natural. Nos limites desta pesquisa, não é relevante analisar profundamente tal polêmica, sendo certo que a equidade não constitui um princípio de direito, provindo este do direito pressuposto ou do direito natural.

${ }^{297}$ E. R. GRAU Ensaio e discurso sobre a interpretação/aplicação do direito, $4^{\mathrm{a}}$ ed., São Paulo, Malheiros, 2006, p. 192.
} 
consideração também o lucro esperado, ou apenas os investimentos feitos para ao menos 'zerar' a operação?"

De início, frise-se, a exemplo da própria insinuação do autor, não se tratar de "prazo razoável", mas "compatível com a natureza e o vulto dos investimentos". Logo a identificação da grandeza do investimento realizado é bastante para fixar o prazo de prorrogação.

Como salientado da introdução deste capítulo, no ordenamento jurídico brasileiro, tanto em caso de resolução quanto na hipótese de execução específica do contrato, devem ser levados em conta os danos emergentes e os lucros cessantes. Assim, resta indubitável que a prorrogação deverá levar em conta o volume do investimento e o lucro esperado.

Repise-se não ser necessário o cotejo de investimentos porventura realizados pela confiança do contratante (interesse negativo), pois a prorrogação do contrato em simetria aos investimentos diretamente realizados também aproveitará o benefício auferido por decorrência da confiança do contratante.

Nada obstante, em caso de resolução em perdas e danos, ao invés de prorrogação compulsória, os investimentos advindos da confiança deverão ser sopesados na fixação da indenização. Daí outra benesse da prorrogação compulsória, pois permite ao intérprete tão somente o exame dos investimentos diretamente aferíveis da relação contratual.

Destarte, observa-se que a expressão "natureza e vulto dos investimentos" pode ser assim compreendida: "natureza" significa o investimento diretamente decorrente do contrato (advindo, portanto, do interesse contratual positivo) e "vulto" expressa o fato de o prazo respeitar a quantia de fato empreendida e a possibilidade de aproveitamento do lucro esperado.

Ademais, sendo reprovável a determinação de prazo exagerados, a prorrogação compulsória, ainda que decorrente de critérios de difícil aferição, implica preservar o vínculo por certo tempo. Por isto, se substituída a prorrogação compulsória pela reparação em perdas e danos, haveria, outrossim, irretorquível dificuldade na quantificação do quantum debeatur. 
A prorrogação compulsória, neste sentido, não deixa de ser algo informado de maior segurança jurídica, pois é, de certa forma, uma modalidade de execução específica da obrigação. 


\section{CAPÍTULO 4 - CONTRATO COMPULSORIAMENTE PRORROGADO}

Feitas todas as considerações sobre as hipóteses e requisitos para a prorrogação compulsória do contrato, resta, por fim, discorrer sobre a forma de execução das obrigações do contrato prorrogado, principalmente averiguando se haverá distinções na performance, em comparação aos contratos consensualmente em vigor.

Com efeito, para buscar uma análise sistemática, é imperioso ressalvar que no estudo do direito obrigacional, um dos temas mais difíceis é a conceituação do adimplemento. Seja porque a relevância prática é de difícil acepção, ou porque tal figura pouquíssimas vezes foi conceituada em diplomas legislativos, a caracterização do adimplemento se torna uma das questões mais interessantes e atemporais do direito obrigacional.

A doutrina, por vezes, prefere buscar a conceituação pelos seus efeitos ${ }^{298}$, quais sejam a satisfação do interesse do credor; a liberação do devedor e a extinção da obrigação.

Neste contexto, Clóvis do Couto SiLVA, no seu A obrigação como processo, discorreu sobre a "crise da teoria das fontes", pela qual outros fatores devem influir no nascimento e desenvolvimento do vínculo obrigacional, fatores estes que decorrem da cultura e da imersão de modernos códigos no campo social. Concluiu, por fim, que existem outras fontes do vínculo obrigacional não só na lei, mas em princípios, máximas, usos, inclusive revelados pela doutrina e jurisprudência ${ }^{299}$.

No mesmo sentido, pode-se valer da conclusão de RAFAEl PetefFi DA Silva: "para se alcançar o conceito de adimplemento, levando-se em conta o interesse objetivo do credor, ou, melhor dizendo, o fim da obrigação, necessário à apreciação dos ditames sempre mutáveis da boa-fé objetiva 300 .

\footnotetext{
298 V., por todos, F. C. PONTES DE MiRAndA, Tratado de Direito Privado, t. 24, $2^{\text {a }}$ ed., Rio de Janeiro, Borsoi, 1959, p. 71.

${ }^{299}$ C. V. Couto E Silva, A obrigação... cit., p. 80-98.

${ }^{300}$ R. P. SILVA, Teoria do adimplemento e modalidade de inadimplemento, atualizado pelo novo Código Civil, in Revista do Advogado - AASP, ano 22, n. 68, São Paulo, dez./02, p. 140.
} 
Logo, o adimplemento é a realização voluntária ${ }^{301}$ do programa obrigacional sempre em respeito ao princípio da boa-fé objetiva, distinguindo-se das formas de execução forçada ou por terceiro. Sua definição, no entanto, ainda carece de outros requisitos, quais sejam, seus efeitos. Deste modo, o adimplemento é instituto o qual, curiosamente, só é realizado efetivamente quando produz seus devidos efeitos ${ }^{302}$.

Só haverá adimplemento quando verificados três efeitos distintos: a extinção da obrigação; a liberação do devedor e a satisfação do interesse do credor.

Somente com a satisfação do interesse do credor, as outras consequências estarão aptas a produzir sua normal eficácia, ou seja, só há extinção da obrigação e liberação do devedor, quando atendido a satisfação do interesse do credor.

Como assevera ANTUNES VARELA: antes de ser uma causa da extinção, o adimplemento é o meio jurídico predisposto para a satisfação do interesse do credor $^{303}$.

JORGE CESA ${ }^{304}$ lembra que o interesse é objetivo. É observado segundo abstrações. Não se leva em conta o interesse de certo credor, mas qualquer um que, a partir do padrão social médio, estaria, em tese, na mesma posição. Do mesmo modo, é necessária certa abstração quanto à própria satisfação do credor. Cumprida a prestação como previamente acordado, a satisfação é concretizada sem maiores ilações subjetivistas. Daí, falar-se em satisfação do interesse objetivo do credor. FERNANDO NORONHA ${ }^{305}$ lembra que o interesse não é egoísta, e deve ater-se ao escopo econômico/social do próprio negócio.

Com estes esclarecimentos, atente-se que em caso de prorrogação compulsória do contrato, o cumprimento voluntário da obrigação, em verdade, seria derivado do comando judicial.

\footnotetext{
${ }^{301}$ Voluntária em oposição a coação, e não, necessariamente, com animus solvendi.

${ }^{302}$ Cf. F. C. PONTES DE MIRANDA, Tratado... cit., p. 71.

${ }^{303}$ J. M. ANTUNES VARELA, Das obrigações em geral, v. 2, $7^{\text {a }}$ ed., Coimbra, Almedina, 1997, p. 9.

${ }^{304}$ Adimplemento... cit., p. 44.

${ }^{305}$ Direito das obrigações, São Paulo, Saraiva, 2003, p. 20.
} 
No Brasil as normas processuais são absolutamente claras acerca de tal possibilidade, v.g. art. 461 (obrigações de fazer e não fazer) e 461-A (obrigação de entregar coisa certa) do Código de Processo Civil.

Sendo assim, é de indagar-se: a satisfação do interesse do credor obtida apenas por ocasião de medidas judicias coercitivas subverte a natureza do adimplemento? O respeito á boa-fé objetiva deve ser exigido em menor intensidade nos contratos compulsoriamente prorrogados?

Nos limites deste estudo, entende-se que, de modo algum, o cumprimento forçado está consolidado em categoria diversa do adimplemento voluntário.

OTAVIO LUIZ RODRIGUES JR., em estudo sobre o contrato de compra e venda, esclarece que as novas normas processuais aumentam a eficácia do contrato ao conceder maior poder executivo ao juiz ${ }^{306}$. Não há o que legitime abalo à compreensão do fenômeno.

Não há, portanto, como fundamentar distinções no que toca ao adimplemento, esteja o vínculo consensualmente em vigor ou judicialmente prorrogado, só haverá extinção da obrigação e liberação do devedor, se o interesse do credor, objetivamente compreendido, for satisfeito.

Já sob outro aspecto, é imperioso, uma última vez, lembrar que o presente trabalho não está atrelado à alteração das circunstâncias por fato superveniente, muito menos com a possibilidade de execução específica do contrato. A resilição contratual abusiva não deve ser compreendida como hipótese de violação contratual a ensejar as faculdades previstas no art. 475 do Código Civil.

Desta forma, não se pode admitir o poder do intérprete de alterar as disposições contratuais com intuito de recuperar o investimento da contraparte. A apreciação judicial

\footnotetext{
${ }^{306}$ Código Civil comentado, v. 6, t. 1, coord. Alvaro Villaça Azevedo, São Paulo, Atlas, 2008, p. 27-28: “O fato de o CPC permitir a execução de obrigação de dar coisa certa mediante o recurso às sanções pecuniárias compulsórias ou à apreensão judicial não altera o caráter desse negócio jurídico, que continua tipicamente obrigatório e destituído de eficácia real. $O$ art. 461-A, CPC, não criou um novo modo de aquisição de domínio; em verdade, a Reforma do Processo conferiu ao juiz um poder sobrenormal de intervenção no patrimônio do devedor (rectius, executado) para que obtenha, de imediato, o que seria alcancável indiretamente após as marchas e remarchas do processo executivo (citação, penhora e hasta pública). Ao ampliar o poder geral de cautela e de execução do juiz, o legislador reforçou a eficácia da compra e venda, ao tempo em que concedeu ao comprador uma opção diversa da simples resolução do contrato e a consequente conversão da res debita em perdas e danos".
} 
deve, tão somente, limitar-se ao prazo compatível para recuperação dos investimentos segundo as obrigações estabelecidas pelas próprias partes.

Não há fundamento legal ou jurídico para permitir ao juiz intervenção a pondo de estipular como será aperfeiçoado o programa contratual, tal como nas demandas de revisão judicial do contrato. Basta a estipulação de prazo e, se preciso, a imposição de medidas coercitivas.

Esta constatação, no entanto, encontra exceção, haja vista as já mencionadas lições de GIUSEPPE CLERICO ${ }^{307}$ ou Alcides TOMASETTI JR. ${ }^{308}$ A. Se o intérprete estiver diante de um contrato estabelecido pela via incompleta, restando comprovado que no momento da celebração as partes desejavam ou suportavam a incompletude contratual, não restará alternativas se não a de definir a forma, o modo e o prazo necessário para aproveitamento dos investimentos da contraparte, de modo a "completar o contrato".

Finalmente, RicHARD POSNER aduz que a execução forçada e específica do contrato, por excelência, despende mais custos do sistema judiciário, eis que o contrato permanece sub judice até a sua execução completa, ao passo que nas decisões que estipulam a reparação indenizatória o caso é resolvido com "tiro único"309.

Sendo assim, as decisões pela execução específica são excepcionais, por serem preteridas por aquelas que estipulam a condenação para reparar os danos causados pela determinada conduta ilícita.

Nada obstante, como adiantado na introdução deste trabalho, o estudo possui duas finalidades. A primeira na seara negocial ao chamar a atenção para a necessidade da obrigação contratual ex vi legis de compatibilizar o aviso prévio (em caso de denúncia unilateral) com a natureza do contrato e dos investimentos realizados pela outra parte; e a segunda explicitar a possibilidade de tal obrigação ser imposta como sanção ao abuso do direito de resilir.

Deste modo, não se justifica a proposição de que o processo judicial indenizatório será mais eficiente do que o processo judicial para prorrogar




compulsoriamente o vínculo contratual, ainda que com a imposição de medidas coercitivas para tanto. Possivelmente, aliás, a solução judicial pela prorrogação compulsória será digna de maior eficiência eis que deverá ser imposta em sede de juízo cautelar e, uma vez concedida, fatalmente não mais haverá interesse na resolução do conflito em perdas e danos.

No mais, em caso de não concessão da prorrogação compulsória, ainda restará ao outro contratante, se assim desejar, a possibilidade de aforar ação indenizatória, o que já lhe era permitido desde o princípio. 


\section{CONSIDERAÇÕES CONCLUSIVAS}

A presente dissertação, como inicialmente afirmado, teve por escopo examinar novel regra legal, com o precípuo propósito de suscitar o debate acadêmico sobre as suas projeções práticas.

A consciência dessa finalidade, mais do que a tentativa de exaurir a análise de todas as questões relativas ao tema, constitui o motivo que estimulou o seu estudo.

Além das conclusões extraídas durante o desenvolvimento do trabalho, à guisa de considerações finais, podem ainda ser reiteradas e extraídas as seguintes premissas conclusivas:

1. O art. 473, par. ún., do Código Civil positivou obrigação específica pela qual um contratante deve respeitar aviso prévio condizente com os investimentos realizados pela contraparte. A incidência desta importante norma é exclusivamente reservada aos contratos de longa duração.

2. Os contratos de longa de duração por tempo indeterminado, ou, quando houver previsão nos de tempo determinado, podem ser extintos por resilição unilateral mediante exercício de denúncia.

3. É perfeitamente legítima a prorrogação compulsória do contrato se a denúncia for reputada abusiva, independentemente de conduta culposa do denunciante.

4. Segundo os princípios contratuais clássicos e modernos, não há o que justifique a sanção à denúncia abusiva unicamente pela responsabilidade civil. A prorrogação compulsória deve ser admitida como sanção apta a coibir o abuso do direito de resilir.

5. A despeito de ser menos acentuada a ingerência dos princípios sociais contratuais nas relações de lucro, a norma em epígrafe introduz exceção pela qual tais princípios balizam sobremaneira o comportamento das partes no que toca à simetria dos investimentos com o aviso prévio.

6. Nos contratos de longa duração e sua inerente propagação no tempo, existem vicissitudes que, muitas vezes, impedem uma estipulação futura do programa contratual 
incólume de perturbação, uma vez que a racionalidade dos agentes é limitada, as informações são assimétricas e a escassez de recursos é flexível.

7. Por isso que, para diagnosticar se o padrão de conduta, ínsito a certo negócio, foi violado, o intérprete deve analisar se, no momento da denúncia, o estímulo ao adimplemento dos contratantes estava equilibrado, à luz das coordenadas acerca da eficiência da multa em caso de resilição, dos custos de transação necessários para internalização das externalidades e da celebração do contrato com disposições incompletas.

8. Com a ressalva de que as relações de execução diferida não são, tecnicamente, de longa duração, o parágrafo único do art. 473 do Código Civil aplica-se virtualmente a todos os contratos de lucro de longa duração, inclusive àqueles celebrados por adesão, uma vez que a possibilidade de denúncia qualifica-se como elemento particular do negócio e não deve ser interpretada como "direito resultante do negócio", nos termos do art. 424 do Código Civil.

9. Nos contratos existenciais, englobados todos os contratos de consumo, a regra legal em tela é, contudo, inaplicável, porquanto estas relações contratuais independem de investimentos realizados pelo consumidor. Investimentos necessariamente visam ao lucro. Ademais, a tutela de eventuais investimentos empreendidos pelo fornecedor de consumo contrariaria todo o sistema protetivo do consumidor.

10. Nos contratos de lucro, a alteração do comportamento das partes pode exigir investimentos ulteriores em comparação aos que eram esperados quando da celebração do negócio. Só serão tutelados os investimentos quando decorrentes de declarações negociais passíveis de compreensão comum, ainda que esta não seja idêntica à percepção de nenhuma das partes ("significado normativo da declaração").

11. Pela dificuldade de manutenção da estabilidade contratual em contratos de longa duração é, outrossim, reconhecida uma obrigação ínsita de renovação do vínculo contratual, fenômeno que no direito estadunidense ganhou contornos mais latentes pela chamada abordagem relacional do contrato.

12. Para apuração dos “investimentos consideráveis” é tão somente necessário verificar o desembolso diretamente ligado ao contrato, qual seja aquele resultante do interesse contratual positivo. Se, porventura, a parte realizou investimentos outros na 
confiança de que o contrato seria adimplido (interesse negativo), estes também serão aproveitados, uma vez preservado o vínculo contratual. Daí, a desnecessidade de perquirição dos investimentos pelo interesse contratual negativo.

13. Se o vínculo contratual for perturbado por externalidades que, para serem arredadas, reclamam investimentos, só serão tuteláveis os investimentos realizados pela parte a qual não estava adstrita à externalidade. $\mathrm{O}$ investimento realizado pela própria parte deriva do risco contratual e, por isso, não encontra guarida para fins de protraimento do aviso prévio.

14. O art. 473, par. ún., do Código Civil introduziu critério equitativo de aplicação ao caso concreto, especificando que a prorrogação do tempo da avença deve atender a um prazo compatível com o investimento realizado. Por isso que o investimento deve ser reputado como único critério referencial de adequação do prazo de prorrogação. Se, por acaso, a denúncia for reputada abusiva, mas sem a verificação de investimentos empreendidos pela contraparte, só a responsabilidade civil poderá servir como sanção.

15. Prorrogado compulsoriamente o contrato, o ordenamento jurídico predispõe especificamente forma de execução forçada do contrato. Não há o que subverta a noção de adimplemento em contratos compulsoriamente prorrogados, ainda que impostas medidas coercitivas para o seu devido cumprimento. Os princípios contratuais delimitam a conduta das partes como se o vínculo estivesse consensualmente em vigor.

16. Finalmente, o art. 473, par. ún., do Código Civil, não apresenta fundamento normativo a permitir que o juiz-intérprete altere disposições contratuais em demandas, cujo pedido seja a prorrogação compulsória do contrato. Nada obstante, em casos de prorrogação compulsória de contratos incompletos, admite-se a possibilidade de o órgão jurisdicional definir como e por quanto tempo deverá ser aperfeiçoado o programa contratual.

Assim, exibido o resumo das conclusões específicas do presente estudo, resta, a final, enfatizar que o art. 473, par. ún., do Código Civil constitui regra que ainda impõe maior atenção da literatura jurídica pátria.

Dúvida não há de que a paulatina disseminação de estudos sobre a presente temática certamente trará importantes subsídios em prol de uma verdadeira transformação 
no modo de pensar de contratantes que intentam resilir relações contratuais de forma infundada e oportunista, principalmente nas hipóteses em que a ameaça de responsabilidade indenitária não desestimula a conduta abusiva.

Atualmente, a sociedade não está totalmente preparada para lidar com as peculiaridades jurídicas decorrentes da prorrogação dos contratos de longa duração. Reputa-se indispensável a devida atenção à possibilidade de protraimento compulsório do contrato a fim de estimular atuação mais ágil na solução do litígio. O pleito de prorrogação, se iniciado muito tempo após a denúncia abusiva, será inarredavelmente impossível. É preciso celeridade para que a relação contratual ainda possa ser prorrogada quando levada à cognição do juiz.

Finalmente, encerra-se o presente estudo com o intuito de realçar que condutas abusivas em contratos de longa duração podem ser evitadas de forma muito mais eficiente, uma vez aproveitada a potencialidade do art. 473, par. ún, do Código Civil, inclusive quando compreendida a agilidade com que a pretensão de prorrogação deve ser exercida. 


\section{REFERÊNCIAS BIBLIOGRÁFICAS}

Aguiar Jr., Ruy Rosado, Comentários ao novo Código Civil, v. 6, t. 2, coord. Sálvio de Figueiredo Teixeira, Rio de Janeiro, Forense, 2011.

, Extinção do contrato por incumprimento do devedor resolução, $2^{\mathrm{a}}$ ed., Rio de Janeiro, AIDE, 2004.

ALPA, Guido, I principi generali, Milão, Giuffrè, 1993.

Alvim, Agostinho, Da equidade, in Revista dos Tribunais. v. 132. ano 1941, p. 3-8, ora in Revista dos Tribunais, v. 797, ano 2002, p. 767-770.

ARAúJo, Fernando, Introdução à economia, Lisboa, Almedina, 2002.

, Teoria económica do contrato, Coimbra, Almedina, 2007.

, Uma análise econômica dos contratos. Parte I: a abordagem económica, a responsabilidade e a tutela dos interesses contratuais, in Revista de Direito Público da Economia, v. 5, n. 18, Belo Horizonte, jul./set. 2007, p. 69-160.

_, Uma análise económica dos contratos - Parte II: O "paradoxo da indenização", a tutela da confiança, a flexibilização da responsabilidade contratual in Revista de Direito Público da Economia, v. 5, n. 19, Belo Horizonte, abr./jun. 2007, p. $67-$ 123.

, Uma análise económica dos contratos. Parte III: O seguro. O incentivo à eficiência e a separação dos objectivos de prevenção do risco e de reparação do dano, in Revista de Direito Público da Economia, v. 5, n. 20, Belo Horizonte, out./dez. 2007, p. 51-132.

, Uma análise económica dos contratos - última parte: a responsabilidade decrescente em contratos duradouros. Conclusões in Revista de Direito Público da Economia, v. 6, n. 21, Belo Horizonte, out./dez. 2007, pp. 93-119.

ARAúJo, Paulo Dóron Rehder de, Prorrogação compulsória de contratos a prazo pressupostos para sua ocorrência, (Tese-USP), São Paulo, 2011. 
AtiYAh, Patrick Selim, An introduction to the Law of Contract, $5^{\mathrm{a}}$ ed., Oxford, Clarendon Press, 1995.

AZEMA, Jacques, La durée des contrats successifs, Paris, L.G.D.J., 1969.

Azevedo, Antonio Junqueira de, Contrato de distribuição por prazo determinado com cláusula de exclusividade recíproca. Configuração de negócio jurídico per relationem na cláusula de opção de compra dos direitos do distribuidor pela fabricante e conseqüente restrição da respectiva eficácia. Exercício abusivo do direito de compra, equivalente a resilição unilateral, sem a utilização do procedimento pactuado, com violação da boa-fé objetiva, in Novos estudos e pareceres de Direito Privado, São Paulo, Saraiva, 2009, p. 287-311.

, Natureza jurídica do contrato de consórcio (sinalagma direto). Onerosidade excessiva em contrato de consórcio. Resolução parcial do contrato, in Novos estudos e pareceres de Direito Privado, São Paulo, Saraiva, 2009, p. 345-377.

, Relatório brasileiro sobre revisão contratual apresentado para as jornadas brasileiras da Associação Henri Capitant, in Novos estudos e pareceres de Direito Privado, São Paulo, Saraiva, 2009, p. 182-199. , Negócio jurídico - existência, validade e eficácia, $4^{\mathrm{a}}$ ed., São Paulo, Saraiva, 2002. , Negócio jurídico e declaração negocial, São Paulo, Saraiva, 1986.

Barbosa, Rui, Oração aos moços, São Paulo, Papagaio, 2003.

BARros, Paula Cristina Lippi Pereira de, A resilição unilateral do contrato de distribuição, disponível em http://www.uj.com.br - acesso em 17 de setembro de 2011.

BETTI, Emilio, Negozio giuridico, in Novissimo digesto italiano, v. 11, UTET.

CALABresi, Guido, Interprezione giuridica e analisi economica (Prefácio), coords. Guido Alpa, Francesco Pulitini, et.al., trad. it. Francesco Pulitini, Milão, Giuffrè, 1982. 
CAMILO JR., Ruy Pereira, O contrato de distribuição: uma análise à luz da teoria relacional, (Dissertação-USP), São Paulo, 2004.

Carvalho Filho, Milton Paulo, Indenização por equidade no novo código civil, $2^{\mathrm{a}}$ ed., São Paulo, Atlas, 2003.

CEnINI, Francisco Parisi-Marta, Interesse positivo, interesse negativo e incentivi nessa responbalità contratualle: un'analisi economica e comparata, in Rivista di diritto civile. Suplemento annuale di studi e ricerche, Padova, CEDAM, 2008, p. 219-242.

Cesarino, Paula de Oliveira, Contratos relacionais, (Dissertação-Milton Campos), disponível em http://www.mcampos.br/posgraduacao/mestrado/dissertacoes/. - acesso em 17 de outubro de 2011.

CleriCO, Giuseppe, Analisi economica del contratto, Milão, Giuffrè, 2008.

COASE, Ronald, The Problem of Social Costs, in The Journal of Law and Economics, v. 3, 1960, p. 1-44.

CoOTER, Robert e UlLen, Thomas, Law and Economics, $5^{\mathrm{a}}$ ed., trad. port. Luis Marcos Sander e Francisco Araújo da Costa, Porto Alegre, Bookman, 2010.

CordeIro, António Manuel da Rocha Menezes, Da modernização do Direito Civil, v. 1, Coimbra, Almedina, 2004.

, Da boa fé no Direito Civil, v. 2, Coimbra,

Almedina, 1984.

CostA, Mário Júlio Almeida, Direito das obrigações, 12ª ed., Coimbra, Almedina, 2009.

DíAZ-AMBrona BARDAJi, Maria Dolores, El negocio jurídico per relationem en el Codigo Civil, $2^{\mathrm{a}}$ ed., Madrid, UNED, 1994.

DíEz-PicAzo, Luis e Gullón, Antonio, Sistema de derecho civil, v. 2, 9ª Ed., Madrid, Tecnos, 2001.

FERnANDES, Wanderley, e OLIVEIRA, Jonathan Mendes, Contrato preliminar: segurança de contratar, in Fundamentos e princípios dos contratos empresariais, coord. Wanderley Fernandes, São Paulo, Saraiva-FGV, 2007, p. 265-321. 
FERRAZ JR., Tércio Sampaio, Resilição unilateral de relações comerciais de prazo indeterminado e lei de defesa da concorrência, in Caderno de Direito Tributário e finanças públicas, n. 4, São Paulo, Ed. RT, jul-set/1993, p. 270-279.

FERRIANI, Adriano, Os limites da resilição unilateral do contrato e o artigo 473 do CC, in Migalhas, 15 de fevereiro de 2012, disponível em http://www.migalhas.com.br/Civilizalhas/ - acesso em 6 de junho de 2013.

Forgioni, Paula, Contrato de distribuição, 2a ed., São Paulo, Ed. RT, 2008.

FrADA, Manuel António de Castro Portugal Carneiro da, Teoria da confiança $e$ responsabilidade civil, Coimbra, Almedina, 2007.

FrIED, Charles, Contract as Promise - A Theory of Contractual Obligation, Cambridge, Harvard Press, 1981.

GATSI, Jean, Le contrat-cadre, Paris, L.G.D.J., 1996.

Gomide, Alexandre Junqueira, Direito de arrependimento nos contratos, (dissertação-UL), Lisboa, 2009.

Gordon, Robert W., Macaulay, Macneil and the Discovery of Solidarity and Power in Contract Law, in Wisconsin Law Review, 1985 (565), ora in Revista Direito GV, v. 3, n. 1, trad. port. Marcos de Campos Ludwig e José Rodrigo Rodriguez, São Paulo, jan-jun/2007, p 187-202.

GRAU, Eros Roberto, Ensaio e discurso sobre a interpretação/aplicação do direito, $4^{\mathrm{a}}$ ed., São Paulo, Malheiros, 2006.

Henriques, Paulo Alberto Videra Henriques, A desvinculação unilateral ad nutum nos contratos civis de sociedade e de mandato, Coimbra, Coimbra Editora, 2001.

JORDÃO, Eduardo Ferreira, Repensando a teoria do abuso de direito, Salvador, Juspodivm, 2006.

KLEIN, Vinicius, Teorema de Coase, in $O$ que é análise econômica do direito, coords. Maria Clara Pereira Barreto e Vinicius Klein, Belo Horizonte, Fórum, 2011, p. 71-77.

LABORDERIE, Anne-Sophie Lavefve, La pérennité contractuelle, Paris, L.G.D.J., 2005. 
LARENZ, Karl, Metodologia da ciência do direito, $3^{\mathrm{a}}$ ed., trad. port. José Lamego, Lisboa, Fundação Calouste Gulbekian, 1997.

MACEDo JR., Ronaldo Porto, Contratos relacionais e defesa do consumidor, 2.ed., São Paulo, Ed. RT, 2007.

MACNEIL, Ian Roderick, Contracts: Adjustment of Long-Term Economic Relations under Classical, Neoclassical, and Relational Contract Law, in Northwestern University Law Review, v. 72, n. 6, 1978, p. 854-905.

Many Futures of Contracts, in Southern California Law Review, v. 47 , n. 3, 1974, p. 691-816. O novo contrato social (prefácio à edição brasileira), trad. ing. The New Social Contract: An Inquiry Into Modern Contractual Relations, New Haven, Yale University, 1980, trad. port. Alvamar de Campos Andrade Lampranelli, Rio de Janeiro, Elsevier, 2009, p. I-XXXVI.

, The New Social Contract: An Inquiry Into Modern

Contractual Relations, New Haven, Yale University, 1980.

MARÇAl, Sérgio Pinheiro e CURY, Renato José, O comércio eletrônico e o Código de Defesa do Consumidor, in Revista do Advogado - AASP (direito e internet), ano 32, $\mathrm{n}$. 115, São Paulo, abril/2012, p. 136-144.

MARQues, Cláudia Lima, Contratos no Código de Defesa do Consumidor - o novo regime das relações contratuais, 6a ed., São Paulo, Ed. RT, 2011.

Marques, Cláudia Lima e CAVAllazi, Rosângela Lunardelli (coords.), Direitos do consumidor endividado, São Paulo, Ed. RT, 2006.

Martins-Costa, Judith, A boa-fé no Direito Privado, São Paulo, Ed. RT, 1999.

MeKki, Mustapha, L'intérêt général et le contrat - contribution à une étude de le hierárchie des intérêts en droit privé, Paris, L.G.D.J., 2004.

Miranda, Francisco Cavalcanti Pontes de, Tratado de Direito Privado, t. 1, $2^{\mathrm{a}}$ ed., Rio de Janeiro, Borsoi, 1954. 
, Tratado de Direito Privado, t. 24 e 25, $2^{\mathrm{a}}$ ed.,

Rio de Janeiro, Borsoi, 1959.

MonteIro, Antonio Pinto, Cláusula penal e indemnização, Coimbra, Almedina, 1984.

Morsello, Marco Fábio, Contratos existenciais e de lucro. Análise sob a ótica dos princípios contratuais contemporâneos, in Temas relevantes do Direito Civil contemporâneo, coords. Renan Lotufo, Giovanni Nanni e Fernando Martins, São Paulo, Atlas, 2012, p. 292-307.

Mulcahy, Linda e Tilotson, John, Contract Law in Perspective, $4^{\mathrm{a}}$ ed., Londres, Cavendish, 2004.

NegreIROS, Teresa, Teoria do contrato - novos paradigmas, Rio de Janeiro, Renovar, 2002.

Noronha, Fernando, Direito das obrigações, v. 1, São Paulo, Saraiva, 2003.

OPPO, Giorgio, I contratti di durata, in Rivista di diritto comerciale e del diritto genelare dele obbligazioni, v. 41, Milão, F. Villardi, 1943, p. 143-250.

PereIRA, Caio Mário da Silva, Instituições de Direito Civil, v. 3, 12 ed., Rio de Janeiro, Forense, 2007.

PINHEIRO FILHO, Francisco Renato Codevila, Teoria da agência (problema agenteprincipal), in $O$ que é análise econômica do direito, coords. Maria Clara Pereira Barreto e Vinicius Klein, Belo Horizonte, Fórum, 2011, p. 97-108.

PINTO, Paulo Mota, Interesse contratual negativo e interesse contratual positivo, v. 2, Coimbra, Coimbra Editora, 2008.

Posner, Richard A., Economic Analysis of Law, 5 ${ }^{\mathrm{a}}$ ed., Nova York, Aspen Law \& Business, 1998.

REALE, Miguel, Resilição dos contratos por tempo indeterminado, in Questões de Direito Privado, São Paulo, Saraiva, 1997, p. 33-46.

RIBEIRO, Joaquim de Sousa, O problema do contrato - As cláusulas gerais e o princípio da liberdade contratual, Coimbra, Almedina, 1999. 
Rodrigues JR., Otavio Luiz, Natureza, função e modificação da cláusula penal no Direito Civil brasileiro, (Tese-USP), São Paulo, 2006.

Código Civil comentado, v. 6, t. 1, coord. Alvaro Villaça Azevedo, São Paulo, Atlas, 2008.

ROPPO, Vincenzo, Il contratto, Milão, Giuffrè, 2001. Il contratto del duemila, $3^{\mathrm{a}}$ ed., Turim, G. Giappichelli, 2011.

SÁ, Fernando Augusto Cunha de, Abuso do direito, Coimbra, Almedina, 1973 (reimpressão de 1997).

SCHREIBER, Anderson, A proibição de comportamento contraditório, $3^{\mathrm{a}}$ ed., Rio de Janeiro, Renovar, 2012.

Silva, Clóvis Veríssimo do Couto e, A obrigação como processo, 1a (re)edição, São Paulo, FGV, 2006.

SiLva, Jorge Cesa Ferreira da, Adimplemento e extinção das obrigações: comentários aos arts. 304 a 388 do Código Civil, São Paulo, Ed. RT, 2007.

Silva, Rafael Peteffi, Teoria do adimplemento e modalidade de inadimplemento, atualizado pelo novo Código Civil, in Revista do Advogado - AASP, ano 22, n. 68, São Paulo, dez./2002, p. 135-151.

SimÃo, José Fernando, Tempo e Direito Civil - prescrição e decadência, (Tese de Livre Docência-USP), São Paulo, 2011.

SzTAJn, Raquel, Sociedades e contratos incompletos, in Revista da Faculdade de Direito da USP, v. 101, São Paulo, 2006.

TELlES, Inocêncio Galvão, Manual dos contratos em geral, $4^{\mathrm{a}}$ ed., Coimbra, Coimbra Ed., 2010.

TEPEDINO, Gustavo, Novos princípios contratuais e teoria da confiança: a exegese da cláusula to the best knowledge of the sellers, disponível em http://www.tepedino.adv.br/wp/wp-content/uploads/2012/09/biblioteca13.pdf - acesso em 27 de novembro de 2013. 
Theodoro Jr., Humberto, Comentários ao novo Código Civil, v. 3, t. 2, coord. Sálvio de Figueiredo Teixeira, Rio de Janeiro, Forense, 2007.

TOMASETti JR., Alcides, A execução do contrato preliminar, (tese-USP), São Paulo, 1982.

TRIMARCHI, Pietro, Interesse positivo e negativo nella risoluzione del contratto per inadempimento, in Rivista di diritto civile, ano 48, n. 5, Padova, CEDAM, 2002, p. 637649.

VAnZELla, Rafael, $O$ contrato, de Enzo a Vincenzo, in Revista Direito $G V$, v. 1, n.2, São Paulo, jun-dez./2005, p. 221-228.

VAREla, João de Matos Antunes, Das obrigações em geral, v. 2, $7^{\mathrm{a}}$ ed., Coimbra, Almedina, 1997.

VINCENT-JONES, Peter, The reception of Ian Macneil's work on contract in the U.K., in The relational theory of contract: selected works of Ian Macneil, Londres, Sweet \& Maxwell, 2001

ZanetTI, Cristiano de Souza, Direito contratual contemporâneo - a liberdade contratual e sua fragmentação, Rio de Janeiro/São Paulo, Forense/Método, 2008.

Responsabilidade pela ruptura das negociações, São

Paulo, Juarez de Oliveira, 2005.

ZIMMERMANN, Reinhard e WhitTAKer, Simon, Good Faith in European Law, Cambridge, Cambridge University Press, 2004. 